\author{
UNIVERSIDADE DE SÃO PAULO \\ FACULDADE DE FILOSOFIA, LETRAS E CIÊNCIAS HUMANAS \\ DEPARTAMENTO DE LETRAS ORIENTAIS \\ PROGRAMA DE PÓS-GRADUAÇÃO EM \\ LÍNGUA, LITERATURA E CULTURA JAPONESA
}

\title{
MAPEAMENTO DE PREPOSIÇÕES EM NI, DE E WO Uma comparação entre nexos do japonês e do português
}

\author{
Everson Esteques Lemos
}

Dissertação apresentada ao Programa de Pós-Graduação em Língua, Literatura e Cultura Japonesa, do Departamento de Letras Orientais da Faculdade de Filosofia, Letras e Ciências Humanas da Universidade de São Paulo, para obtenção do título de Mestre em Letras.

Orientadora: Profa. Dra. Junko Ota 
UNIVERSIDADE DE SÃO PAULO

FACULDADE DE FILOSOFIA, LETRAS E CIÊNCIAS HUMANAS

DEPARTAMENTO DE LETRAS ORIENTAIS

PROGRAMA DE PÓS-GRADUAÇÃO EM

LÍNGUA, LITERATURA E CULTURA JAPONESA

MAPEAMENTO DE PREPOSIÇÕES EM NI, DE E WO

Uma comparação entre nexos do japonês e do português

Everson Esteques Lemos 


\section{AGRADECIMENTOS}

À minha orientadora, Profa. Dra. Junko Ota, que apesar de seus inúmeros afazeres à frente do Centro de Estudos Japoneses, esteve sempre pronta para uma boa discussão, inclusive com direito às tradicionais — e benfazejas — amenidades da introdução e do encerramento;

Aos professores do Curso de Língua e Literatura Japonesa, que desde a graduação vêm me incentivando e orientando, e a quem devo minha evolução de aprendiz para professor da língua japonesa;

A meus pais, Milton e Marlene, de quem herdo o gosto pelo saber em geral e pelas ciências humanas em particular. 


\title{
Resumo
}

Este trabalho traz uma comparação das posposições de caso NI, DE e WO da língua japonesa com preposições do português, baseada no aparato teórico da semântica cognitiva, e centrada nas estruturas semânticas das posposições de caso desenhadas por Moriyama (2005). Como resultado, elaboramos tabelas com as diversas preposições que podem ser mapeadas em cada uma das várias acepções das posposições estudadas. Cremos que este trabalho traga contribuições para o ensino do japonês a aprendizes lusófonos, bem como para a prática da tradução entre as línguas japonesa e portuguesa.

\begin{abstract}
This work contains a comparison between the Japanese case markers NI, DE and WO, and Portuguese prepositions, based on the theoretic framework of cognitive semantics and centered on semantic structures of Japanese case markers as described by Moriyama (2005). As a result, we have made tables with the several prepositions that can be mapped into each one of the several senses of the case markers studied here. We believe that this work brings contributions for Japanese language teaching to Portuguese-speaking students, as well as to the practice of translation between Japanese and Portuguese.
\end{abstract}

\section{Palavras chave (4):}

posposições de caso do japonês; preposições do português; semântica cognitiva

\section{Keywords (4):}

Japanese case markers; Portuguese prepositions; cognitive semantics 


\section{Sumário}

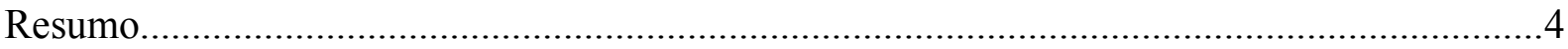

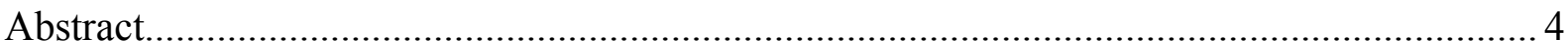

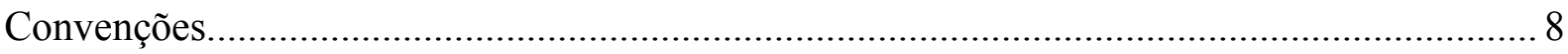

1. Introdução: motivação, objetivo e fundamentação teórica................................................ 10

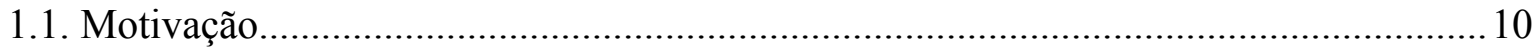

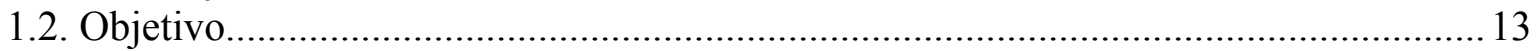

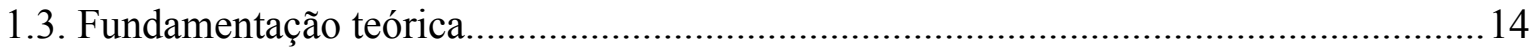

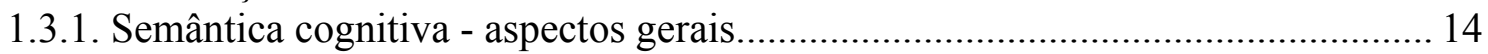

1.3.1.1. Esquemas de imagem e metáforas conceituais.......................................... 14

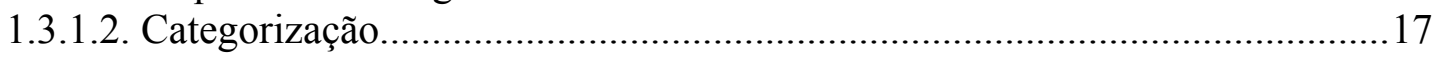

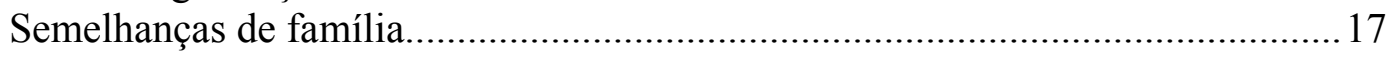

Uma ressalva para o conceito de categorias como redes indefinidas de

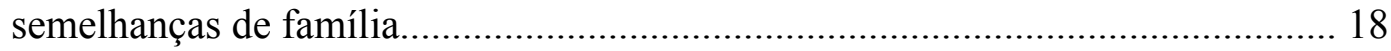

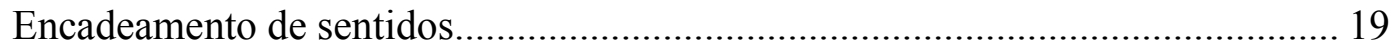

O que é, então, uma estrutura semântica............................................................20

Semântica cognitiva e as posposições de caso..........................................................2 21

1.4. Considerações sobre o objeto de análise e referencial teórico específico.......................26

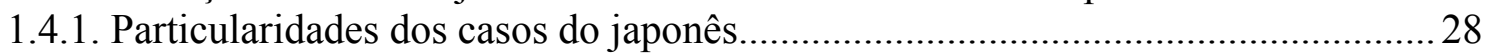

1.4.1.1. Perspectiva processual e perspectiva ontológica em NI.............................. 29

1.4.1.2. Perspectiva objetiva e perspectiva subjetiva em NI...................................32

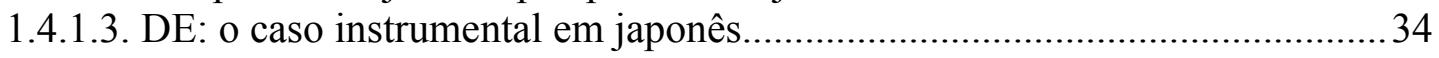

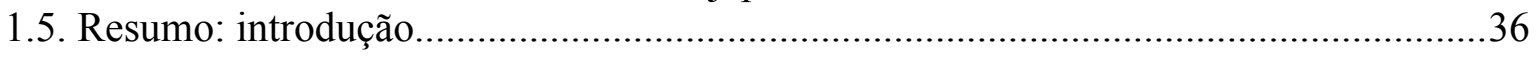

2. As acepções de NI e suas expressões em português........................................................ 38

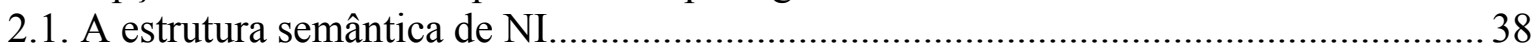

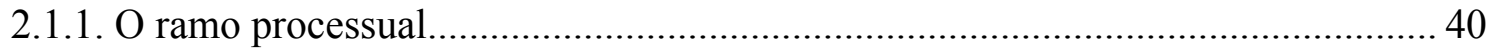

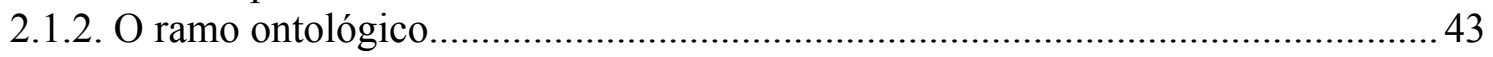

2.1.2.1. Acepções objetivas do ramo ontológico..................................................... 43

2.1.2.2. Acepções subjetivas do ramo ontológico....................................................48

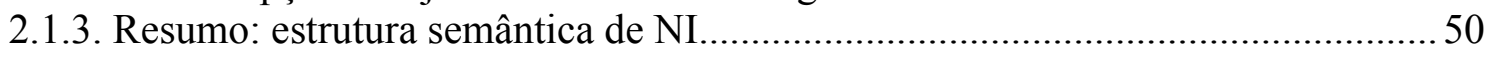

2.2. Mapeamento de preposições do português em NI.....................................................51

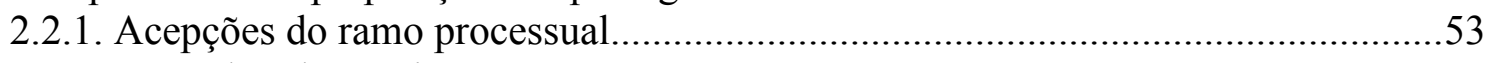

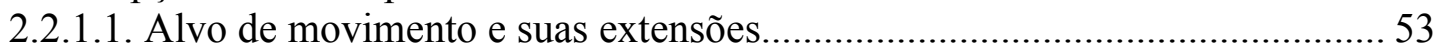

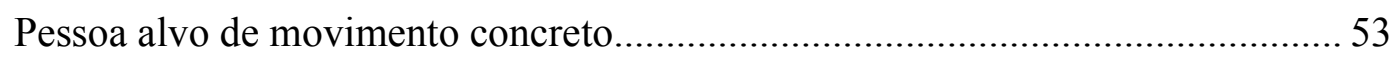

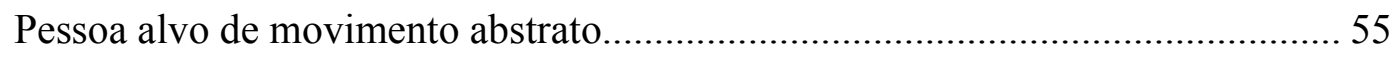

Pessoa alvo de movimento metafórico................................................................56

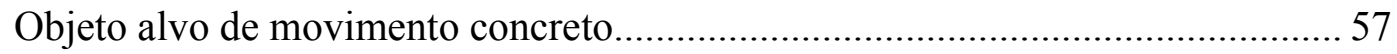

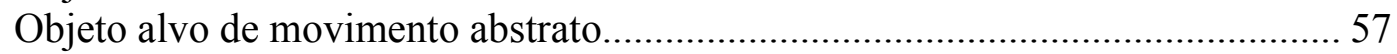

Objeto alvo de movimento metafórico.............................................................5

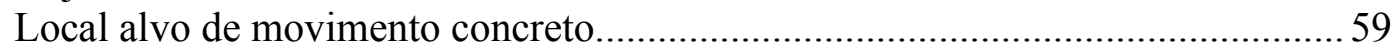

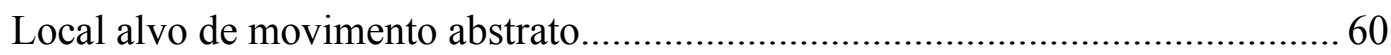




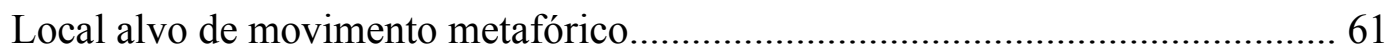

Resumo: mapeamentos na acepção alvo de movimento.......................................62 62

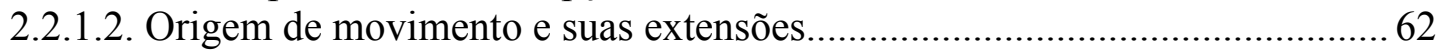

Pessoa origem de movimento concreto..............................................................63

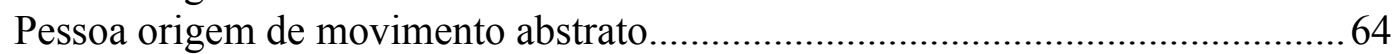

Pessoa, objeto ou local como origem de movimento metafórico...........................64

Objeto origem de movimento concreto..............................................................65

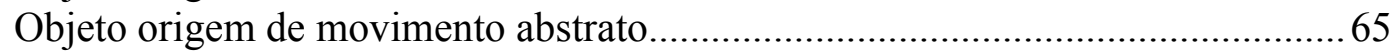

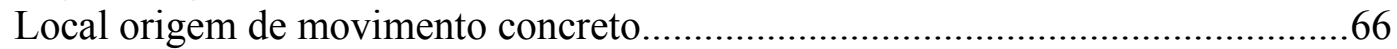

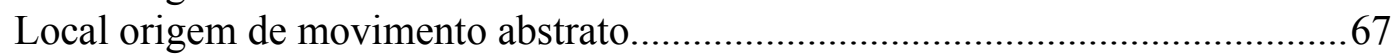

Resumo: mapeamentos na acepção origem de movimento.................................66

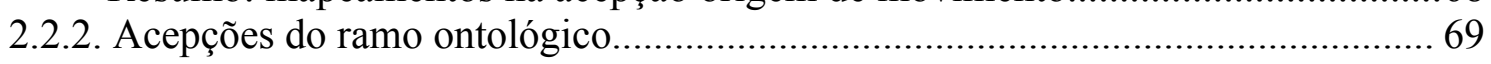

2.2.2.1. Acepções objetivas: local e horário/data.................................................69

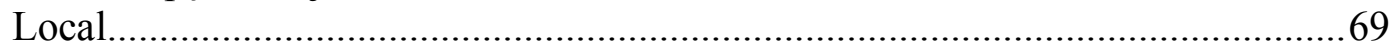

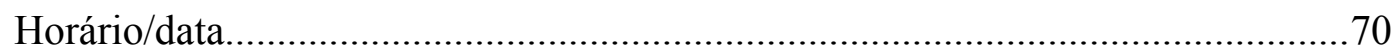

Resumo: mapeamentos nas acepções objetivas............................................... 70

2.2.2.2. Acepções subjetivas: os quatro tipos de sujeito de experiência......................70

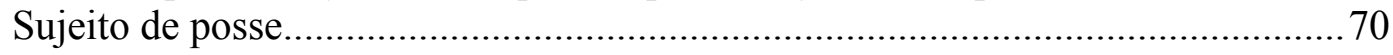

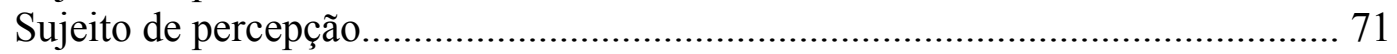

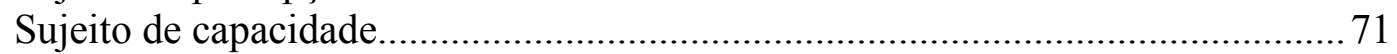

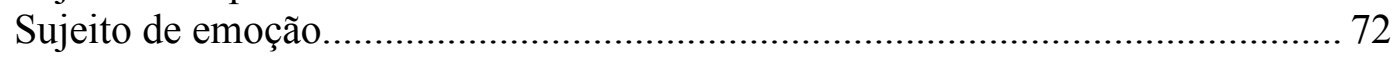

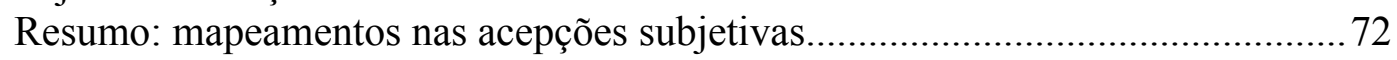

3. As acepções de DE e suas expressões em português......................................................... 73

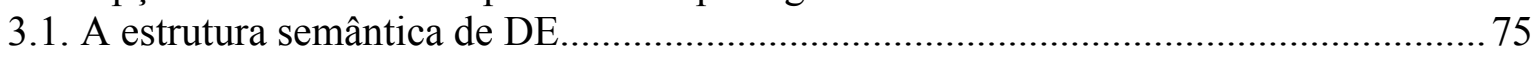

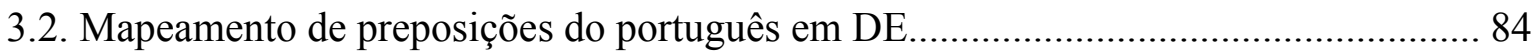

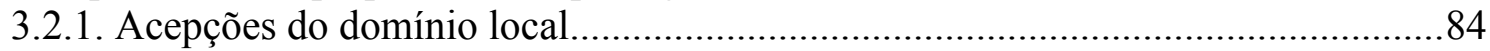

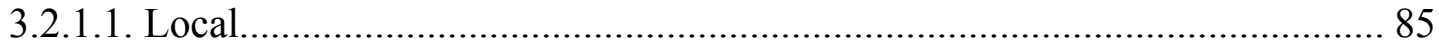

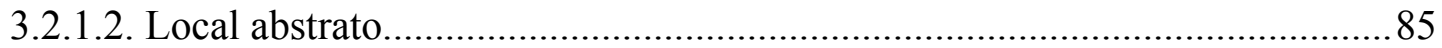

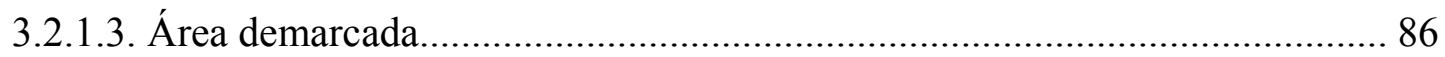

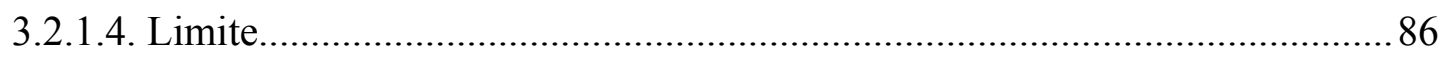

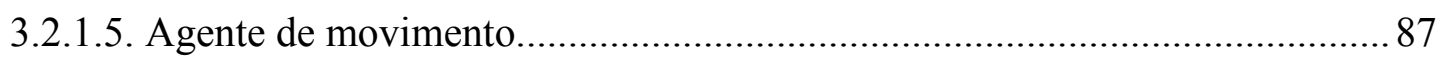

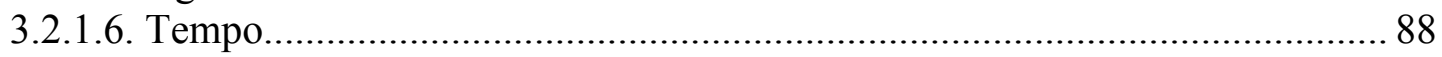

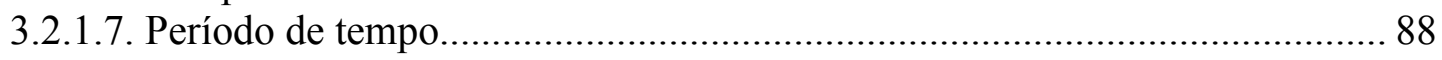

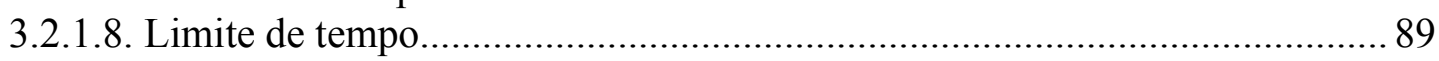

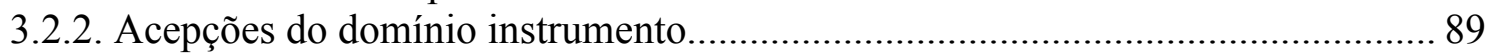

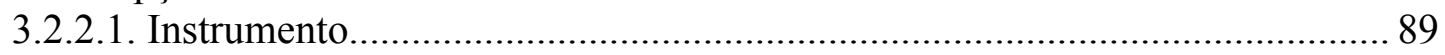

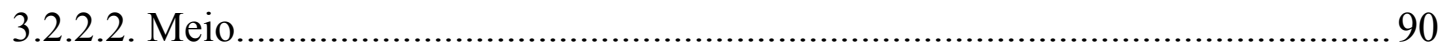

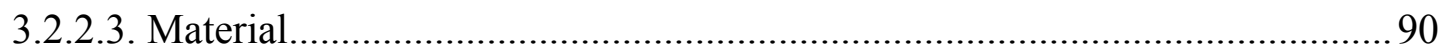

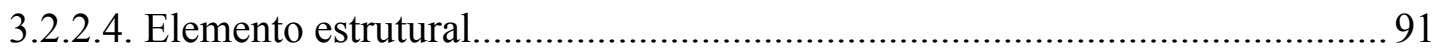

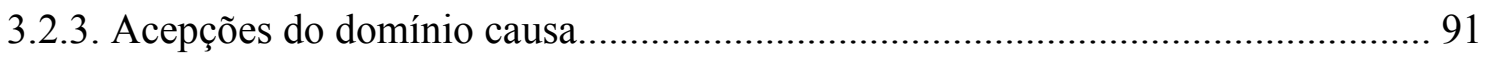

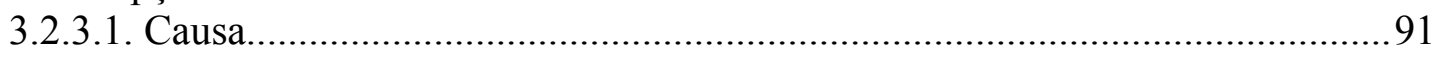

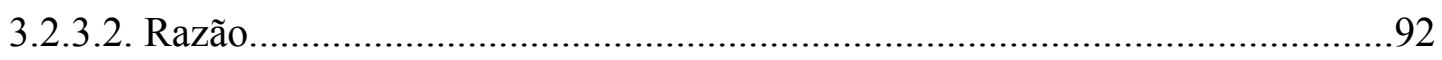

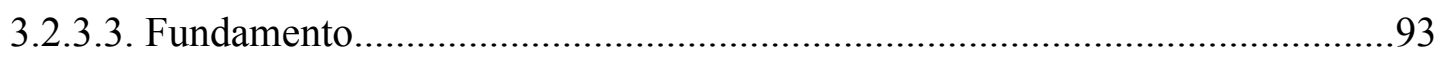

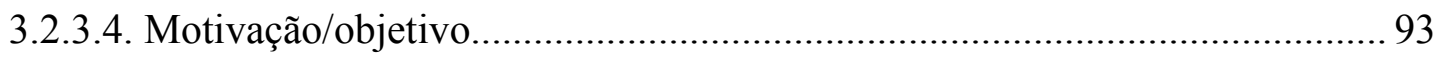

3.2.4. Acepções do domínio situação/aspecto................................................................... 94

3.2.4.1. Situação/aspecto de agente de movimento................................................... 94

3.2.4.2. Situação/aspecto de paciente de movimento....................................................95 
3.2.4.3. Situação/aspecto de movimento ou evento.................................................... 95

3.2.5. Resumo: mapeamentos de preposições em DE................................................... 95

4. As acepções de WO e suas expressões em português........................................................97

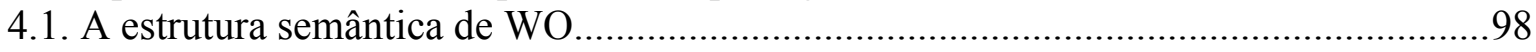

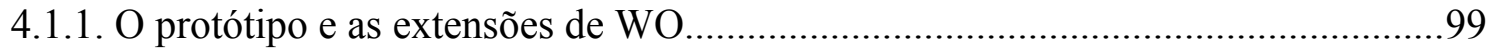

4.1.1.1. A acepção prototípica: objeto direto............................................................ 99

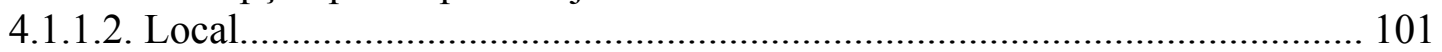

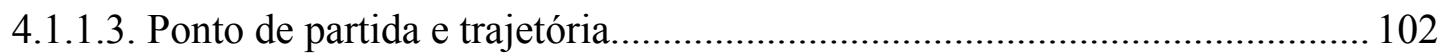

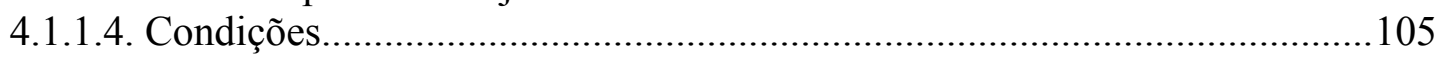

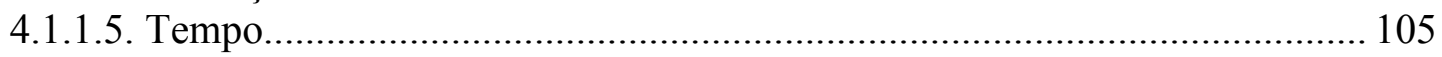

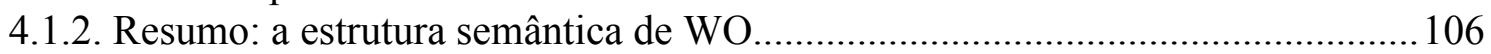

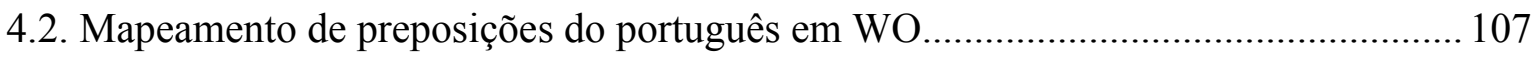

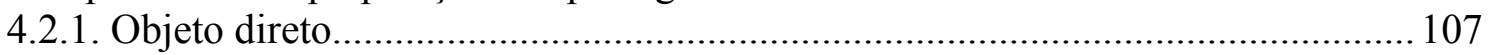

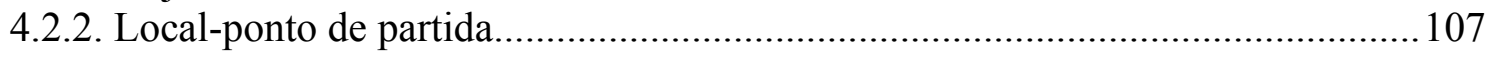

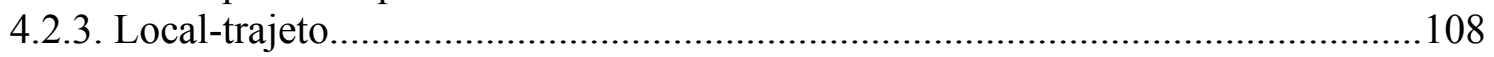

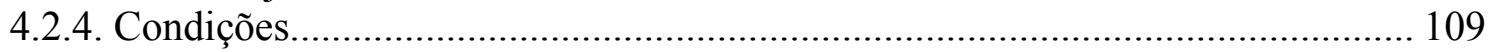

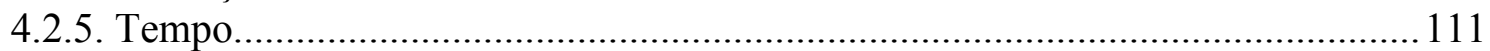

4.2.6. Resumo: mapeamento de marcadores em WO.................................................. 111

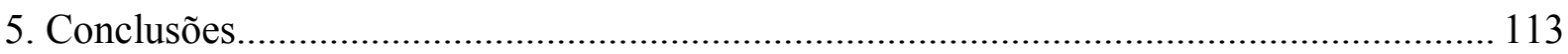

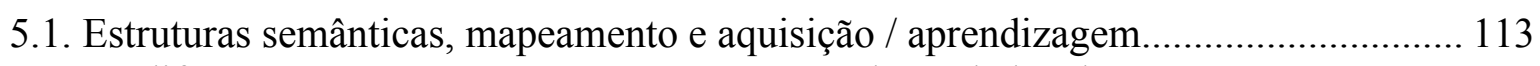

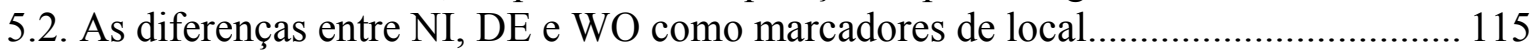

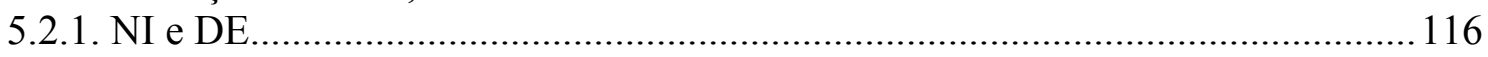

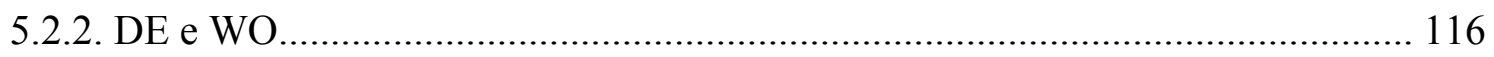

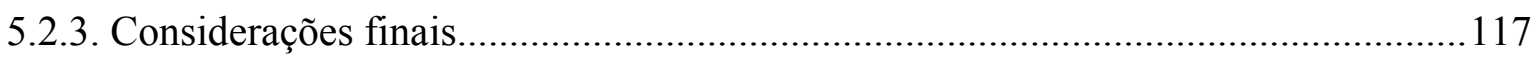

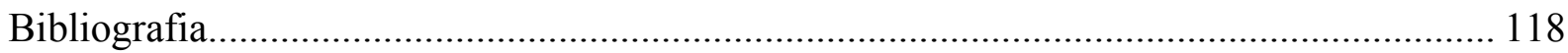




\section{Convenções}

$\mathrm{Na}$ tradução por constituintes das frases de exemplo, adotaremos as seguintes convenções:

1. Posposições, conjunções, verbos auxiliares etc. serão indicados segundo as abreviaturas abaixo. Em maiúsculas estão as abreviações de posposições de caso, e em minúsculas as de auxiliares flexionáveis, verbos auxiliares, etc. A terminologia é baseada em Fukasawa et al. (2001) e Takahashi et al. (2003).

$\begin{array}{ll}\text { ABL } & \text { ablativo } \\ \text { ACS } & \text { acusativo } \\ \text { ADT } & \text { aditiva } \\ \text { ADV } & \text { adversativa } \\ \text { afirm. } & \text { afirmativo } \\ \text { ALT } & \text { alativo } \\ \text { benef. } & \text { benefactivo } \\ \text { caus. } & \text { causativo } \\ \text { CIT } & \text { conteúdo de citação } \\ \text { COM } & \text { comitativo } \\ \text { COND } & \text { condicional } \\ \text { cont. } & \text { contínuo } \\ \text { conv. } & \text { convidativo } \\ \text { CTR } & \text { contraste } \\ \text { desid. } & \text { ênfase } \\ \text { ENF } & \end{array}$




$\begin{array}{ll}\text { GEN } & \text { genitivo } \\ \text { INS } & \text { instrumental } \\ \text { INT } & \text { interrogativo } \\ \text { L-INS } & \text { locativo-instrumental } \\ \text { neg. } & \text { negativo } \\ \text { NOM } & \text { caso nominativo } \\ \text { pasv. } & \text { passivo } \\ \text { perf. } & \text { perfectivo } \\ \text { prog. } & \text { progressivo } \\ \text { sup. } & \text { supositivo } \\ \text { tent. } & \text { tentativo } \\ \text { TER } & \text { terminativo } \\ \text { TOP } & \text { tópico } \\ \text { vol. } & \text { volitivo }\end{array}$

2. A posposição que for objeto de análise do capítulo não será traduzida, devido justamente a seu sentido ser o que está em discussão. Por exemplo, no capítulo sobre NI, não aparecerá a abreviatura DAT (dativo) na tradução por constituintes. O mesmo acontecerá com DE (locativo-instrumental) e WO (acusativo) em seus respectivos capítulos. Exemplos:

\begin{tabular}{|c|c|c|}
\hline \multirow{2}{*}{\multicolumn{3}{|c|}{$\begin{array}{ll}\text { tomodachi ni } & \text { hon wo } \\
\text { amigo NI } & \text { livro ACU } \\
\text { Dou um livro para o amigo. }\end{array}$}} \\
\hline & & \\
\hline $\begin{array}{l}\text { sono kaigi wa } \\
\text { essa reunião TOP }\end{array}$ & amerika & \\
\hline \multicolumn{3}{|c|}{ Essa reunião será realizada nos Estados Un } \\
\hline $\begin{array}{l}\text { hachi-ji ni } \\
\text { oito horas DAT }\end{array}$ & $\begin{array}{l}\text { ie wo } \\
\text { casa WO }\end{array}$ & $\begin{array}{l}\text { deru. } \\
\text { sair }\end{array}$ \\
\hline
\end{tabular}




\section{Introdução: motivação, objetivo e fundamentação teórica}

\subsection{Motivação}

Um dos desafios que se impõem aos aprendizes não só da língua japonesa, mas provavelmente também de qualquer outro idioma como língua estrangeira, é o domínio dos nexos gramaticais, tais como preposições ou posposições, morfemas de caso e conjunções. Para explicitar as relações entre determinados elementos (por exemplo, entre determinadas ações e suas circunstâncias), as diferentes línguas usam nexos com sentidos prototípicos distintos: as diferenças entre os usos de IN, AT e ON do inglês e NI, WO e DE do japonês são exemplos clássicos das questões enfrentadas no âmbito dos nexos pelos falantes de português na aprendizagem dessas línguas.

Some-se a isso a questão da polissemia dos nexos. Para efeito de ilustração, reproduziremos aqui a entrada do Daijirin (MATSUMURA, 1999) para a posposição de caso $\mathrm{NI}^{1}$. (Os exemplos de uso exclusivo do japonês clássico foram suprimidos.)

\section{NI}

1) posposição de caso

Vocábulo usado desde a antigüidade, seu uso essencial é o de indicar a localização ou os limites temporais ou espaciais de um movimento, uma ação ou uma existência.

1. Indica tempo.

goji NI okiru

cinco horas NI acordo

Acordo às cinco horas.

shigoto no aima NI hon wo yomu

trabalho-GEN intervalo NI livro-ACS leio

Leio livros nos intervalos do trabalho

2. Indica local / limites.
apâto NI sumu
apartamento NI mora
Moro em um apartamento
sora NIhoshiga matataku

\footnotetext{
1 Todas as citações deste trabalho foram traduzidas por mim, salvo onde houver indicação.
} 
céu NI estrela-NOM cintila

Estrelas cintilam no céu

3. Indica alvo / objeto.

dokusho NI necchûsuru

leitura NI empenha-se

Empenho-me na leitura

sakanatsuri NI iku

pescaria NI vou

Vou à pescaria

kimi NI misete yarou $k a$

você NI mostrar-benef.-conv. INT

Quer que mostre para você?

4. Expressa ponto de chegada, direção etc. aonde se aplica um movimento.

ie NI tadoritsuku

casa NI chego

Chego em casa.

kuruma NI noru

carro NI embarco

Embarco no carro.

kitoku NI ochiiru

beira da morte NI cai

Cai à beira da morte.

5. Expressa causa, motivação etc. de movimento / ação.

yamanobori NI muchû ni naru

alpinismo NI fanatismo-DAT tornar-se

Tornar-se fanático por alpinismo.

maeiwai NI sake wo nomu

comemoração prévia NIsaquê-ACS beber

Beber saquê como comemoração prévia.

osoroshisa NI furueru

terror NI tremer

Tremer de terror

yabuka NI kurushimu

mosquito NI sofrer

Sofrer com os mosquitos.

6. Expressa padrão de comparação / proporção.

ikkagetsu NI futsukano yasumi

um mês NI dois dias-GEN descanso

Descanso de dois dias por mês

oya NI ninu ko

pais NI parece-neg. criança

Criança que não se parece com os pais

ko NI masaru takara wa nai

filho NIsupera tesouro-TOP não há 
Tesouro que supere um filho, não há.

7. Expressa origem de movimento / ação.

$\begin{array}{ll}\text { hito NI } & \text { butareru } \\ \text { pessoa NI } & \text { esmurrar-pasv. } \\ \text { Ser esmurrado por uma pessoa. }\end{array}$

$\begin{array}{lll}\text { nusutto NI } & \text { kane wo } & \text { torareru } \\ \text { ladrão NI } & \text { dinheiro-ACS } & \text { tira-pasv. } \\ \text { Ter o dinheiro tirado pelo ladrão } & \end{array}$

8. Expressa o sentido de qualificação.

gohôbi NI sen'en wo morau

prêmio NI mil ienes-ACS ganha

Ganha mil ienes como prêmio.

9. Expressa resultado de mudança.

$\begin{array}{ll}\text { gakusha NI } & \text { naru } \\ \text { acadêmico NI } & \text { torna-se } \\ \text { Torna-se um acadêmico. }\end{array}$

hoshi NI naritai

estrela NI torna-se-desid.

Quero me tornar em uma estrela.

10. Expressa modo de realização de movimento / característica de estado de coisas.

\author{
saŷि NI yureru \\ direita-e-esquerda NI oscila \\ Oscilar para a direita e para a esquerda. \\ pikapika NI hikaru \\ cintilante NI brilha \\ Brilha cintilantemente. (Cintila.)
}

O restante do material descritivo da língua japonesa (gramáticas, dicionários, livros didáticos) pesquisado para este trabalho traz outras descrições dessa mesma ordem de grandeza. Ocorre ainda que dentro desse material também encontramos diversos recortes, ou seja, diversas formas de organizar os sentidos de NI, inconsistentes, por vezes, entre si.

Diante disso, no curso de mestrado, buscamos em uma primeira fase o que seria o sentido essencial, comum a todas as manifestações da posposição NI. Entretanto, o 
estabelecimento de um traço semântico (por exemplo, o de indicar um ponto no tempo ou no espaço, ou uma direção) comum a toda e qualquer ocorrência desse morfema mostrou-se insuficiente para definir seu significado: de fato, cabe outrossim organizar seus diversos sentidos, elucidando quais seriam as relações existentes entre eles.

No universo das pesquisas sobre a língua japonesa, essa tarefa se encontra em estágio bastante avançado. As realizações nessa área encontram seu ponto culminante no trabalho de Moriyama (2005), que apresenta uma análise detalhada e exaustiva das estruturas semânticas das posposições de caso do japonês, inclusive com aplicações dessa teoria a estudos sobre sua aquisição por falantes nativos de coreano e chinês.

No entanto, até onde temos conhecimento, não há trabalhos acadêmicos que façam comparações dos diferentes sentidos de posposições do japonês, organizados de forma clara e consistente, com expressões equivalentes em língua portuguesa. Antes do conhecimento sobre as estruturas semânticas das posposições (bem como de outras expressões lingüísticas), tudo o que se poderia ter eram recortes limitados dos possíveis sentidos desses elementos, ficando sempre a impressão de que seria impossível defini-los. Contudo, com base nas últimas pesquisas nessa área, cremos que já se possa partir com razoável segurança para um estudo comparativo, que estabeleça semelhanças e diferenças entre os nexos do japonês e do português. Esses estudos podem chegar a nos mostrar "os limites do traduzível" e contribuir para o aumento da eficácia do ensino, auxiliando-nos a superar os obstáculos oferecidos pelas estruturas estabelecidas pela língua nativa do aprendiz.

\subsection{Objetivo}

O objetivo do presente trabalho é discutir as diferentes acepções das posposições de caso NI, WO e DE, a partir de suas estruturas semânticas, com relação a preposições e 
construções que transmitam sentidos equivalentes em português, destacando semelhanças e diferenças.

\subsection{Fundamentação teórica}

\subsubsection{Semântica cognitiva - aspectos gerais}

A semântica cognitiva é um ramo da semântica que estuda padrões conceituais humanos e a expressão desses padrões na linguagem.

\subsubsection{Esquemas de imagem e metáforas conceituais}

Lakoff e Johnson (1999, p. 497) apontam para dois resultados básicos vindos das pesquisas em semântica cognitiva. O primeiro é que nossas capacidades de percepção e de movimento são uma fonte importante dos conceitos humanos. Por exemplo, muitos conceitos espaciais emergem de nossa experiência corporal e da interação com o ambiente. O segundo resultado é que conceitos também podem surgir e ser estruturados por "aspectos imaginativos da mente", como metáfora e metonímia.

Por exemplo, afirma-se que o conceito de tempo é compreendido em termos da noção mais básica de espaço. Mais especificamente, o conceito de tempo surge como uma extensão metafórica de conceitos de relações espaciais.

De acordo com essa visão da cognição, alguns conceitos humanos são mais básicos que outros. Os conceitos mais básicos, dos quais os esquemas de imagem constituem um tipo, surgem através da experiência corporal. Um desses esquemas de imagem é o chamado esquema CONTINENTE $^{2} 3$ (cf. LAKOFF, 1987, p. 272), que é a conceitualização de uma região espacial limitada - o corpo humano, por exemplo. Outro esquema de imagem é o PARTE-TODO,

2 Seguiremos a notação adotada por Lakoff (1997), escrevendo os nomes de esquemas de imagens, metáforas conceituais e seus componentes em MAIÚSCULAS PEQUENAS.

3 Neste ponto do texto, em que não há um contexto mais abrangente, uma tradução mais clara para o termo container usado por Lakoff talvez fosse "recipiente". Entretanto, Castilho (2004) fala em "eixo continenteconteúdo", e assim optamos por privilegiar a consistência da terminologia. 
pelo qual conceitualizamos objetos complexos como máquinas e inclusive objetos sem limites ou partes inerentemente definidos, como as montanhas, como sendo compostos por partes. Um dos esquemas mais importantes para este trabalho é o de DINÂMICA DE FORÇAS, que atribui aos objetos percebidos papéis de agente, paciente, instrumento etc.

Lakoff (1987, cap. 17) descreve esquemas de imagem com respeito a três propriedades: a experiência corporal que origina o esquema, os elementos estruturais especificados pelo esquema e a lógica básica que ele produz. Tomando o esquema conTINENTE, referido acima, como exemplo, argumenta-se que sua base experiencial é nosso conceito de corpo humano como um recipiente, cujos elementos estruturais são INTERIOR, LIMITE e EXTERIOR. Sua lógica básica diz, entre outras coisas, que um ente que está dentro de um continente não está fora dele - em termos lógicos, "P ou não $P^{"}$ (LAKOFF, 1987, p. 272).

Dos esquemas de imagem surgem conceitos mais abstratos. Um meio de dar extensões a um esquema de imagem é a metáfora. Metáforas, segundo Lakoff (1993, p. 203) são "mapeamentos gerais entre domínios conceituais". Por exemplo, Lakoff e Johnson (1999, cap. 10) argumentam que o tempo é conceitualizado em termos de conceitos espaciais, e que a relação entre os dois domínios conceituais, espaço e tempo, é metafórica. Essa metáfora é entendida como um mapeamento entre um domínio espacial e um temporal.

Em mapeamentos metafóricos, o domínio mais básico, isto é, o domínio baseado diretamente na experiência, é chamado de domínio-origem. O domínio mais abstrato, que conceitualizamos em função do domínio-origem, é chamado de domínio-alvo. Na relação entre um domínio espacial e um temporal, o domínio espacial é o domínio-origem e o domínio temporal é o domínio-alvo. Em geral, a relação entre os domínios origem e alvo é limitada pelo princípio da invariância: 
Mapeamentos metafóricos preservam a topologia cognitiva (isto é, a estrutura do esquema de imagem) do domínio-origem, de um modo consistente com a estrutura inerente do domínio-alvo. (LAKOFF, 1993, p. 215)

O princípio da invariância tem dois importantes corolários concernentes à relação entre os domínios origem e alvo. Primeiro, existe uma correspondência entre elementos estruturais. Se um mapeamento metafórico tem o esquema de imagem de CONTINENTE como domínio-origem, com seus elementos estruturais INTERIOR, LIMITE e EXTERIOR, o domínio-alvo conterá os mesmos elementos estruturais. Por exemplo, Lakoff (1993, p. 212 em diante) discute um mapeamento metafórico baseado no esquema CONTINENTE segundo o qual CATEGORIAS CLÁSSICAS SÃo CONTINENTES ${ }^{4}$. Se categorias clássicas são entendidas como continentes, pelo princípio da invariância elas têm um INTERIOR, um EXTERIOR e Um LIMITE entre O INTERIOR O O EXTERIOR.

Segundo, os princípios lógicos básicos do domínio-origem se mantêm também no domínio-alvo. Na metáfora CATEGORIAS CLÁSSICAS SÃo CONTINENTES, reconhecemos a oposição "P ou não $P^{\prime \prime}$ ou um ente é um membro da categoria, ou seja, está dentro da categoria, ou não é um membro, ou seja, está fora da categoria.

Os estudiosos da semântica cognitiva têm o cuidado de notar que a metáfora é um fenômeno cognitivo, e não lingüístico. Desse modo, expressões lingüísticas não são metáforas em si mesmas. Antes, expressam metáforas. Mais ainda, se por um lado metáforas conceituais são amplos mapeamentos entre vários domínios conceituais, por outro lado expressões lingüísticas freqüentemente manifestam submapeamentos entre domínios; por exemplo, mapeamentos de um elemento estrutural no domínio-origem para um elemento correspondente no domínio-alvo. Quando dizemos que um ente está em uma categoria, destacamos, por meio da preposição em, o elemento INTERIOR no domínio-alvo - em analogia

\footnotetext{
4 Seguiremos a notação adotada por Lakoff (1997), escrevendo as metáforas conceituais na forma DOMÍNIO-ALVO
} É DOMÍNIO-ORIGEM. 
com o INTERIOR do domínio-origem. Em contraste, os outros dois elementos estruturais desse mapeamento, LIMITE e EXTERIOR, não são aludidos por essa preposição.

\subsubsection{Categorização}

A estruturação das línguas naturais passa obrigatoriamente pela capacidade humana de fazer categorizações, isto é, de organizar objetos, fatos e atos, conforme nós os percebemos, sob rótulos - as palavras.

Lakoff (1987) observa que a forma aristotélica de categorização e a teoria dos conjuntos, que classificam elementos exclusivamente de acordo com propriedades em comum, poucas vezes correspondem à categorização processada na atividade da criação lingüística. Para as categorias representadas nas palavras, é preciso considerar outros critérios de pertencimento. Destacaremos o critério das semelhanças de família (family resemblances) e as relações de encadeamento.

\section{Semelhanças de família}

O conceito de semelhanças de família foi idealizado por Wittgenstein (1953, apud LAKOFF, 1987; WIERZBICKA, 1996; HEBECHE, 2005, entre outros), e diz, basicamente, que termos genéricos não possuem condições necessárias e suficientes que os definam. Em vez disso, os itens que colocamos sob determinado rótulo são relacionados uns aos outros por certas características. Como ilustração, vejamos o conceito de jogo do próprio Wittgenstein. Ele coloca que, se observarmos a totalidade do que chamamos de jogos no mundo, concluiremos que não há traços universais que formem condições necessárias e suficientes para defini-los. Jogos de cartas têm semelhanças com jogos de bola, mas também muitas diferenças. O mesmo se verifica se compararmos esses jogos com os jogos de tabuleiro e jogos infantis. O que encontramos é uma malha de características que entrelaça os conceitos 
entre si. Por exemplo, se por um lado tanto jogos de tabuleiro como jogos de cartas podem envolver o uso de cartas, por outro lado os jogos de cartas não exigem o uso de tabuleiros. Ou, enquanto jogos de bola e jogos infantis são divertidos, o xadrez não o é necessariamente. Assim, o conceito de jogo seria estruturado por uma rede de semelhanças de família.

\section{Uma ressalva para o conceito de categorias como redes indefinidas de semelhanças de família}

Para Wittgenstein, o fato de o conceito de jogo consistir em uma rede de semelhanças de família impede o usuário comum da língua de defini-lo, mas não de compreendê-lo. Segundo esse raciocínio, cada vez que empregamos o conceito de jogo, fazemos isso com uma finalidade específica, estabelecendo limites que fecham o conceito momentaneamente. Ao falar de um jogo, digamos de um jogo de cartas, fechamos o conceito para esse propósito em especial. Da mesma forma, não é necessário definir a essência de cada constituinte de uma sentença para compreendê-la. Por exemplo, para compreender o enunciado "o solo está inteiramente coberto de plantas", não é necessário definir exatamente "solo", "planta" ou "inteiramente coberto" (WITTGENSTEIN, 1953 apud HEBECHE, 2005).

Consideramos, no entanto, que a complexidade para que Wittgenstein chama a atenção com a noção das semelhanças de família não deve afastar o lingüista de buscar delimitações para as categorias representadas pelas palavras. Wierzbicka (1996, cap.4) alerta para esse fato, e traz, inclusive, um conjunto de condições necessárias e suficientes para definir jogo:

$$
\text { jogos }
$$

a) muitos tipos de coisas que pessoas fazem

b) por algum tempo

c) "por prazer" (isto é, porque querem sentir algo bom)

d) quando pessoas fazem essas coisas, pode-se dizer sobre essas pessoas que:

e) querem que certas coisas aconteçam [têm objetivos]

f) se não estivessem fazendo essas coisas, não quereriam que essas 
coisas acontecessem [fora do jogo esses objetivos não têm valor]

g) não sabem o que acontecerá [os resultados de um jogo são imprevisíveis]

h) sabem o que podem fazer

i) sabem o que não podem fazer [agem sob determinadas regras]

(WIERZBICKA 1996, p.159)

Nessa análise, Wierzbicka chama a atenção para as propriedades dos jogos relacionadas aos próprios jogadores, o que Lakoff (1995) chamaria de propriedades interacionais, e que Wittgenstein ignora ao descrever o conceito de jogo. Wierzbicka (idem, cap. 4) ainda traz outras definições para conceitos igualmente considerados vagos por Lakoff e outros autores, como mãe, mentira, pássaro etc.

Diante do exposto, parece-nos que a noção de semelhanças de família para explicar como o ser humano compreende o mundo no nível consciente é bastante útil, mas não nos esqueceremos de que características invariáveis podem e devem ser buscadas para se completar a definição de uma categoria. Como coloca Wierzbicka (1996, p. 160), "limites existem, $[\ldots]$ e falantes nativos subconscientemente conhecem-nos e os respeitam".

Essas características invariáveis, abstratas, que unem todos os elementos dentro de uma categoria e são aplicadas inconscientemente pelo usuário da língua, formam o que Moriyama (2005), entre outros autores, chama de super-esquema.

\section{Encadeamento de sentidos}

Tomemos o conjunto das acepções da palavra folha: a acepção de órgão de planta motiva a de pedaço de papel, pelas propriedades compartilhadas: formato laminar, fragilidade e flexibilidade. Por sua vez, a acepção pedaço de papel motiva a de periódico, dado que jornais e afins são escritos em folhas de papel. Não há relação direta de sentido entre o 
periódico e o órgão da planta. O usuário da língua reconhecerá a centralidade da primeira acepção, ou seja, de que órgão da planta seria o sentido prototípico de folha. Se chamarmos essas acepções de A, B e C respectivamente, podemos representar as relações que as ligam como segue:

$$
\mathrm{A} \rightarrow \mathrm{B} \rightarrow \mathrm{C}
$$

Na cadeia de sentidos ilustrada acima, B é motivado por A e C é motivado por B; mas C não é, pelo menos aparentemente, relacionado a A. C é um elemento periférico da categoria, e A é um elemento central ou prototípico. As acepções de folha órgão de planta, pedaço de papel e periódico estão ligadas dessa forma, ou seja, estão encadeadas.

\section{O que é, então, uma estrutura semântica}

A estrutura semântica de um elemento lingüístico é a rede que interliga suas diversas acepções. Essa rede tem como característica fundamental um desenho radial, em cujo centro está o sentido prototípico do lexema ou morfema, associado a um esquema de imagem cognitivo, e a partir do qual se motivam acepções mais abstratas. Uma acepção pode motivar outra, e assim sucessivamente até que seja difícil enxergar diretamente a relação das acepções periféricas com o protótipo. No entanto, é possível abstrair um conjunto de características comuns a todas as acepções: esse é o super-esquema, que delimita o contorno da categoria.

Em termos práticos, para o estabelecimento da estrutura semântica de um determinado elemento lingüístico, deve-se responder às seguintes questões:

Qual é o significado prototípico do elemento, ou seja, o significado mais concreto, motivado por nossa experiência física?

Quais são as acepções motivadas pelo protótipo, e como estão encadeadas? 
Qual é o super-esquema que une todas as acepções do elemento?

\section{Semântica cognitiva e as posposições de caso ${ }^{5}$}

\section{O reconhecimento humano do mundo externo e a expressão dos casos}

O pensamento da semântica cognitiva acerca dos casos está resumido em Langacker (1991a, 1991b). Para esse autor, os seres humanos, na condição de sujeitos da cognição, vemos o mundo externo como uma rede estruturada por elementos inter-relacionados (interactive network), como na Figura 1a. Ocorre que, em nossas atividades mais comuns, voltamos nosso interesse para uma cadeia de ações (Figura 1b), recortamos um escopo, tomamo-lo como objeto de uma predicação (Figura 1c) e formamos, a partir dessa base, um perfil (profile, Figura 1c) que relaciona os entes (participantes) entre si.

(a) REDE DE INTERAÇÕES

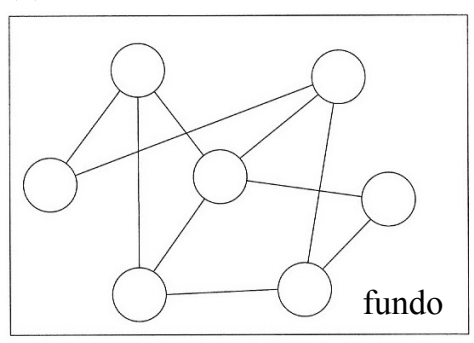

(c) ESCOPO DA PREDICAÇÃO

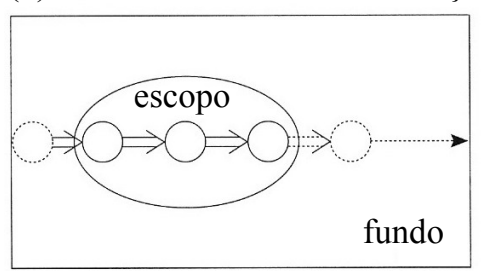

(b) CADEIA DE AÇÕES

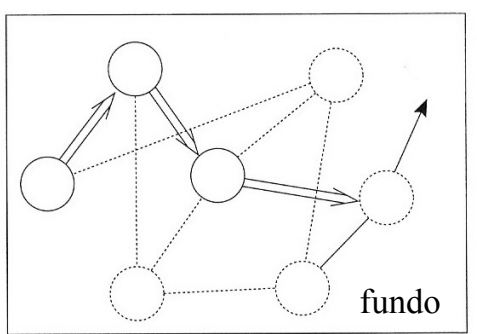

(d) PERFILAMENTO

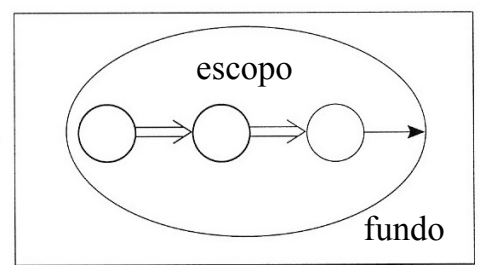

Figura 1. Processo de cognição do mundo externo (LANGACKER, 1991b, p. 215)

Ao se dar forma a esse processo na linguagem, normalmente o participante do nível mais alto da cadeia de ações é reconhecido com o maior destaque (Trajector), e verbalizado como sujeito (S). Já o participante do nível mais baixo da cadeia de ações é o outro elemento mais destacado além do Trajector (Landmark), e toma forma na linguagem como objeto (O).

\footnotetext{
5 Este item é uma adaptação do texto de Moriyama (2005, pp. 2 et seq.), em cotejo com Langacker (1991a,
} 1991b). 
Esse raciocínio é ilustrado na Figura 2.

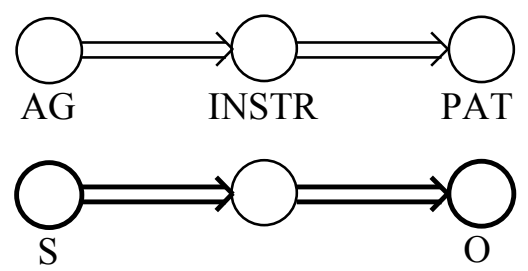

Figura 2. Representação de uma cadeia de ações. Embaixo, efeito do destaque dos participantes, em que o sujeito coincide com o agente, o objeto, com o paciente, e o instrumento não é determinado.

Ainda, como papéis prototípicos dos participantes nas cadeias de ações, temos agente (AG), instrumento (INSTR), tema (TH) (que pode ser paciente (PAT) ou movente (MVR)), experiente (EXPER), etc. Os papéis podem ser organizados em termos de domínios: o domínio-origem da ação e o domínio-alvo da ação, constituindo quatro tipos: participante ativo do domínio-origem, participante passivo do domínio-origem, participante ativo do domínio-alvo e participante passivo do domínio-alvo (Figura 3). Na expressão lingüística, os três primeiros papéis seriam representados, respectivamente, pelos casos nominativo, instrumental e dativo (LANGACKER, 1991a, p. 327). O último também é representado pelo nominativo, mas como uma extensão do sentido prototípico de agente.

Domínio-Origem Domínio-Alvo

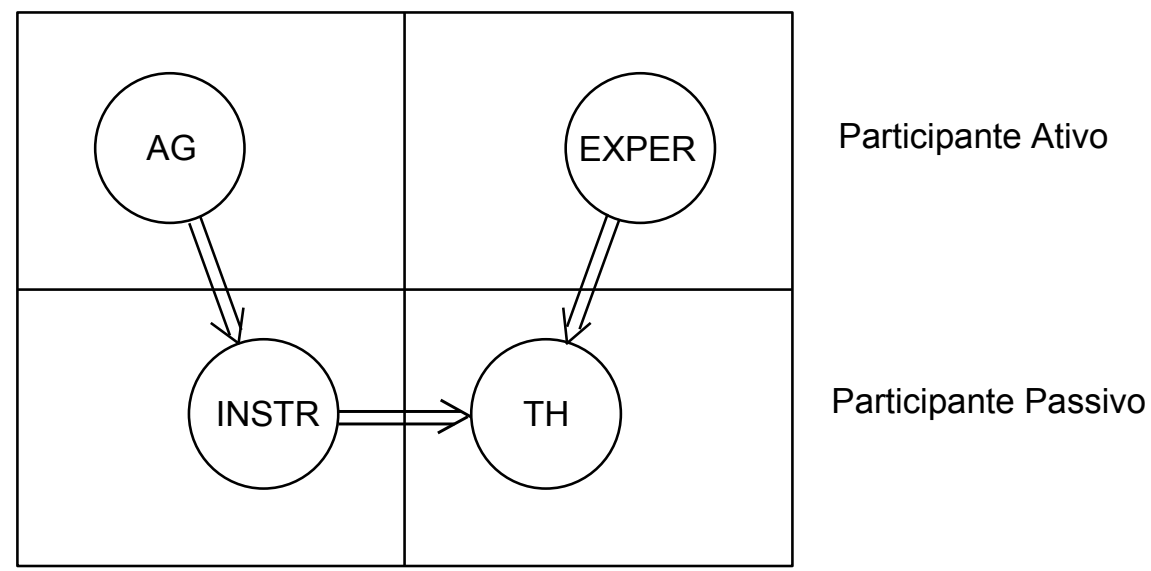

Figura 3. Cadeia de ações transitiva e os papéis dos participantes (LANGACKER, 1991b, p. 217) 


\section{Figura e fundo}

Conforme exposto acima, o mundo que nos cerca pode ser visto como um sem-número de entes e relações, mas, como sujeitos da cognição, fazemos recortes (definimos escopos) para os quais voltamos a atenção. Ainda, dentro desse escopo, como em um cenário, separamos os entes que ficarão em primeiro plano, isto é, as figuras, dos outros, que comporão o fundo. Desse modo, os casos devem expressar a condição dos participantes como figuras ou como partes do fundo.

\section{Os conceitos de protótipo e encadeamento aplicados à sintaxe: transitividade, sujeito e objeto}

Langacker (1991a, 1991b) coloca o sujeito e o objeto em termos de protótipos e esquemas de imagem para relacioná-los com a transitividade do verbo.

No processo de perfilação de participantes dentro de um escopo, na rede de relações que forma o mundo à nossa volta (ver item "O reconhecimento humano do mundo externo e a expressão dos casos"), o sujeito da cognição concentra sua atenção em uma cadeia de ações. Essa cadeia envolve uma dinâmica de forças. Se na cadeia destacada aparecer apenas um participante (foco na última conseqüência de uma cadeia), temos uma expressão intransitiva; se aparecerem dois ou mais participantes, tem lugar uma expressão transitiva.

O sujeito (caso nominativo) e o objeto (caso acusativo) prototípicos são os dois participantes do esquema de imagem DINÂMICA DE FORÇAS assim estruturado. A transitividade prototípica é a relação de transmissão direta de energia de um agente para um paciente. $\mathrm{O}$ caso nominativo prototípico é aquele que expressa o agente em uma relação transitiva e o caso acusativo prototípico é o que expressa o paciente em uma relação transitiva (ver Figura 4 (a)). Os exemplos de frases 1(a) e (b) a seguir mostram casos prototípicos de sujeito e objeto. Nas frases (c) e (d) o objeto é um movente (MVR), em um exemplo próximo do protótipo. 
1. a) João quebrou a janela.

b) Maria derreteu o gelo.

c) João empurrou o carro.

d) Maria abriu a janela.

Naturalmente, entretanto, nem todas as relações transitivas expressas na linguagem correspondem exatamente ao protótipo. Nas frases do exemplo 2 abaixo, em que se trata de sujeitos de experiência, e em 3, nos quais se expressam relações puramente abstratas, a imagem da dinâmica de forças vai dando lugar à noção mais abstrata de contato mental, e assim essas relações devem ser consideradas como extensões do protótipo.

2. a) João viu um homem.

b) Maria ouviu as notícias.

3. a) Hilda lembra Márcia.

b) A linha A corta a linha B.

Dessa forma, podemos ver a relação transitiva como uma categoria construída por encadeamento, com as relações representadas por sentenças como "quebrar o vidro" no centro (elemento central ou prototípico), e outras relações, daquelas de experiência até as puramente abstratas, em pontos menos ou mais distantes do centro; todas, no entanto, prontamente reconhecidas pelo usuário da língua como relações de transitividade para fins de expressão.

Conforme a relação expressa pela linguagem se afasta do protótipo, concreto, para os elementos periféricos, mais abstratos, evidencia-se a projeção das características do protótipo em um esquema. Como resultado, a definição que se aplica para todas as relações pertencentes à categoria das relações transitivas se abstrai, na seguinte fórmula: Em uma relação assimétrica entre dois participantes, o caso que expressa o participante mais destacado (Trajector) é o nominativo, e o caso que expressa o segundo participante mais 
destacado (Landmark) é o acusativo. Em resumo, as relações entre os protótipos e os esquemas aqui referidas podem ser organizadas como abaixo.

\section{Transitividade}

- Prototípica: transmissão de energia de um agente a um paciente

- Esquemática: relação assimétrica entre dois participantes

\section{Sujeito}

- Prototípico: o agente como nó inicial da cadeia de ações

- Esquemático: o participante com o maior destaque na relação assimétrica (Trajector).

6. $\underline{\text { Objeto }}$

- Prototípico: o paciente como nó final da cadeia de ações.

- Esquemático: o participante com segundo maior destaque na relação assimétrica (LM).

A descrição acima se refere à forma não-marcada. Em formas marcadas, o sujeito da cognição pode interpretar, por exemplo, o objeto da ação com maior destaque que o agente. Consideremos as frases em (7), representadas graficamente na Figura 4 (no final deste item). As setas grossas representam as dinâmicas de forças, ou seja, movimentos, perfilados pelo sujeito da cognição; as setas finas são os movimentos não perfilados; as setas tracejadas representam forças fora do escopo recortado.

7. a) Ele abriu a porta.

b) A porta se abriu facilmente.

c) A porta se abriu de repente.

d) A porta foi aberta.

A frase (a) representa a forma não-marcada de relação transitiva, com o agente 
concidindo com o trajector, ou seja, verbalizado como sujeito, e o paciente, com o landmark, como objeto direto. Nas expressões de forma intransitiva (b), (c) e (d), o perfil é deslocado e limitado: o agente não é especificado e o paciente é verbalizado como sujeito. Em (b), o complemento facilmente sugere a influência de um agente dentro do escopo, ainda que implícito. Em (c), o agente é completamente apagado. Na forma passiva (d), apesar de o agente não ser especificado, pode-se reconhecer novamente a cadeia de ações completa, ainda com o paciente verbalizado como sujeito. A cadeia de ações é a mesma para as quatro frases, ou seja, o elemento porta é paciente da ação. Porém, os exemplos de (b) a (d) trazem o paciente como o elemento mais destacado do cenário, através de sua focalização como sujeito, e o agente desfocado. Aplica-se, pois, o esquema segundo o qual o sujeito (caso nominativo) é o participante mais destacado (TR) em uma relação assimétrica, com as frases em formas marcadas ((b) a (d)) representando extensões do protótipo expresso pela forma não marcada em (a).

(a)

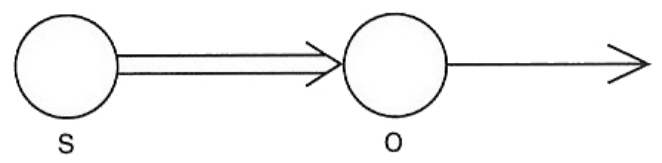

(C)

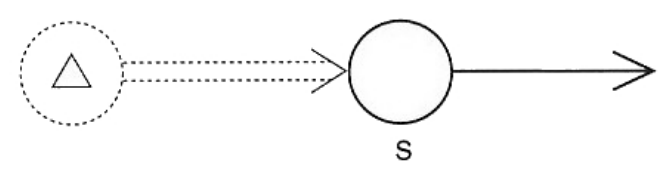

(b)

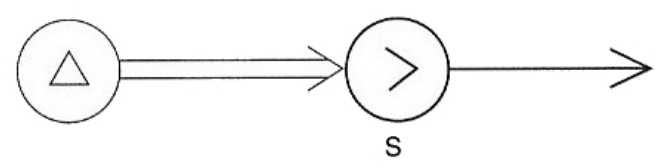

(d)

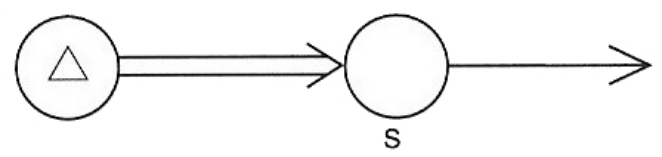

Figura 4. Expressão gráfica das percepções nos exemplos 7a a 7d (LANGACKER, 1991a, p. 335). Setas duplas indicam "transmissão de energia"; setas simples indicam "movimento resultante"; o sinal (>) significa "facilitação"; o triângulo indica "não especificado".

\subsection{Considerações sobre o objeto de análise e referencial teórico específico}

Escolhemos como objeto de análise as posposições NI, WO e DE porque, entre as várias acepções a que estão associados cada um desses três morfemas, aparece em comum a 
função de marcador de lugar. Nessa acepção, basicamente, NI se associa a uma localização, onde um ente está estacionado; WO a uma trajetória, por onde se faz um deslocamento; e DE, a um ambiente, onde se realiza uma atividade.

$\begin{array}{llll}\text { 8. } & \text { Tôkyô } & \text { NI } & \text { sunde iru. } \\ \text { Tóquio } & \text { NI } & \text { moro } \\ & \text { Moro em Tóquio. } & \\ \text { 9. } & \text { Tôkyô } & \text { WO } & \text { aruku. } \\ \text { Tóquio } & \text { WO } & \text { ando } \\ \text { Ando por Tóquio. } & \\ \text { 10. Tôkyô } & \text { DE } & \text { hataraku. } \\ \text { Tóquio } & \text { DE } & \text { trabalho } \\ \text { Trabalho em Tóquio. }\end{array}$

Um primeiro exame nos exemplos acima já mostra que a distinção expressa por NI e DE (exemplos 8 e 10) não se reflete no português. Já a posposição WO na acepção de marcador de lugar encontra obstáculos para a assimilação por aprendizes não-nativos devido a seu sentido prototípico ser o de objeto direto. O resultado é uma forte tendência por parte do aprendiz a se limitar ao uso de NI para marcar lugar, em qualquer contexto. Trata-se, pois, de questão interessante para o ensino da língua japonesa para brasileiros.

Como referência para os significados das posposições a serem analisadas, escolhemos a obra de Shin Moriyama ${ }^{6}$, e em especial seu trabalho publicado em 2005, em que se apresenta a conclusão de suas pesquisas sobre as estruturas semânticas das posposições de caso GA, WO, NI e DE ao longo de nove anos. Vários outros autores, como Sugai (2001) e Mabuchi (2000), também analisam as posposições do japonês à luz da semântica cognitiva. Entretanto, destacamos Moriyama (2005) devido a sua obra ser, regular e constantemente, balizada na teoria dos casos de Langacker (2001a, 2001b), apresentando comparações

\footnotetext{
Pesquisador da Universidade Ochanomizu, dedicado a semântica cognitiva e aquisição de japonês como segunda língua. Sua obra se concentra no estudo das estruturas semânticas das posposições de caso do japonês e na aplicação das descobertas em estratégias de ensino de japonês para estrangeiros, em especial coreanos.
} 
detalhadas e esclarecendo as especificidades dos casos do japonês com relação aos universais ali propostos. Isso se constitui em uma grande vantagem para um estudo como o nosso, que se propõe a fazer comparações entre duas línguas, ainda que focalizando predominantemente o japonês. Além disso, Moriyama (2005) traz o que há de mais atual sobre as estruturas semânticas das posposições, revisando as colocações de vários autores de obras anteriores, inclusive os aqui mencionados.

Antes de expor as estruturas semânticas pelas quais nos guiaremos para a comparação que se fará neste trabalho, procederemos uma discussão de alguns aspectos, notadamente relacionados a NI e DE, relativos ao atual estado-da-arte das pesquisas sobre as posposições de caso japonesas em semântica cognitiva. Esperamos com isso antecipar-nos a algumas dúvidas que podem surgir sobre as organizações das estruturas semânticas aqui adotadas. Esses aspectos serão discutidos com mais detalhe nos seus respectivos capítulos.

\subsubsection{Particularidades dos casos do japonês}

Moriyama (2005) parte da teoria dos casos de Langacker (1991a, 1991b) para estabelecer os sentidos prototípicos das posposições de caso do japonês. Dessa perspectiva, a posposição GA corresponderia ao caso nominativo, DE, ao instrumental, WO, ao acusativo, e NI, ao dativo. No cenário da cadeia de ações recortado pelo sujeito da cognição, esses casos representam, respectivamente, o agente, o instrumento, o objeto direto e o objeto indireto (um participante fora da área de influência direta da força do agente, como veremos mais adiante).

Para Moriyama (idem, pp. 7-25), porém, Langacker deixa de explicitar três aspectos concernentes aos casos do japonês:

- Nessa língua, o caso instrumental não corresponderia a um papel dentro da cadeia prototípíca de ações, mas sim ao fundo do cenário onde as ações acontecem. 
- A cadeia de ações de Langacker dá conta da cognição de processos, mas ignora os fenômenos percebidos como ontológicos (constatação de existência ou localização). Esse aspecto é fundamental para a compreensão de NI.

- Tanto para os eventos processuais (cadeias de ações) como para os ontológicos (constatação de existência ou localização), o usuário do japonês pode escolher expressar a cena em termos "mais subjetivos" ou "mais objetivos", encaixando os fatos percebidos em estruturas diferentes, de acordo com o modo da percepção.

\subsubsection{Perspectiva processual e perspectiva ontológica em NI}

Moriyama (2005) organiza as várias acepções de NI que se encontram em dicionários, gramáticas e livros didáticos, em quatro sentidos básicos: alvo de movimento, origem de movimento, relação espacial e sujeito de experiência.

\begin{tabular}{|c|c|c|c|c|}
\hline $\begin{array}{l}\text { 11. watashi ga } \\
\text { eu NOM } \\
\text { Eu dei um liv }\end{array}$ & $\begin{array}{l}\text { Tarô ni } \\
\text { Taro NI } \\
\text { o para Taro. }\end{array}$ & $\begin{array}{l}\text { hon wo } \\
\text { livro ACS }\end{array}$ & $\begin{array}{l}\text { ageta. } \\
\text { dar-perf. }\end{array}$ & (alvo de movimento) \\
\hline $\begin{array}{l}\text { 12. watashi ga } \\
\text { eu NOM } \\
\text { Eu ganhei um }\end{array}$ & $\begin{array}{l}\text { Tarô ni } \\
\text { Taro NI } \\
\text { livro do Taro. }\end{array}$ & $\begin{array}{l}\text { hon wo } \\
\text { livro ACS }\end{array}$ & $\begin{array}{l}\text { moratta. } \\
\text { ganhar-perf. }\end{array}$ & (origem de movimento) \\
\hline $\begin{array}{l}\text { 13. tsukue no } \\
\text { mesa GEN } \\
\text { Há um livro e }\end{array}$ & $\begin{array}{l}\text { ue } n i \\
\text { cima NI } \\
\text { m cima da me }\end{array}$ & $\begin{array}{l}\text { hon ga } \\
\text { livro NOM } \\
\text { a. }\end{array}$ & $\begin{array}{l}\text { aru. } \\
\text { haver }\end{array}$ & (localização) \\
\hline $\begin{array}{l}\text { 14. [watashi ni] } \\
\text { eu NI }\end{array}$ & $\begin{array}{l}\text { kodomo ga } \\
\text { filhos NOM }\end{array}$ & $\begin{array}{l}\text { aru. } \\
\text { há }\end{array}$ & & (suj. de exper. [posse] $)^{7}$ \\
\hline
\end{tabular}

Os exemplos 11 e 12 exemplificam a perspectiva processual: ambos descrevem movimentos. Já 13 e 14 expressam uma perspectiva ontológica, ou seja, NI marca elementos captados de modo estático.

\footnotetext{
Exemplos de Moriyama (2005).
} 
O exemplo 13 mostra a constatação prototípica de existência, relacionando um objeto concreto a um espaço físico. Em 14, o uso de NI expressa a projeção no corpo humano do esquema de imagem CONTINENTE-CONTEÚDo: o objeto é marcado com NI como se estivesse contido no corpo do sujeito da cognição, ou em uma área de domínio em cujo centro se situa o sujeito. O rótulo sujeito de experiência é usado por Moriyama (2005) para reunir a acepção de sujeito de posse às de sujeito de percepção, de capacidade e de emoção. (Exemplos de todos esses usos serão apresentados no Capítulo 2.)

A semântica cognitiva, que busca estabelecer protótipos que irradiam as várias acepções pertencentes às categorias verbalizadas, propõe a pergunta sobre qual dessas perspectivas, a ontológica ou a processual, conteria o sentido central, prototípico, de NI.

Os participantes da cadeia de Langacker (1991a, 1991b) são, prototipicamente, seres humanos. Esse raciocínio implicaria em que, para o "caso NI", o dativo do japonês, as acepções que envolvem pessoas (alvo de benefício, origem de benefício ${ }^{8}$, agente da passiva, agente da causativa $^{9}$ etc.) estariam nas posições mais centrais de sua estrutura semântica. Em outras palavras, pela teoria de Langacker, NI representaria, prototipicamente, o caso do objeto indireto, na figura de uma pessoa dentro de um processo (cadeia de ações).

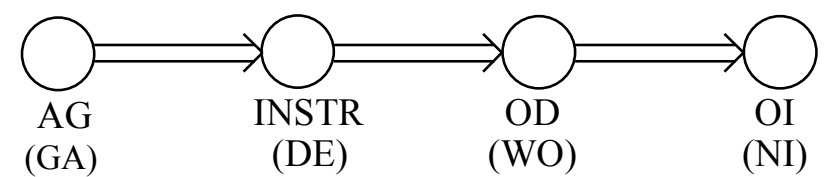

Figura 5: Cadeia de ações com as marcações dos casos do japonês em suas acepções prototípicas.

Ocorre que as acepções mais simples de NI, as que aparecem no início das entradas em dicionários e gramáticas e que são ensinadas nas primeiras lições dos cursos básicos, não são as que marcam pessoas, mas sim as que marcam pontos estáticos no tempo e no espaço. Dicionários geralmente são considerados uma fonte questionável de evidência para estudos

\footnotetext{
Argumentos (complementos) de verbos benefactivos, ou yarimorai dôshi.

9 Aquele a quem se manda ou permite fazer algo em construções causativas (shieki).
} 
científicos; não obstante, consideramos no mínimo sintomático o fato de a totalidade dos dicionários e materiais didáticos consultados colocarem a acepção marcador de lugar no primeiro lugar de suas listas de sentidos para NI. Desse ponto de vista, então, o protótipo deveria ser a marcação de local, ou seja, de um elemento estático (e portanto em uma perspectiva ontológica). Isso contraria a teoria dos casos de Langacker.

Essa divergência entre os sentidos de NI pode sugerir uma homonímia, uma vez que as acepções de NI como marcador de local são expressões do esquema de imagem CONTINENTECONTEÚDO, independentes das acepções relacionadas à DINÂMICA DE FORÇAS.

Entretanto, para a semântica cognitiva, se dois sentidos aparentemente distintos são incluídos em uma mesma categoria (sob o mesmo "rótulo", ou seja, vocábulo), é porque estão ligados entre si de alguma forma, sendo raras as homonímias propriamente ditas (LAKOFF, 1995 p. 151 et seq., entre outros). Diante disso, Moriyama deixa de questionar qual dos esquemas, DINÂMICA DE FORÇAS Ou CONTINENTE-CONTEÚDO, estaria no centro da estrutura semântica de NI, para ligar os dois a um super-esquema:

O ser humano, como sujeito da cognição, capta os fenômenos à sua volta processualmente, como movimentos (perspectiva processual), ou ontologicamente, de modo estático (perspectiva ontológica). As acepções do caso NI da perspectiva processual têm como traço comum a "oposição ativa ao movimento do caso GA", e as da ontológica, a "oposição passiva ao movimento do caso GA". Cada um desses protótipos estrutura uma categoria radial. Entretanto, no caso do japonês, o fato de os dois serem expressos pelo mesmo NI permite pensar que façam parte de algum super-esquema comum, reunidos em uma mesma categoria. Esse super-esquema seria o de oposição em relação ao caso GA (MORIYAMA 2004, p.85, grifo do autor).

De acordo com Moriyama, então, podemos admitir dois esquemas de imagem prototípicos para NI: um relacionado a uma perspectiva processual, de acordo com o que Langacker estabelece que sejam os casos prototípicos, e outro relacionado a uma perspectiva ontológica, sem relação com uma cadeia de ações. O usuário do japonês inclui os dois na 
mesma categoria devido à percepção de ambos como marcadores de um elemento oposto e independente daquele marcado com GA.

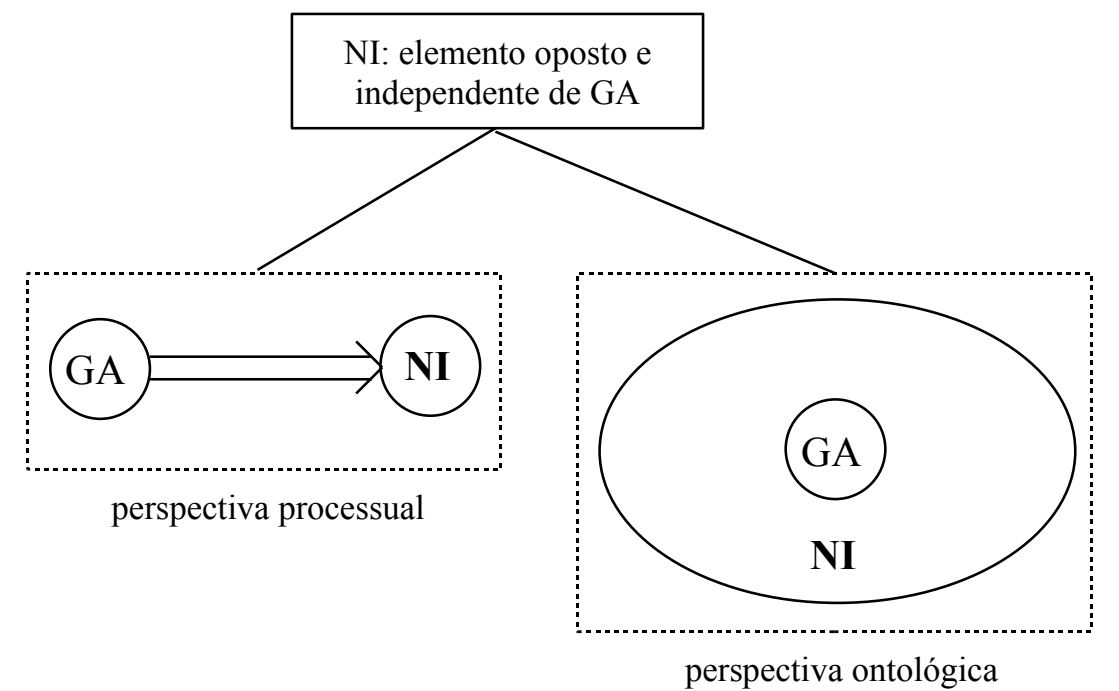

Figura 6: Os dois esquemas de imagem relacionados a NI e o super-esquema.

\subsubsection{Perspectiva objetiva e perspectiva subjetiva em NI}

Os exemplos 11 a 14, no item 1.4.1.1, mostram quatro acepções básicas de NI, duas processuais e duas ontológicas.

As acepções processuais, alvo de movimento e origem de movimento (exemplos $11 \mathrm{e}$ 12 respectivamente), indicam direções contrárias de deslocamento. Qual seria a relação que coloca as duas acepções na mesma categoria abarcada pela posposição NI?

Os exemplos 11 e 12 podem ser interpretados como referentes ao mesmo fato: o deslocamento de um livro entre duas pessoas. Em 11, o agente do deslocamento e o sujeito são o mesmo elemento. Já em 12, o sujeito é deslocado de sua posição de agente. Moriyama (2005, p. 63 et seq.) associa essa distinção a "graus de subjetividade" na percepção do sujeito da cognição. A acepção de origem de movimento é "mais subjetiva" por ser resultado de uma alteração dos papéis com relação ao perfil prototípico. 


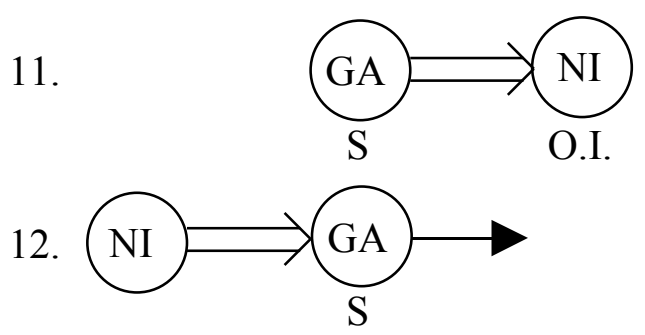

Figura 7: representações esquemáticas dos exemplos 11 e 12. As setas largas indicam transmissão de energia. A seta simples indica movimento resultante.

Essa oposição entre uma perspectiva "mais objetiva" e uma "mais subjetiva" também se aplica às acepções ontológicas de NI. Como observado no item anterior, o rótulo sujeito de experiência reúne as acepções de sujeito de posse, percepção, capacidade ou emoção. Complementaremos aqui a lista de exemplos apresentada anteriormente.
15. watashi ni wa Fujisan ga mieru. (suj. de experiência [percepção]) eu NI CTR monte Fuji NOM é visível Para mim, o Monte Fuji é visível.

16. Tanaka ni wa baiorin ga hikeru. (suj. de experiência [capacidade]) Tanaka NI violino NOM sabe tocar Tanaka sabe tocar violino.

17. watashi ni wa sono koto ga totemo ureshikatta. (suj. de experiência [emoção]) eu NI CTR esse fato NOM foi muito feliz Para mim esse fato foi muito feliz.

Observando os exemplos de 13 a 17 à luz do esquema de imagem CONTINENTECONTEÚDO, podemos dizer que, diferentemente do exemplo 13, nas frases de 14 a 17, quem faz o papel de continente é uma pessoa.

O exemplo 14 pode ser reescrito como em 18 (na página seguinte), mostrando que, para expressar essa relação entre o possuidor e o objeto possuído, o usuário do japonês tem duas opções: adotar uma perspectiva processual, como em 18, ou uma ontológica, como em 14, colocando a si mesmo como o continente no esquema de imagem CONTINENTE-CONTEÚDo. 
Esta última seria uma expressão "mais subjetiva" do fenômeno captado.

$$
\begin{array}{lll}
\text { 18. watashiwa } & \text { kodomo wo } & \text { motte iru } \\
\text { eu TOP } & \text { filhos ACS } & \text { ter-cont. } \\
\text { Tenho filhos. } & &
\end{array}
$$

Em suma, para cada uma das perspectivas, processual ou ontológica, o usuário da língua ainda pode acrescentar uma lente mais objetiva ou mais subjetiva. A Tabela 1 organiza as acepções de NI dentro dessas perspectivas.

Tabela 1. Acepções de NI.

\begin{tabular}{|c|c|c|c|}
\hline \multicolumn{2}{|c|}{ perspectiva processual } & \multicolumn{2}{c|}{ perspectiva ontológica } \\
\hline objetiva & subjetiva & objetiva & subjetiva \\
\hline alvo de movimento & origem de movimento & localização & suj. de experiência \\
\hline
\end{tabular}

\subsubsection{DE: o caso instrumental em japonês}

Moriyama (2005, p. 7) destaca o fato de DE servir como marcador de lugar na maioria de suas acepções e questiona se a acepção de instrumento é protótipica para DE. Em vez disso, o autor propõe que, se o cenário prototípico tem figura e fundo, o DE prototípico destaca o fundo, diante do qual os participantes (figuras) interagem.

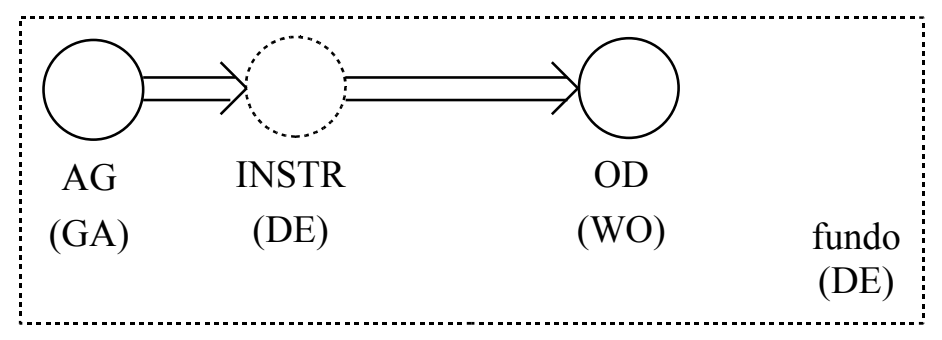

Figura 8. Representação gráfica do sentido prototípico de DE, inspirada em Moriyama (2005)

Esse raciocínio pode ser contra-intuitivo para o aprendiz brasileiro que esteja acostumado a associar primeiramente NI a lugar e DE a instrumento, ligando este último ao português COM; a acepção de instrumento pode parecer mais simples, e portanto é mais fácil 
crer que seja a prototípica. No entanto, encontramos dois argumentos que dão suporte à posição de Moriyama.

O primeiro argumento é histórico: DE é derivado da posposição NITE, que no japonês clássico já tinha a função de marcar o lugar onde se passa uma atividade. As outras funções, como marcar instrumento propriamente dito, causa, etc., também presentes no DE atual, são todas provenientes de NITE (MATSUMURA, 1999, MABUCHI 2000).

O segundo argumento é tipológico: o caso instrumental do japonês não se expressa de modo análogo ao da maioria das línguas do mundo. Lakoff e Johnson (1995, p. 176) constatam que, nas línguas naturais, "salvo raras exceções, a mesma palavra ou instrumento gramatical que indica companhia também indica instrumento", em uma manifestação da metáfora INSTRUMENTOS SÃO COMPANHEIROS, apontada pelos autores como uma das metáforas convencionais produzidas pela experiência corporal humana. O japonês não é coerente com essa metáfora: companhia é marcada exclusivamente com a posposição TO, e instrumento, com DE, também exclusivamente. Isso indica que em japonês o destaque do participante instrumento na cadeia de ações é menor que em outras línguas.

Em suma, embora possa parecer contra-intuitivo, principalmente para o usuário nãonativo do japonês, é razoável admitir que DE, prototipicamente, marca o caso do fundo do cenário, e não de um participante na cadeia de ações. O fundo prototípico é um local físico, e o traço semântico comum a elementos concretos e abstratos que servem como fundo é o de ser condição que permite a ação. Isto é, as acepções de instrumento, causa, etc. podem ser consideradas extensões do protótipo local, uma vez que todas marcam condições para a realização das ações destacadas (MORIYAMA, 2005, p. 8). 


\subsection{Resumo: introdução}

O caráter polissêmico dos nexos representa um dos desafios da aquisição de uma língua estrangeira. Isso nos motiva a buscar uma organização das correlações entre preposições do português e posposições do japonês, visando apoiar de alguma forma o ensino de japonês para aprendizes lusófonos. Esse é o objetivo deste trabalho.

Limitamos o escopo da nossa análise às posposições NI, DE e WO porque a comparação desses três "locativos" com base em suas propriedades semânticas é de notável interesse para o ensino de japonês para brasileiros.

Como referencial teórico geral, adotamos a semântica cognitiva por considerarmos que se trata de um meio eficaz para se identificar conjuntos razoavelmente organizados e bem definidos de acepções para elementos de sentido complexo como são nossos objetos de análise.

Como referência específica para as posposições do japonês, adotamos o trabalho de Moriyama (2005). Um dos motivos dessa escolha é a consistência de Moriyama com a teoria de Langacker (1991a, 1991b), o que facilita a comparação entre línguas distintas, pela possibilidade do cotejo de uma língua específica com as previsões de uma teoria universalizante. O outro motivo é que Moriyama apresenta os resultados mais atuais já publicados sobre posposições à luz da semântica cognitiva.

Antes de apresentarmos as estruturas semânticas dos objetos de análise a fim de proceder as comparações, observamos três aspectos relativos às estruturas semânticas de NI e $\mathrm{DE}$, que à primeira vista poderiam gerar questionamentos por parte de professores e aprendizes brasileiros da língua japonesa.

O primeiro aspecto é a questão da atribuição do status de protótipo a uma das 
acepções de NI. Uma vez que não existem dados empíricos para se determinar a primazia do esquema de imagem CONTINENTE-CONTEÚDO (acepções ontológicas) sobre o de DINÂMICA DE FORÇAS (acepções processuais), ou vice-versa, admitiremos que a categoria representada por NI una esses dois esquemas prototípicos no super-esquema: NI marca um elemento oposto $e$ independente daquele marcado por GA.

O segundo aspecto é a observação de uma polaridade entre perspectivas mais objetivas e mais subjetivas nas acepções de NI. Do ponto de vista processual, as acepções que colocam o sujeito como origem do movimento estão em uma perspectiva objetiva; as que colocam o sujeito como alvo são expressões mais subjetivas. Do ponto de vista ontológico, a acepção de sujeito de experiência coloca o sujeito como continente, sendo, assim, uma acepção mais subjetiva que a de relação de existência, em que o continente é um objeto externo ao sujeito.

O terceiro aspecto é o de que DE, que expressa o caso instrumental, em japonês, prototipicamente, não representa um dos participantes da cadeia de ações de Langacker, mas sim o fundo diante do qual a ação se desenrola. O conceito de fundo é uma esquematização das condições que permitem a realização de uma ação, sendo que o suporte primário para qualquer ação é um local. Dentro desse raciocínio, em japonês, a acepção de DE como instrumento pode ser considerada uma extensão do protótipo local. 


\section{As acepções de $\mathrm{Nl}$ e suas expressões em português}

Neste capítulo, apresentaremos detalhadamente a estrutura semântica da posposição de caso NI proposta por Moriyama (2005, p. 74-85), e sugeriremos uma revisão em alguns de seus pontos. Em seguida, a partir da estrutura revisada, investigaremos quais preposições do português o aprendiz lusófono pode mapear em NI, para cada uma de suas acepções.

\subsection{A estrutura semântica de NI}

Conforme descrito no capítulo anterior, as acepções de NI podem ser, primeiramente, expressões de uma perspectiva processual, conforme Langacker (1991a, 1991b) coloca os casos prototípicos, ou de uma perspectiva ontológica, como observa Moriyama (2005, pp. 63 et seq.). A perspectiva processual relaciona NI ao esquema de imagem DINÂMICA DE FORÇAS, sendo sua função prototípica marcar um participante ativo no domínio-alvo da cadeia de ações (uma pessoa que recebe um objeto). Já a perspectiva ontológica é aplicação do esquema de imagem CONTINENTE-CONTEÚDO, com NI marcando o continente.

Os dois esquemas de imagem estão ligados por um super-esquema, que dita que $N I$ marca um elemento oposto e independente daquele marcado com GA.

Dentro da perspectiva processual, temos as acepções básicas de alvo de movimento e origem de movimento, e na ontológica temos localização e sujeito de experiência (denominação comum das sub-acepções de sujeito de posse, suj. de percepção, suj. de capacidade e suj. de emoção).

Tanto na perspectiva processual como na ontológica, há acepções "mais objetivas" e outras "mais subjetivas" (MORIYAMA 2005, pp. 63-73).

Da perspectiva processual, a acepção alvo de movimento é mais objetiva que a de 
origem de movimento, pois faz respeitar os papéis da cadeia de ações prototípica: o sujeito da frase é o agente, e o objeto indireto é o receptor da ação. O uso de NI como marcador de origem de movimento inverte esses papéis. Da mesma forma, localização é mais objetiva, por colocar o sujeito da cognição como observador externo da imagem do local, enquanto sujeito de experiência faz coincidir o sujeito com o local (continente).

Podemos dizer então que, dentro da estrutura semântica de NI, na perspectiva processual, alvo de movimento é acepção prototípica e origem de movimento é periférica, e na perspectiva ontológica, local de existência é prototípica e sujeito de experiência é periférica.

$\mathrm{Na}$ figura 1 temos uma representação gráfica dos elementos básicos da estrutura semântica de NI, com o super-esquema ligando os ramos das acepções processuais e ontológicas.

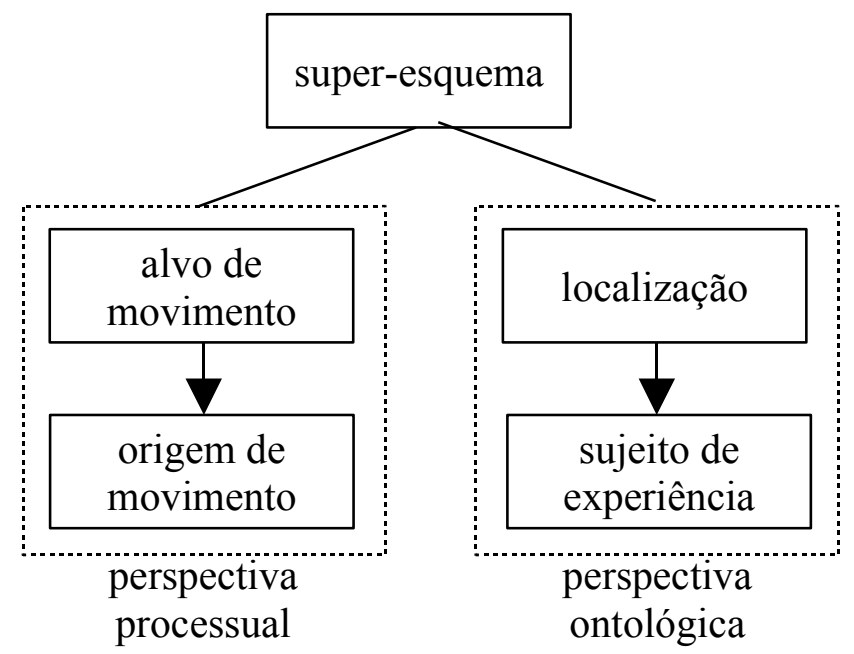

Figura 1. Estrutura semântica básica de NI, segundo Moriyama (2005)

Nos itens a seguir veremos essas acepções mais detalhadamente, especificando as ligações entre elas dentro de cada um dos dois ramos. 


\subsubsection{O ramo processual}

O que viemos chamando até aqui de "acepções básicas" contêm apenas os sentidos que uma posposição pode acrescentar a um participante do cenário. Uma acepção mais detalhada deve conter, além do sentido que a posposição acrescenta, os tipos de participantes a que ela pode se ligar.

Para organizar as acepções da perspectiva processual (alvo e origem de movimento), Moriyama (2005) classifica os participantes em pessoas (seres animados), objetos (seres inanimados) e locais. De acordo com o modelo de casos de Langacker (2001a, 2001b), acepções ligadas a pessoas ocupam posições mais centrais. Objetos e locais, nessa ordem, integram acepções mais afastadas do protótipo.

Os movimentos indicados por NI são classificados como concretos ou abstratos. Vejamos os exemplos abaixo, com NI marcando alvo de movimento.

1. tomodachi ni hon wo ageru. (concreto) amigo NI livro ACS dar

Dou um livro para o amigo.

2. gakusei ni nihongo wo oshieru. (abstrato) estudantes NI japonês ACS ensinar

Ensino japonês para os estudantes.

Em 1, temos um movimento concreto, um deslocamento físico de um objeto material. Já em 2, temos um movimento abstrato, a transmissão de conhecimento. O mesmo ocorre na acepção de origem de movimento.

3. tomodachini hon wo morau. amigo NI livro ACS ganhar

(concreto)

Ganho um livro do amigo.

4. senseini nihongo wo osowaru. professor NI japonês ACS ser ensinado

Tenho lições de japonês com um professor.

(*Sou ensinado japonês pelo professor) 
Moriyama (2005) destaca ainda um tipo de sub-acepção, chamada de movimento metafórico. Essa classificação se refere ao sentido de resultado de transformação, em que NI marca o resultado como se este fosse um alvo.

5. mizu wo koorini suru. água ACS gelo NI fazer

*fazer água em gelo

Transformar água em gelo.

6. mizuga koorini naru.

água NOM gelo NI tornar-se

A água torna-se (em) gelo.

Em suma, para as acepções da perspectiva processual, Moriyama (2005) classifica os participantes como pessoas, objetos ou locais, e os movimentos como concretos, abstratos ou metafóricos, dependendo do caráter mais concreto ou mais abstrato dos elementos ligados. Para situar as acepções em termos de distância do protótipo, essas classificações podem ser combinadas em uma matriz.

\begin{tabular}{|l|l|l|l|}
\hline \multicolumn{1}{|c|}{ participante } & pessoa & objeto & local \\
\hline movimento & & & \\
\hline concreto & & & \\
\hline abstrato & & & \\
\hline metafórico & & \\
\hline
\end{tabular}

Figura 2. Matriz usada por Moriyama (2005) para organizar as acepções de NI

A matriz prevê os possíveis desdobramentos de cada uma das acepções processuais. $\mathrm{O}$ resultado são 18 possibilidades hipotéticas de acepções para NI: nove combinações dos participantes com os graus de concretude do movimento, multiplicados pelas duas acepções processuais.

Esse sistema permite determinar com precisão até que ponto existem extensões para os 
protótipos processuais de NI. De fato, ao se testar cada uma das possibilidades hipotéticas de acepção da posposição, pode-se constatar que nem todas se realizam no uso da língua. Dentro da acepção de origem de movimento, no nível concreto, NI pode marcar pessoa e objeto, mas não $l o c a l^{10}$ :

7. tomodachi ni tegami wo moratta.
amigo NI carta ACS recebi

(origem: pessoa)

Recebi uma carta de um amigo.

8. kaminariniwa odoroita. trovão NI CTR assustei-me Assustei-me com o trovão.

9. a) *kunini tegamiwo moratta. (origem: local) país NI carta ACS recebi (sem tradução)

b) kuni kara tegami wo moratta. país ABL carta ACS recebi Recebi uma carta do [meu] país.

10. tomodachi ni hon wo karita. amigo NI livro ACS peguei emprestado

(origem: objeto) Peguei o livro emprestado de um amigo.

\begin{tabular}{|c|c|c|}
\hline $\begin{array}{l}\text { 11. a) *gakkô ni } \\
\text { escola NI } \\
\text { (sem tradução) }\end{array}$ & $\begin{array}{l}\text { hon wo } \\
\text { livro ACS }\end{array}$ & $\begin{array}{l}\text { karita. } \\
\text { peguei emprestado }\end{array}$ \\
\hline $\begin{array}{l}\text { b) gakkô kara hon wo } \\
\text { escola ABL } \\
\text { Peguei o livro emprest }\end{array}$ & $\begin{array}{l}\text { karita. } \\
\text { livro ACS } \\
\text { stado da escola. }\end{array}$ & peguei emprestado \\
\hline
\end{tabular}

Também não há extensões metafóricas para origem de movimento. Moriyama (2005, pp. 81-82) não explica essa afirmação, provavelmente por considerá-la óbvia, na condição de usuário nativo do japonês. Neste trabalho, entretanto, cremos que seja oportuno analisar esse fato. Será mais conveniente expor a análise após dissecarmos as sub-acepções possíveis; assim, ela será apresentada dentro do item 2.2.1.

De todo modo, podemos dizer que a teoria aplicada por Moriyama (2005) ajuda a prever os limites das possibilidades de acepções processuais de NI, e por isso será adotada 10 Alfonso (1974, p. 41) confirma explicitamente essa constatação. 
como guia para nossas comparações.

\subsubsection{O ramo ontológico}

O ramo ontológico tem menos desdobramentos que o processual.

A perspectiva mais objetiva é representada pela acepção de localização, que, segundo Moriyama (2005, pp. 63-85), englobaria quatro sub-acepções: local, horário ou data, referência de localização e referência de gradação.
12. tsukue no ue ni honga aru. (local) mesa GEN cima NI livro NOM haver Há um livro em cima da mesa.
13. jûji ni neru. dez horas NI dormir
Durmo às dez horas.
(horário) escola NI é perto
É perto da escola.
(referência de localização)
14. gakkôni chikai.
15. kono sozai wa netsu ni tsuyoi. (referência de gradação) Este material TOP calor NI forte * este material é forte em calor Este material é resistente ao calor.

\subsubsection{Acepções objetivas do ramo ontológico}

A acepção de localização indica prototipicamente um local - um espaço físico, tridimensional, onde algo se situa. Esse uso é representado pelo exemplo 12.

A sub-acepção de horário (exemplo 13) resulta da aplicação da metáfora convencional HORÁRIOS SÃo LOCAIS (LAKOFF, 1999), ou seja: o domínio espacial, tridimensional, é projetado no domínio temporal, linear.

A sub-acepção referência de localização (exemplo 14) é estabelecida por Moriyama (2005, p.77) com base na seguinte interpretação: o objeto a ser localizado é situado em uma escala de distância em relação ao elemento marcado com NI, que é um ponto de referência. 
Essa localização relativa, no exterior do elemento que seria o continente, seria extensão do conceito de localização dentro do continente (sub-acepção de local).

Consideramos contra-intuitiva essa explicação. A acepção ontológica prototípica de NI se expressa em termos do esquema de imagem continente-Conteúdo. Mas da forma como Moriyama (2005, p.69) conceitualiza o sentido de NI nos exemplos 14 e 15 (traduzida graficamente na Figura 3), o sujeito da cognição localizaria o ente observado em algum ponto definitivamente fora da área demarcada como continente. Parece-nos uma abstração consideravelmente complexa, para a qual proporemos uma alternativa, embasada nos parágrafos que seguem.

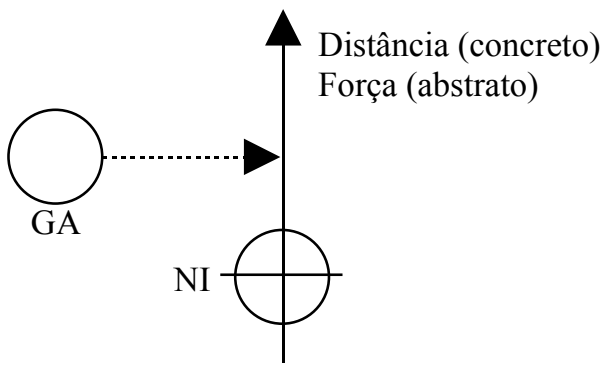

Figura 3. Gráfico de referência de localização e de gradação, segundo Moriyama (2005, p. 69)

Cremos que o uso de NI nesse caso pode estar relacionado à perspectiva processual. $\mathrm{O}$ conceito de "localização próxima" pode ser motivado pela imagem do movimento de aproximação a um alvo. Se não, vejamos os dois dados a seguir.

Primeiro: de um levantamento feito através do site de buscas Google Japan, comparamos os números de ocorrências das seqüências:

1a: eki ni chikai ("perto da estação")

1b: eki kara chikai (idem, com a posposição trocada pela de caso ablativo)

2a: eki ni tooi ("longe da estação") 
2b: eki kara tooi (idem, caso ablativo)

As combinações de eki ("estação") com chikai ("perto") e tooi ("longe") foram escolhidas por se tratar de um fator importante na localização de estabelecimentos comerciais e residências em todo o território japonês, onde a malha ferroviária é altamente desenvolvida. Julgamos, assim, poder obter um corpus suficientemente extenso para nosso propósito.

A Tabela 1 resume os resultados encontrados nas comparações dos números de ocorrências entre $1 \mathrm{a}$ e $1 \mathrm{~b}$ e entre $2 \mathrm{a}$ e $2 \mathrm{~b}$. As quantidades são aproximadas, porque o mecanismo de busca do site arredonda os números grandes. Pode-se notar pelos resultados que o uso de NI para localizar um elemento distante da estação (seqüência 2a) é muito raro. Nessa situação, KARA (caso ablativo), é preferência quase unânime.

Tabela 1. Resultados de buscas de posposições ligando eki (estação) a chikai (perto) e tooi (longe). Ferramenta de busca: Google Japan. Data da busca: 15/12/2006.

\begin{tabular}{|c|c|c|c|c|}
\hline Seqüências & Ocorrências & Proporção & \multirow{2}{*}{\multicolumn{2}{|c|}{ Total $1 a+1 b$}} \\
\hline 1a eki ni chikai & 503.000 & $43 \%$ & & \\
\hline 1b eki kara chikai & 673.000 & $57 \%$ & 1.176 .000 & $100 \%$ \\
\hline 2a eki ni tooi & 122 & $0,05 \%$ & \multicolumn{2}{|c|}{ Total $2 a+2 b$} \\
\hline 2b eki kara tooi & 250.000 & $99,95 \%$ & 250.122 & $100 \%$ \\
\hline
\end{tabular}

Segundo: não é possível usar NI quando, no lugar de um adjetivo como chikai (perto), especifica-se uma distância, como, digamos, 100 metros. Nesse caso, apenas KARA é cabível.

Esses dados sugerem que a opção por NI não tem a ver somente com o fato de o elemento estar localizado em um ponto, mas é fortemente influenciada, se não decidida, pela noção de proximidade ao referencial. O predomínio do uso de KARA indica que a noção de movimento pode estar relacionada à noção de posição relativa: o elemento prototípico marcado por KARA é um local onde se inicia um deslocamento. Esse raciocínio sugere que 
NI estaria para um alvo de aproximação assim como KARA estaria para um referencial de afastamento, ainda que se trate de localizar entes estacionados.

Diante disso, sugerimos que esta acepção de NI seja chamada de referencial de proximidade, por seu uso ser possível apenas junto com o adjetivo chikai (perto), e que seja tratada como um caso especial da acepção de alvo de movimento, situada dentro do ramo processual da estrutura semântica. Podemos encaixá-la na matriz de acepções com o rótulo local alvo de movimento abstrato. Com isso, a sub-acepção referência de localização deixa de fazer parte da estrutura de NI. Nossa proposta pode ser representada pela Figura 4.

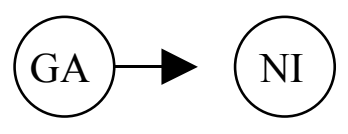

Figura 4. Representação gráfica da acepção referência de proximidade.

A seta curta indica falta de contato entre os elementos.

Quanto à sub-acepção de referência de gradação (exemplo 15) proposta por Moriyama (2005, p.77), cremos que também caibam críticas. Segundo o autor, esse uso de NI resulta de uma abstração da relação de referência de localização. Netsu (calor) seria tomado pelo sujeito da cognição como referência de uma escala de força, para situar o sozai (material) em uma posição relativa (ver Figura 3, na página 44).

Nossa hipótese é de que no uso que estamos discutindo, NI só relaciona um elemento qualquer a um agente de agressão física, como o calor, o frio, produtos químicos, impactos, etc. Para verificar a hipótese, apresentamos a constatação que segue. Frases como os exemplos 16 e 17 abaixo não ocorrem em japonês:

$\begin{array}{lll}\text { 16. *kono sozai wa } & \text { nedan ni } & \text { takai. } \\ \text { Este material TOP } & \text { preço NI } & \text { é alto } \\ \text { (sem tradução) } & & \end{array}$



17. *kono sozai wa hinshitsu ni takai.
Este material TOP qualidade NI é alto
(sem tradução)

Para produzir frases gramaticais e aceitáveis que relacionem gradações a referências, devemos substituir NI por GA, o que resulta nos exemplos abaixo.
18. kono sozai wa nedanga takai.
Este material TOP preço NOM é alto
Este material é de alto preço.
19. kono sozai wa
hinshitsu ga
takai.
Este material TOP qualidade NOM é alto
Este material é de alta qualidade.

Acreditamos que, não o exemplo 15 (na página 43), mas sim os exemplos 18 e 19, é que apresentam verdadeiras referências de gradação, que são marcadas com GA. O elemento marcado com NI no exemplo 15 poderia ser chamado mais apropriadamente, talvez, de "alvo de resistência".

Observamos ainda que em japonês são usuais frases como:

\section{0. kono shakai wa jakushani kibishii. \\ esta sociedade TOP fracos NI é rigoroso \\ Esta sociedade é rigorosa (para) com os fracos.}

\section{1. kono sozai wa hadani yasashii. \\ Este material TOP pele NI é gentil}

Este material é gentil (para) com a pele. (não agride a pele)

Os exemplos 20 e 21 denotam atitudes para com alvos. Podemos considerá-las como um uso situado na acepção de alvo de movimento; no caso, um movimento abstrato, como é uma atitude.

Construções como a do exemplo 15 são motivadas pelo esquema de imagem DINÂMICA DE FORÇAS, isto é, netsu ni tsuyoi (é forte [para] com o calor) equivale a netsu ni makenai (não perde [em uma "disputa" de forças] para o calor). O exemplo 15, portanto, é análogo aos 
exemplos 20 e 21 , podendo-se dizer talvez que em um grau maior de abstração, pelo fato de o adjetivo tsuyoi (forte) projetar uma característica humana em um ser inanimado (o material).

Diante disso, propomos mais um rearranjo na estrutura semântica de NI desenhada por Moriyama (idem, ibidem). Em nossa interpretação, o elemento marcado com NI no exemplo 15 é um objeto alvo de movimento abstrato, uso este também situado no ramo de acepções processuais de NI. Para esta dissertação, portanto, a sub-acepção referência de gradação deixa de existir.

\subsubsection{Acepções subjetivas do ramo ontológico}

A acepção mais objetiva de local, que delimita um continente observado de fora pelo sujeito, motiva acepções mais subjetivas, em que o próprio sujeito é o continente de objetos concretos (relação de posse) ou abstratos (percepção, capacidade, emoção). Moriyama agrupa os sujeitos de posse, percepção, capacidade e emoção sob o rótulo de sujeito de experiência.

22. [watashini] kodomoga aru. (sujeito de posse) eu NI filhos NOM há

Tenho filhos.

*há filhos em mim

23. watashi ni wa Fujisan ga mieru. (sujeito de percepção) eu NI CTR monte Fuji NOM é visível *em mim, o Monte Fuji é visível Para mim, o Monte Fuji é visível.

24. Tanakani baioringa hikeru. (sujeito de capacidade) Tanaka NI violino NOM sabe tocar Tanaka sabe tocar violino.

25. watashi ni wa sono koto ga totemo ureshikatta. (sujeito de emoção) eu NI CTR esse fato NOM foi muito feliz Para mim esse fato foi muito feliz.

A relação de posse (exemplo 22) é expressa por NI delimitando uma área imaginária em cujo centro está o próprio sujeito, e que contém os objetos sobre os quais este tem domínio, conforme ilustra a Figura 5. 


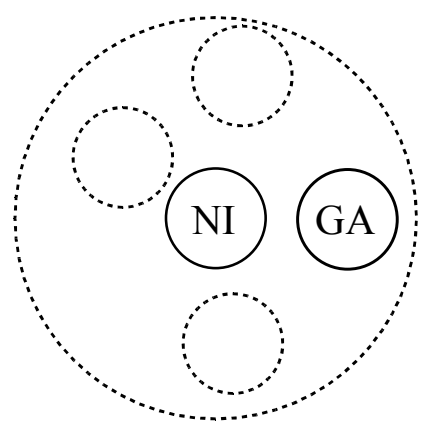

Figura 5. Representação gráfica das acepções de sujeito de posse e de percepção

Essa área imaginária também pode se aplicar aos objetos percebidos pelas sensações (exemplo 23). O que chamamos de "campo de visão" (expressão com análogos em japonês e outras línguas) é a área imaginária onde estão contidos os objetos que vemos. Em um nível mais abstrato, também podemos colocar em um campo os objetos percebidos intelectualmente (exemplo: wakaru - compreender). Essas expressões se enquadram na acepção sujeito de percepção.

A acepção de sujeito de capacidade (exemplo 24) expressa o sujeito como continente de objetos ainda mais abstratos, e pode ser entendida como extensão de sujeito de percepção.

Para situar usos como o do exemplo 25 (suj. de emoção), Moriyama (2005, p. 84) considera que as emoções são propriedades humanas de natureza semelhante à das percepções (de fato, ambas são sensações), e assim postula que essa acepção, do mesmo modo que sujeito de percepção, é extensão de sujeito de posse. 


\subsubsection{Resumo: estrutura semântica de NI}

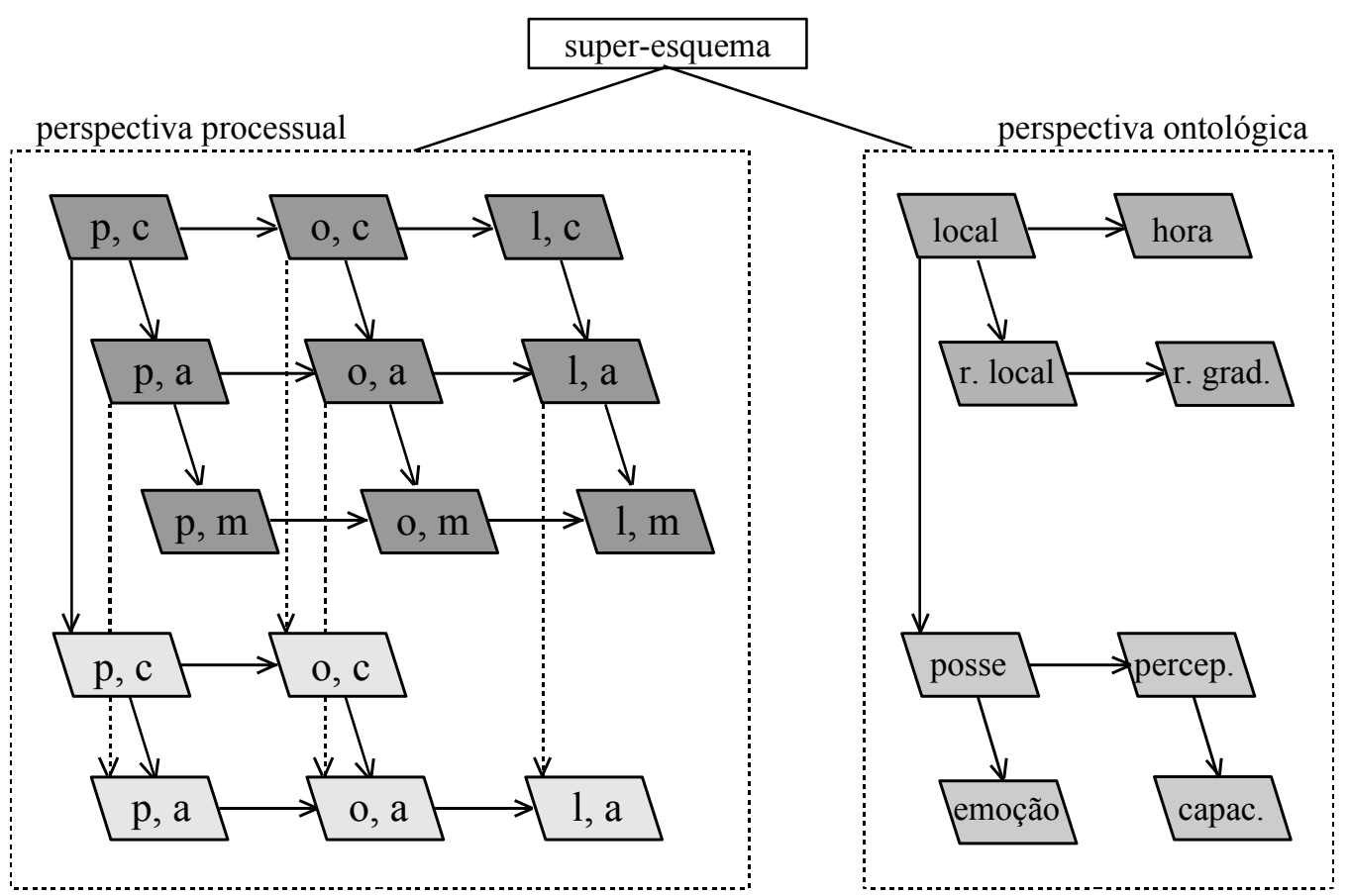

Figura 6. Estrutura semântica de NI segundo Moriyama (2005, p. 85). Os pares ordenados no diagrama da perspectiva processual são as combinações de participantes (Pessoa, Objeto e Local) com movimentos (Concreto, Abstrato e Metafórico). Os blocos com hachuras mais claras representam as acepções mais subjetivas.

A estrutura semântica de NI é consideravelmente complexa, com uma larga rede de extensões separada em dois ramos semanticamente distintos, o das acepções da perspectiva processual e o das acepções da perspectiva ontológica. Dentro de cada um desses dois conjuntos, ainda se pode enxergar uma separação entre acepções de motivação mais objetiva e outras mais subjetivas; no caso da perspectiva processual, a diferença entre uma e outra relaciona-se com nada menos que a direção do movimento considerado.

Do desenho apresentado na Figura 6 acima, sugerimos, neste trabalho, que não se considerem as acepções referência de localização e referência de gradação como folhas do ramo ontológico, mas sim como nervuras de folhas do ramo processual, mais especificamente no ramo de alvo de movimento. Em nossa visão, o que Moriyama (2005) chama de referência 
de localização é uma referência de proximidade, com aplicação por demais restrita para ser considerada uma acepção distinta de outras, e não está relacionada necessariamente com o fato de o ente localizado estar estacionado. Já o que o autor chama de referência de gradação só se aplica à relação entre um objeto "agressor" e outro que resiste ou não à agressão, não cabendo outros tipos de gradação para esse uso de NI. Trata-se, contudo, de divergência que não nos impede de prosseguir adotando Moriyama como referencial teórico para nossas análises.

A classificação de participantes e de movimentos usada por Moriyama para subdividir as acepções processuais de NI, prevendo os limites de suas extensões metafóricas, traz grande contribuição ao ensino do japonês, na medida em que fornece bases para que o aprendiz previna-se contra o uso de "combinações absurdas", como marcar com NI o local de partida de um deslocamento. Esse detalhamento da estrutura de NI traz ainda uma outra contribuição interessante: ajuda a determinar com notável precisão quais são as preposições de uma outra língua que correspondem a NI, em quais contextos. Os quadros que exporemos nos itens a seguir mostram a complexidade da rede de correspondências que há entre preposições do português e a posposição NI.

\subsection{Mapeamento de preposições do português em NI}

Não temos conhecimento, até o momento, de estudos que detalhem estruturas semânticas das preposições do português, os equivalentes das posposições japonesas, nos mesmos moldes e com o mesmo nível de detalhamento de Moriyama (2005). Não obstante, com base no que vimos até agora sobre NI, podemos supor, com razoável segurança, que não encontraremos uma preposição em português cuja estrutura seja igual à de NI; outrossim, podemos crer que sejam pouco freqüentes estruturas semânticas idênticas entre nexos de duas línguas tão diferentes entre si como o japonês e o português. As semelhanças limitam-se aos 
sentidos prototípicos; raramente encontraremos coincidências exatas entre os conjuntos de acepções que eles podem motivar.

É a noção intuitiva desse fato, entre outros, que faz o usuário da língua em geral dizer que o aprendiz deve procurar "pensar na língua-alvo" (no caso, "pensar em japonês") para usar a língua da maneira mais próxima possível à dos falantes nativos. Somos obrigados a encontrar alternativas ou simplesmente abandonar expressões da língua materna (marcas de gênero e número, infinitivo pessoal, vários tempos verbais etc.) e aceitar outras da língua-alvo (verbos auxiliares benefactivos, auxiliares de contagem etc.) que não encontram correspondências mútuas.

Todo aprendiz lusófono de japonês pode perceber, já nas primeiras fases dos estudos, que NI em português ora corresponde a $a$, ora a $e m$, ora a para, etc. Essa inconsistência entre os conjuntos de nexos (para não falar do restante dos recursos) das duas línguas é um obstáculo a ser superado pelo aprendiz adulto. Cremos, assim, que a metodologia de ensino de uma língua não deva ignorar as características da língua materna do aprendiz. Dentro desse contexto, os estudos comparativos são de grande valia.

O que se fará nesta parte do trabalho é um levantamento das possíveis formas de se expressar em português os sentidos contidos na posposição NI. Com isso, pretendemos esclarecer:

- Com que preposições do português pode se expressar cada acepção de NI;

- Quais acepções de NI exigem que o aprendiz lusófono do japonês assimile formas diferentes daquelas com que está acostumado para expressar objetos de cognição.

Nesse contexto, daqui em diante diremos que é possível mapear uma ou mais preposições em NI quando, a determinado uso dessa posposição, corresponder uma ou mais 
preposições do português com o mesmo sentido prototípico. Por exemplo, à acepção alvo de movimento estão associadas as preposições para e $a$. O aprendiz geralmente pode mapear para/a em NI nessa acepção. Entretanto, nem todas as sub-acepções de NI permitirão esse mapeamento; há casos em que para uma mesma sub-acepção podem ser usadas várias preposições. Diremos então que não é possível um mapeamento consistente, o que exigirá um grau de esforço um pouco maior do aprendiz. Ainda, haverá sub-acepções para as quais o português pedirá preposições com sentido prototípico completamente distinto do de alvo de movimento, ou estruturas frasais distantes do exemplo em japonês. Diremos nesses casos que essas sub-acepções não encontram correspondência no português, o que exigirá que o aprendiz "abra a mente" para a estrutura semântica de NI, abandonando totalmente a preposição ou construção que seria usada em português.

\subsubsection{Acepções do ramo processual}

\subsubsection{Alvo de movimento e suas extensões}

A acepção de alvo de movimento permite relacionar pessoas, objetos e locais a movimentos concretos, abstratos ou metafóricos, gerando nove "sub-acepções". As preposições com sentidos equivalentes a NI nesta acepção são $a$ e para.

\section{Pessoa alvo de movimento concreto}

26. tomodachi ni hon wo ageru. amigo NI livro ACS dar

Dou um livro a/para o amigo.

27. a) shachô ni au. diretor NI encontrar ?encontrar o diretor Ir ao encontro do diretor.

b) shiranai hito ni butsukaru. desconhecido NI trombar Trombar em um desconhecido. 
Para expressar "movimento concreto em direção a pessoa" em português, temos as preposições $a$ e para.

Dentro dessa acepção, no caso de verbos transitivos, pode-se traduzir NI como a/para em qualquer caso. Já os verbos intransitivos ${ }^{11}$ não permitem uma associação tão simples.

Uma tradução mais comum em português para o exemplo 27 a seria "encontrar-se com o diretor", e para 27b seria "trombar com um desconhecido". Acontece que o japonês permite distinguir se, no ato de encontrar-se $(a u)$, um participante se desloca aonde o outro fica estacionado, pelo uso de NI, ou se os dois se deslocam para um mesmo ponto, pelo uso da posposição TO - que marca o caso comitativo. Já encontrar em português ou rege com (que corresponde a TO), ou é transitivo direto. E ainda, se o movimento resultar em um contato físico, como em $27 \mathrm{~b}$, o português preferirá a preposição em.

Com isso, no caso de verbos como au (encontrar) e outros que permitem referir deslocamentos recíprocos, o aprendiz lusófono poderá tender a usar TO, por corresponder diretamente a com. Destacar a possibilidade de um dos participantes se deslocar unilateralmente dependerá de esforço consciente.

Já no caso de o encontro resultar em contato físico, há a coincidência de NI ser equivalente a em, embora em uma acepção diferente (marcador de local/continente). Isto é, o aprendiz que conhece essa equivalência entre NI e em como locativos não precisará de esforço para utilizar a posposição corretamente na acepção de alvo de movimento com contato físico.

${ }_{11}$ Esclarecemos que, no contexto dos estudos da língua japonesa, um verbo é considerado "transitivo" (tadôshi) somente se aceita objeto direto. Verbos que não aceitam objeto direto (mesmo que aceitem um indireto, como au [encontrar-se]) são chamados de jidôshi, termo normalmente traduzido para o português como "intransitivo". Em termos semânticos, os jidôshi representam movimentos realizados exclusivamente pelo sujeito, enquanto os tadôshi representam movimentos aplicados pelo sujeito diretamente a um objeto. 


\section{Pessoa alvo de movimento abstrato}

28. gakusei ni nihongo wo oshieru. estudantes NI japonês ACS ensinar

Ensinar japonês a/para os estudantes.

29. senmonka ni sôdan-suru.

especialista NI consultar

Consultar o especialista.

30. a) haha ni amaeru.

mãe NI abusar

?acomodar-se na mãe

Abusar [da boa-vontade] da mãe.

b) haha wo shinjiru

mãe ACS acreditar

Acreditar na mãe.

31. kono shakaiwa jakushani kibishii.

esta sociedade TOP fracos NI é rigoroso

Esta sociedade é rigorosa (para) com os fracos.

Mais uma vez, os verbos transitivos permitem ao aprendiz lusófono mapear sem titubear a ou para em NI.

Os intransitivos já não proporcionam a mesma facilidade, como mostra a comparação entre os exemplos 30a e 30b. As naturezas semânticas dos verbos em português e japonês nesse tipo de frase não se correspondem perfeitamente, e assim faz-se necessário conhecer a regência dos verbos um a um. Destacamos que ainda há casos em que o verbo em português pode reger um correlato de NI, mas seu equivalente em japonês não aceita essa posposição, como no exemplo $30 \mathrm{~b}$.

As orações em português com predicado constituído de adjetivo, dentro desta acepção, normalmente acompanham com (ou para com, em usos eruditos). Substituir com por para no exemplo 31 não resulta agramatical, mas é pouco usual.

Nesta sub-acepção, então, para as ações transitivas pode-se mapear a/para em NI, ao passo que as intransitivas não permitem um mapeamento consistente. Predicados constituídos 
de adjetivo exigirão que o aprendiz faça um esforço consciente, para associar com a NI.

\section{Pessoa alvo de movimento metafórico}

32. musuko wo meu filho ACS

ichininmae no otona $n i$

adulto independente NI

*farei meu filho em um adulto independente

Transformarei meu filho um adulto independente.

\section{3. musuko ga}

meu filho ACS

ichininmae no otona $n i$

adulto independente NI

Meu filho se tornará (em) um adulto independente. suru.

fazer

naru.

tornar-se

O participante marcado com NI nesta acepção é mais conhecido, nas gramáticas e dicionários, como "resultado de transformação". O estágio final de um processo é representado metaforicamente como alvo.

$\mathrm{Na}$ construção transitiva, o verbo suru (fazer) não permite uma tradução direta para o português. Já outros verbos como kaeru (transformar) o permitem, e assim como o japonês rege NI, o português rege em. Outros ainda, como trocar (kaeru, homônimo mas não homógrafo do anterior) ou substituir (torikaeru, okikaeru), em português regem por. As variações de regência param por aqui.

O mesmo ocorre com as ações intransitivas. O verbo naru deve ser traduzido como "virar" ou "tornar-se". As construções "virar em" ou "tornar-se em", embora possíveis, não são utilizadas com freqüência pela média dos falantes atuais do português. Já outros verbos como "transformar-se" (kawaru) regem em.

Para esta sub-acepção, em suma, nas ações transitivas, com exceção da construção $N I$ suru, que deve ser tratada como expressão idiomática, pode-se mapear em ou por em NI. Nas intransitivas, NI naru deve ser tratada como expressão idiomática e pode-se mapear apenas em em NI. 


\section{Objeto alvo de movimento concreto}

34. keitai ni sutorappu wo tsukeru.

celular NI livro ACS prender

Prenderei um cordão no/ao celular.

35. penkini hokoriga tsuita.

tinta NI poeira NOM fixou-se

?Grudou poeira na tinta.

Fixou-se poeira na tinta.

Takahashi et al. (2003) chamam esta sub-acepção de "local onde algo se gruda" (kuttsuku tokoro). De fato, ela se refere invariavelmente a movimentos que resultam em contato.

Do mesmo modo que na sub-acepção de pessoa alvo de movimento concreto, pode-se mapear sem restrições uma mesma preposição do português na posposição NI para descrever ações transitivas. A diferença é que, em português, movimentos que resultam em contato com objetos indiretos (fixar, prender, grudar, bater etc.) tendem a ser descritos com o uso de em ( $a$ também é possível, apesar de ser de uso mais erudito: "fixar a", "prender a" etc.).

Quanto às ações intransitivas, embora a tradução mais próxima da estrutura original em japonês seja encontrada apenas no português falado (que, como observamos anteriormente, não serve de referência para o aprendiz comum), permanece o mapeamento consistente de em em NI. Outras preposições não podem ser associadas a NI neste caso.

Resumindo, nesta sub-acepção, mapeia-se em ou $a$ em NI para as ações transitivas e em para as intransitivas.

\section{Objeto alvo de movimento abstrato}

36. gêmuboi ni hamaru.

Game-Boy NI viciar-se

Viciar-se em Game-Boy. 
37. a) kono sozai wa hadani yasashii.

Este material TOP pele NI é gentil

Este material é gentil com a pele. (não agride a pele)

b) kono sozai wa netsu ni tsuyoi.

Este material TOP calor NI forte

*este material é forte em calor

Este material é resistente ao calor.

38. a) geemuboi ni akiru.

Game-Boy NI enjoar

Enjoar de Game-Boy.

b) shizen chiyuryoku wo shinjiru

poder de cura natural ACS acreditar

Acreditar no poder da cura natural.

Esta acepção é parcialmente análoga à de pessoa alvo de movimento abstrato. A diferença é que, em japonês, esta acepção só contém ações intransitivas (ações que não admitem objeto direto).

A comparação entre os exemplos 36 e 38 a mostra novamente que nem todos os verbos que em japonês regem NI terão correspondentes em português regendo preposições que indicam alvo ou continente (em, a, para). Ou seja, o aprendiz precisa associar conscientemente a noção de alvo de movimento a determinados verbos para usar a posposição correta.

O exemplo 38b (análogo ao exemplo 30b) nos relembra que há verbos no português que regem em, mas cujos correspondentes em japonês não aceitam NI. Devido a essas diferenças, portanto, não se pode fazer um mapeamento consistente de em em NI.

No caso de orações om adjetivo no predicado, o uso de $a$, para ou com também varia muito de acordo com o adjetivo usado.

Em suma, esta sub-acepção não permite um mapeamento consistente de quaisquer preposições em NI, porque uma mesma ação (enjoar, por exemplo) pode ser classificada em japonês como pedindo um alvo (e reger NI), mas em português pedir uma origem (e reger de), 
entre outras discordâncias.

\section{Objeto alvo de movimento metafórico}

\begin{tabular}{|c|c|c|}
\hline $\begin{array}{l}\text { 39. mizu wo } \\
\text { água ACS } \\
\text { *fazer águ } \\
\text { Transform }\end{array}$ & $\begin{array}{l}\text { koori ni } \\
\text { gelo NI } \\
\text { m gelo } \\
\text { igua em g }\end{array}$ & $\begin{array}{l}\text { suru. } \\
\text { fazer }\end{array}$ \\
\hline $\begin{array}{l}\text { 40. mizu ga } \\
\text { água NOM }\end{array}$ & $\begin{array}{l}\text { koori } n i \\
\text { gelo NI }\end{array}$ & $\begin{array}{l}\text { naru. } \\
\text { tornar-se }\end{array}$ \\
\hline
\end{tabular}

Esta acepção é análoga à de pessoa alvo de movimento metafórico (resultado de transformação). Com exceção das associações de NI com suru (fazer) e naru (virar/tornar-se), pode-se mapear em ou por em NI para as ações transitivas, e apenas em para as intransitivas.

\section{Local alvo de movimento concreto}

$\begin{array}{llll}\text { 41. tsukue no } & \text { ue ni } & \text { hon wo } & \text { noseru. } \\ \text { escrivaninha GEN } & \text { cima NI } & \text { livro ACS } & \text { colocar } \\ \text { Colocar um livro em cima da escrivaninha. } & \end{array}$

42. a) kekkonshiki ni iku. casamento NI ir

?Ir em um casamento Ir a/para um casamento.

b) gakkou ni bentô wo motteiku. escola NI lanche ACS levar ?levar lanche na escola Levar lanche à/para a escola

$\mathrm{Na}$ acepção local alvo de movimento concreto, a diferença entre as regências não se decide pela transitividade, mas pelo tipo de movimento. Em português, o uso de em para marcar os complementos de verbos como ir ou levar não é aceito na linguagem escrita culta. Já na linguagem falada não se pode negar que ocorra, mas não é a essa que o estudante brasileiro recorre para fazer comparações e mapeamentos, mesmo inconscientemente ${ }^{12}$.

12 Na prática de ensino de japonês, durante explicações gramaticais, procuro freqüentemente fazer analogias com usos do português falado para cobrir certas diferenças que há entre o japonês e o português escrito culto. Em muitos casos os alunos reagem franzindo o cenho, por considerarem o português falado como "errado", 
Colocar, de um lado, e ir e levar, de outro, exprimem percepções de movimentos de amplitudes claramente distintas. Em termos mais simples, ir e levar são movimentos "muito mais amplos" que colocar.

Dentro desta acepção, então, podemos mapear em em NI para os movimentos de amplitude pequena, e $a$ ou para em NI para os movimentos de amplitude grande. Estritamente do ponto de vista da aquisição do japonês, pode-se dizer que para esta acepção é possível mapear a/para ou em indistintamente em NI.

\section{Local alvo de movimento abstrato}

43. tooi furusato $n i \quad$ omoi wo haseru.

distante terra natal NI pensamento ACS conduzir

Conduzir o pensamento à distante terra natal.

44. yôyaku nihon ni narete kita.

finalmente Japão NI acostumei-me

?finalmente acostumei-me no Japão

Finalmente acostumei-me ao Japão.

45. gakkôni chikai.

escola NI é próximo

É próximo à escola.

Nesta acepção, frases expressando ações transitivas ("levar um pensamento/idéia/sentimento a um local") são relativamente pouco freqüentes. De todo modo, pode-se mapear a/para em NI do mesmo modo que na acepção de local concreto.

Quanto a ações intransitivas, em nível abstrato, apesar de o correspondente em português de nareru (acostumar-se) permitir o uso da preposição com, outros verbos com sentido semelhante (adaptar-se, aclimatar-se etc.) permitem apenas o uso de $a$. Trata-se portanto de uma exceção que pode ser desprezada.

Moriyama (2005) nos lembra que NI atribui ao objeto um caráter de independência em 
relação à ação ao sujeito. Tanto o japonês nareru e seus correlatos como o português acostumar-se etc. contêm o traço da imperturbabilidade do objeto diante da estranheza inicial do sujeito, que deve se conformar, no sentido mais amplo da palavra.

O exemplo 45 constitui uma aplicação especial desta sub-acepção, que chamamos de referencial de proximidade. Conforme discutido no item 2.1 - "A estrutura semântica de NI", sustentamos que se trata de uma extensão do sentido de objeto alvo de movimento abstrato. Em frases como o exemplo 45 não cabe outro adjetivo além de chikai (perto). O uso de ni tooi (longe) é extremamente raro, provavelmente motivado por uma tendência de um grupo de usuários da língua no sentido de valorizar simetrias. Assim como é mais freqüente em japonês marcar o referencial de distância com KARA (ablativo), em português normalmente usa-se de. Entretanto, quando se trata do adjetivo próximo, pode ser usada a preposição $a$, excepcionalmente.

Podemos concluir para esta acepção que para ações transitivas pode-se mapear em NI as preposições $a /$ para, e para as intransitivas, a preposição $a$.

\section{Local alvo de movimento metafórico}

46. miyako wo Kyôto ni suru. capital ACS Quioto NI fazer ?transformar a capital em Quioto

Fazer de Quioto a capital.

47. miyako ga Kyoto ni naru. capital NOM Quioto NI tornar-se ?a capital tornar-se (em) Quioto A capital passa a ser Quioto.

Em japonês, assim como pessoa e objeto, um local também pode ser tomado como "resultado de transformação". Porém, para traduzir frases como os exemplos 46 e 47, é necessário reelaborar sua estrutura no português, e para utilizar essas construções em japonês, 
o usuário não-nativo deve "estar totalmente livre" de sua língua materna.

Em suma, as construções japonesas que expressam esta acepção não encontram equivalente em português.

\section{Resumo: mapeamentos na acepção alvo de movimento}

A Tabela 2 resume as preposições do português que podem ser mapeadas em NI para cada sub-acepção de alvo de movimento. Pontos de interrogação indicam que não é possível um mapeamento consistente. Sinais de "x" indicam que a construção não tem equivalente direto no português. A expressão não há entre parênteses indica que a acepção hipotética, gerada apenas pelo cruzamento das variáveis da matriz, não existe em japonês.

Quanto ao uso das preposições em português, barras separam preposições que podem ser usadas indistintamente, e pontos-e-vírgulas separam aquelas de uso mutuamente exclusivo.

Tabela 2: preposições que podem ser mapeadas em NI na acepção alvo de movimento

\begin{tabular}{|c|c|c|c|c|c|c|}
\hline participante & \multicolumn{2}{|c|}{ pessoa } & \multicolumn{2}{|c|}{ objeto } & \multicolumn{2}{|c|}{ local } \\
\hline movimento & trans. & intrans. & trans. & intrans. & trans. & intrans. \\
\hline concreto & \multirow{2}{*}{ a/para } & em*;? & $\mathrm{em} / \mathrm{a}$ & em & \multicolumn{2}{|c|}{ a/para; em** } \\
\hline abstrato & & $?$ & (não há) & $?$ & $\mathrm{a} /$ para & $\mathrm{a}$ \\
\hline metafórico & em/por & em & em/por & em & \multicolumn{2}{|c|}{$\mathrm{x}$} \\
\hline
\end{tabular}

* no caso de o movimento resultar em contato físico. Nos outros casos, não há mapeamento consistente.

** o português associa a/para a movimentos mais amplos e em a movimentos menos amplos

\subsubsection{Origem de movimento e suas extensões}

A acepção de origem de movimento engloba os casos em que NI marca o agente de um movimento (agente da passiva etc.) ou a causa de um fato.

Em comparação com alvo de movimento, o uso de NI com essa acepção é limitado. Da matriz de combinações entre tipos de participantes e graus de abstração do movimento, não ocorre o par movimento concreto - local, e tampouco os usos metafóricos. 
Em português, o agente da passiva é geralmente acompanhado de por, e a causa, de de (como em "morrer de desgosto"), ou $a$, em alguns casos ("ferido a bala").

\section{Pessoa origem de movimento concreto}

48. tomodachi ni hon wo morau.

amigo NI livro ACS ganhar

Ganhar um livro do amigo.

49. a) ginkôin ga hannin ni korosareta.

bancário NOM criminoso NI matar-pasv.-perf.

O bancário foi morto pelo criminoso.

b) ginkôinga hannin ni kubiwo kirareta.

bancário NOM criminoso NI pescoço ACS cortar-pasv.-perf.

O bancário teve o pescoço cortado pelo criminoso.

Estão dentro desta acepção os sentidos comumente descritos como "agente de benefício" (argumento de verbos benefactivos que indicam recebimento: morau e itadaku) e "agente da passiva".

Quando a ação envolve um objeto que transita entre o agente e o paciente, o correspondente de NI em português é de, como mostra o exemplo 48.

Quando a ação afeta diretamente o paciente, a preposição a ser mapeada em NI é por.

Objetos como o que aparece no exemplo 49b ( $k u b i$, pescoço) não devem nos enganar: reforcemos que o "objeto que transita entre os participantes" deve ser um terceiro elemento, que se desloca entre o agente e o paciente. Não é o caso do exemplo $49 \mathrm{~b}$.

Em suma, para esta sub-acepção, quando se trata do deslocamento de um objeto do agente para o paciente, pode-se mapear de em NI. Quando o paciente é afetado diretamente pela ação do agente, NI corresponde a por. 


\section{Pessoa origem de movimento abstrato}

50. senseini nihongo wo osowaru. professor NI japonês ACS ser ensinado-perf.

??ter o japonês ensinado por um professor

* ser ensinado japonês por um professor

Receber lições de japonês de um professor.

\section{1. karewa kokumin ni ai-sarete iru.}

ele TOP cidadãos NI amar-pasv.-cont.

?Ele é amado dos cidadãos.

Ele é amado pelos cidadãos.

A construção do exemplo 50 não encontra correspondência direta no português. É interessante notar que não há barreira para a tradução quando se trata de movimento concreto (ver exemplo 48). O aprendiz lusófono deverá então "pensar em japonês" para estender a esta sub-acepção o uso da anterior.

Quando a ação recai diretamente sobre o paciente, entretanto, o aprendiz ainda pode se apoiar no português e mapear por em NI, sem restrições.

\section{Pessoa, objeto ou local como origem de movimento metafórico}

Moriyama (2005, pp. 81-82) afirma que não ocorre o uso de NI com esse sentido. Para usuários nativos de japonês, essa discussão talvez seja realmente desnecessária, mas, neste trabalho, cremos que caiba uma tentativa de explicação.

As sub-acepções de origem de movimento são extensões daquelas de alvo de movimento. Como vimos anteriormente, o alvo de movimento metafórico é o resultado de uma transformação. Em outras palavras, o estado final de um processo de transformação é representado metaforicamente como um alvo. Dentro desse raciocínio, na acepção de origem de movimento, NI marcaria o estado original do objeto transformado.

De fato, NI não é utilizado com essa função, e em português também não ocorrem 
expressões com esse sentido.

\section{Objeto origem de movimento concreto}

52. a) kusuri ni tasukerareru. remédio NI ser salvo

*ser salvo do remédio.

Ser salvo pelo remédio.

b) byouki ni shinu.

doença NI morrer

?Morrer por doença.

Morrer de doença.

c) yorokobi ni warau.

contentamento NI sorrir

?Sorrir por contentamento.

Sorrir de contentamento.
53. taifû ni ie wo tobasareru.
tufão NI casa ACS ser levada
*ter a casa levada do tufão.
Ter a casa levada pelo tufão.

Esta sub-acepção se refere a um objeto como causa de um fato concreto. Cabe observar que não importa se o objeto é concreto ou não.

Em português, nesse caso, a preposição por é exigida se o verbo estiver na voz passiva; se não, de é normalmente empregada. O verbo morrer constitui caso especial, aceitando por em construções estilizadas como "morrer pela espada", "morrer pela mão de Deus" etc.

\section{Objeto origem de movimento abstrato}

54. shakkin ni kurushinde iru. dívidas NI sofrer-cont.

*sofre pelas dívidas

* sofre das dívidas

Sofre com as dívidas.

55. a) ijime ni nayande iru.

maus-tratos NI sofrer -cont.

*sofre pelos maus-tratos

*sofre dos maus-tratos

Sofre com os maus tratos. 


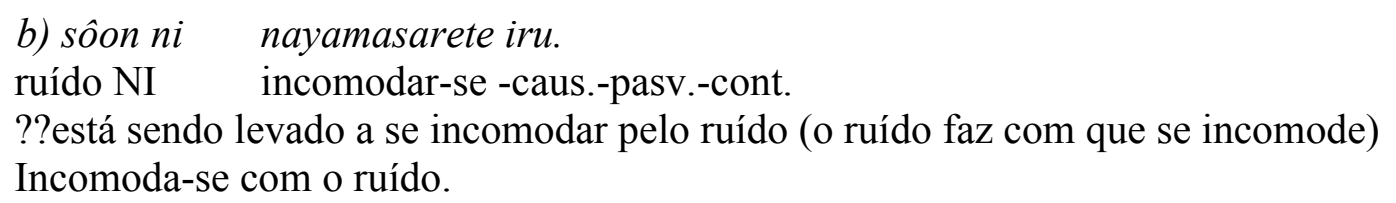

Em japonês, para indicar uma causa direta e simultânea à conseqüência, é mais comum o uso de DE (caso instrumental, com sentido esquemático de condição). Não obstante, NI também pode ser usado, como mostram os exemplos acima. Existe uma situação, porém, em que NI é obrigatório: são construções como a que aparece no exemplo 55b, em que o verbo está na forma passiva.

No mesmo contexto, o português obriga ao uso de com, que está mais próximo do DE do japonês, pois também indica o caso instrumental. Ainda, como mostra o exemplo 55b, em se tratando de movimentos abstratos, o português não permite colocar uma causa como agente em uma oração na voz passiva. Não é possível traduzir o exemplo 55b sem eliminar o "caráter de agente da passiva" de sôon (ruído) ou sem colocar a oração na voz ativa.

Para este uso de NI, portanto, o aprendiz lusófono tem de "abrir a mente", não encontrando apoio no português. Não convém admitir que com possa ser mapeado em NI, uma vez que tem sentido próximo ao de DE na acepção de condição. Ainda, mapeando com em DE para indicar causa direta e simultânea, o aprendiz produzirá as frases da forma como ocorrem com mais freqüência em japonês.

\section{Local origem de movimento concreto}

Não se usa NI como marcador de local de origem de movimento concreto. Essa afirmação também provavelmente dispensa explicações (Moriyama [2005, p.82] dispensouas), mas registraremos um comentário, como exercício de reflexão. Afinal, por que NI pode marcar uma pessoa ou um objeto como origem de movimento, mas não um local? 
Para começar, observemos uma diferença que existe entre os três tipos de participantes. Da análise das sub-acepções de origem de movimento vistas até aqui, podemos extrair que, como agente da passiva, uma pessoa pode ser agente do deslocamento de um objeto para o paciente, ou agir diretamente sobre este. Já um objeto não pode ser agente de movimento, podendo apenas protagonizar uma ação direta sobre o alvo, na condição de causa. Finalmente, um local não pode ser agente (ver também exemplos 7 a 11, no item 2.1.1 - "O ramo processual").

Verbos como receber (ukeru), ganhar (morau) etc. (classificados em português como transitivos diretos e indiretos, ou "bitransitivos"), ou verbos na voz passiva, fazem pressupor na origem do movimento um participante ativo. O local não tem essa característica.

Resta responder por que NI não pode indicar origem para verbos intransitivos. No caso dos "bitransitivos" ou verbos na voz passiva, NI pode acompanhar tanto o agente como o receptor porque esses verbos contêm em seu significado a direção do movimento. Verbos intransitivos, como $i k u$ (ir) e kuru (vir), não indicam por si sós essa direção, e portanto o uso indiscriminado de NI para destino e origem não faz sentido.

\section{Local origem de movimento abstrato}

56. kare wa daitokaini somatte itta. ele TOP metrópole NI tingir-se ir-perf.

Ele foi se tingindo pela metrópole (foi adquirindo características urbanas).

\section{Nihon ni nayamu.} Japão NI incomodar-se Incomodar-se com o Japão.

Moriyama (2005, p.82) escava o exemplo 56 acima ressaltando que "não é fácil encontrar esse tipo de frase; mesmo nessa amostra, o local deve ser interpretado como objeto, assim, 'metrópole' deve ser interpretada como 'o ambiente da metrópole', sob pena de um 
resultado agramatical".

Para estabelecer o mapeamento de preposições do português em NI neste caso, usamos como referência a sub-acepção objeto origem de movimento abstrato.

Aqui existe uma diferença importante entre local e objeto. Um objeto pode ser referido como causa pelo emprego da posposição DE, que indica caso instrumental/condição. Nesse contexto, objetos podem ser tomados como instrumentos, mas locais, não. A construção Nihon DE nayamu (ver exemplo 57) não permite a interpretação de que o Japão é a causa do incômodo.

Com isso, restam apenas as preposições com e por para se associar a NI nessa acepção. Em português o emprego de com ou de por depende da regência de cada verbo; apesar disso, em se tratando de local como origem de movimento abstrato, podemos mapear uma ou outra em NI sem distinção.

\section{Resumo: mapeamentos na acepção origem de movimento}

Diferentemente da acepção alvo de movimento, aqui não cabe o simples critério de transitividade da ação ${ }^{13}$ para definição do mapeamento. Como vimos durante a análise, no caso de o participante em questão ser uma pessoa, é necessário levar em conta se a ação envolve ou não um terceiro objeto transitando entre o agente e o paciente. $\mathrm{Na}$ Tabela 3 , distinguiremos esse traço pelas expressões "com trânsito" e "sem trânsito". Ainda, se o participante marcado for um objeto, entra em cena a distinção da voz passiva ou ativa do verbo.As convenções da Tabela 3 são as mesmas da Tabela 2.

13 Ver nota 2, no item 2.2.1 - "acepções do ramo processual", para uma definição de transitividade na língua japonesa. 
Tabela 3: preposições que podem ser mapeadas em NI na acepção origem de movimento

\begin{tabular}{|l|c|c|c|c|c|}
\hline \multicolumn{1}{|c|}{ participante } & \multicolumn{2}{|c|}{ pessoa } & \multicolumn{2}{c|}{ objeto } & local \\
\hline movimento & com trânsito & sem trânsito & v. ativa & v. passiva & \\
\hline concreto & $\mathrm{de}$ & \multirow{2}{*}{ por } & $\mathrm{de}$ & por & (não há) \\
\cline { 2 - 5 } abstrato & $\mathrm{x}$ & & $\mathrm{x}$ & com/por \\
\hline metafórico & \multicolumn{2}{|c|}{ (não há) } & \multicolumn{2}{c|}{ (não há) } & (não há) \\
\hline
\end{tabular}

\subsubsection{Acepções do ramo ontológico}

\subsubsection{Acepções objetivas: local e horário/data}

Em português, a preposição que marca a localização de um ente no espaço é $\mathrm{em}$. Para localizar um evento no tempo, usa-se em para dias e unidades maiores, e $a$ para as unidades menores - as horas.

\section{Local}
58. tsukue no ue ni honga aru. mesa GEN cima NI livro NOM haver Há um livro em cima da mesa.

A correspondência entre NI e em é tão simples e direta que somos tentados a afirmar categoricamente que local é o sentido prototípico de NI, do qual partiriam inclusive as acepções processuais. Não existem, porém, até o momento, dados empíricos para apoiar essa afirmação, que contraria a teoria de Langacker (2001a, 2001b), segundo a qual os marcadores de caso se referem prototipicamente a pessoas.

A localização prototípica, isto é, o local físico, é indicado em português pela preposição em, mais comumente, ou $a$, em uma forma mais erudita. Em outras palavras, na acepção de local, pode-se mapear em/a em NI. 


\section{Horário/data}

59. a) juji ni neru.

dez horas NI dormir

Durmo às dez horas.
b) tsuitachi $n i$
hajimaru.
dia primeiro NI
começar
Começa no dia primeiro.

Em português, tradicionalmente se reserva a preposição $a$ para marcar horário, e em para marcar data ( $a$ em textos mais eruditos). O japonês não faz essa distinção.

Assim, para datas ou horários, pode-se mapear $a$ ou em em NI.

\section{Resumo: mapeamentos nas acepções objetivas}

Na acepção de localização no espaço (local), pode-se mapear em em NI.

$\mathrm{Na}$ acepção de localização no tempo (horário/data), o aprendiz lusófono deve agrupar $a$ (usado para horários) e em (usado para datas) dentro de uma só categoria, digamos, "ponto no tempo", para associá-las a NI. A Tabela 4 resume os mapeamentos possíveis.

Tabela 4: preposições que podem ser mapeadas em NI nas acepções ontológicas subjetivas

\begin{tabular}{|c|c|}
\hline local & horário/data \\
\hline $\mathrm{em}$ & $\mathrm{a} / \mathrm{em}$ \\
\hline
\end{tabular}

\subsubsection{Acepções subjetivas: os quatro tipos de sujeito de experiência}

Continuaremos trabalhando com a premissa de que o local ou continente em um cenário ontológico em português é marcado com em, para a comparação com os usos de NI nesta acepção.

\section{Sujeito de posse}

60. watashini kodomoga aru. eu NI filhos NOM há

*em mim há filhos

Eu tenho filhos. 
O uso de NI com esta acepção não encontra correspondência na língua portuguesa. Mesmo em japonês, trata-se de uma construção rara, não só pelo uso de aru no lugar de $i r u^{14}$, mas também pelo uso de NI no lugar de WA (posposição de tópico).

\section{Sujeito de percepção}

\section{1. watashi ni wa Fujisan ga mieru.}

eu NI CTR monte Fuji NOM é visível

*em mim, o Monte Fuji é visível

Para mim, o Monte Fuji é visível.

Apesar de a tradução de frases como a do exemplo 61 não exigir mudanças estruturais profundas - podemos manter a ordem dos termos e o caso nominativo de "Monte Fuji" -, não podemos associar NI à preposição em, embora o significado desta tenha mais a ver com a perspectiva ontológica.

O aprendiz deverá mapear para (ou $a$ ) em NI nesta acepção. Cabe notar que para é equivalente a NI na acepção processual. Isso permitirá um mapeamento sem entraves, mas pode gerar resistência do aprendiz lusófono quanto ao caráter ontológico desta acepção em japonês.

\section{Sujeito de capacidade}

62. a) Tanaka ni baioringa hikeru.

Tanaka NI violino NOM sabe tocar ?para Tanaka é possível tocar violino Tanaka sabe tocar violino.

b) Tanakaniwa baioringa hikenai.

Tanaka NI CTR violino NOM sabe tocar ?para Tanaka, não é possível tocar violino Para Tanaka, é impossível tocar violino.

14 Em japonês, para o mesmo sentido de haver, são usados dois verbos: aru, para referir a existência ou localização de seres inanimados, e iru, para seres animados. Para reforçar o sentido de posse (existência no "círculo interno" do sujeito), em contraste com o de simples existência, usa-se aru mesmo para seres animados. Em geral, esse uso de aru se refere a parentes próximos do sujeito. 
A construção do exemplo 13b, em japonês, é usada com mais freqüência em frases negativas. Em português, também é mais direta a tradução da frase negativa.

Mantém-se nesta sub-acepção o mapeamento de para/a em NI, em mais uma manifestação da coincidência referida no item acima.

\section{Sujeito de emoção}

63. watashi ni wa sono koto ga totemo ureshikatta. (sujeito de emoção) eu NI CTR esse fato NOM foi muito feliz

Para mim esse fato foi muito feliz.

A estrutura de frases como o exemplo 63 pode ser mantida na tradução em português, ressalvando-se, novamente, a necessidade do emprego de para/a em português.

\section{Resumo: mapeamentos nas acepções subjetivas}

Com exceção da sub-acepção de sujeito de posse, que não encontra correspondência no português, todas as outras permitem mapear para em NI. A preposição para, em português, assim como NI, também é usada para marcar alvo de movimento, o que facilita a transposição dessa preposição em NI pelo aprendiz.

Tabela 5: preposições que podem ser mapeadas em NI nas acepções ontológicas subjetivas

\begin{tabular}{|c|c|c|c|}
\hline Suj. posse & Suj. percepção & Suj. capacidade & Suj. emoção \\
\hline$x$ & para/a & \multicolumn{2}{|c|}{ para } \\
\hline
\end{tabular}




\section{As acepções de DE e suas expressões em português}

O termo usado por Takahashi et al. (2003, p. 27) para se referir ao caso marcado pela posposição DE resume seus sentidos mais concretos: locativo-instrumental. Basicamente, DE marca a localização de um evento (diferente de NI, que marca a localização de um ente), ou marca o instrumento ou meio usado pelo agente para realizar uma ação. Embora DE não seja tão complexo quanto NI, também é associado a uma lista extensa de acepções. Moriyama (2005) organiza os usos de DE conforme a lista de exemplos a seguir.

local

1. sono kaigiwa amerika de hirakareru.

essa reunião TOP Estados Unidos DE realizar-se-pasv.

Essa reunião será realizada nos Estados Unidos.

local abstrato

2. kare no keikakudewa kono mondai wa atsukawarete inai. ele GEN plano DE CTR este problema TOP lidar-pasv.-cont.-neg. No plano dele, este problema não é contemplado.

\section{área demarcada}

3. eberesuto wa sekai de ichiban takai yama desu.

Everest TOP mundo DE o mais alto montanha-afirm.

O Everest é a montanha mais alta do mundo.

limite de quantidade

4. sanjû-nin de shimekirimasu.

trinta pessoas DE fecha

Fecharemos com trinta pessoas.

agente de movimento

5. sono jiken wa keisatsu de sôsa-shite imasu.

Esse incidente TOP polícia DE investigar-cont.

Esse incidente está sendo investigado pela polícia.

tempo

6. shokujino ato de, benkyô wo shimasu. refeição GEN depois DE estudo ACS fazer

Depois das refeições, eu estudo.

período de tempo

7. seichôno kateide ichijitekini arawareru genshôdesu. desenvolvto GEN processo DE temporariamtemanifestar-se fenômeno-afirm. É um fenômeno que se manifesta temporariamente no processo de desenvolvimento.

limite de tempo

8. natsuyasumi wa ashita de owaridesu. 
férias de verão TOP amanhã DE fim-afirm.

As férias de verão, amanhã terminam.

\section{instrumento}

9. nihonjin wa hashide mono wo taberu. japonês TOP hashi DE coisa ACS comer

Os japoneses comem coisas com hashi.

meio

10. karewa kôkûbin de tegamiwo okutta.

ele TOP via aérea DE carta ACS enviar-perf.

Ele enviou a carta por via aérea.

material

11. kono tsukue wa ki de dekite imasu.

esta escrivaninha TOP madeira DE ser feita-cont.

Esta escrivaninha é feita de madeira.

elemento estrutural

12. nihon bunka no tokuchô to iu daimoku de ronbun wo kakimashita.

cultura japonesa GENcaracterística CIT tema DE tese ACS escrever-perf

Escreveu uma tese com o tema "características da cultura japonesa".

causa

13. byôki de gakkôwo yasumu.

doença DE escola ACS faltar

Faltar à escola por doença.

razão

14. sô iu ten de omoshiroi to omou.

esse ponto DE interessante CIT achar

Acho interessante por causa desse ponto.

fundamento

15. shiken no kekkade handan-suru.

prova GEN resultado DE decidir

Decidiremos com base no resultado da prova.

motivação/objetivo

16. shucchô de Ôsakae itta.

viagem de negócios DE Osaka ALT ir-perf.

Foi a Osaka em viagem de negócios.

situação/aspecto de agente de movimento

17. yûgohan wa jibun de tsukutte tabemasu.

jantar TOP sozinho DE fazer ADT comer

O jantar, eu faço e como sozinho.

situação/aspecto de paciente de movimento
18. chiisana oto de
ongaku wo
kikimashita.
volume baixo $\mathrm{DE}$
música ACS ouvir-perf.
Ouvi a música com volume baixo.

\section{situação/aspecto de movimento ou evento}

19. mô-supiido de hashitte imasu. 
velocidade feroz DE correr-cont.

Corre a uma velocidade feroz.

A apresentação deste capítulo seguirá esta ordem: primeiramente, apresentaremos um resumo do raciocínio que fundamenta o desenho da estrutura semântica de Moriyama (2005) para a posposição de caso DE. Em seguida, procuraremos explicar mais detalhadamente as acepções da lista acima, descrevendo também como se expressam essas significações na língua portuguesa. No final, apresentaremos um resumo das preposições do português que podem ser mapeadas em DE, em cada uma de suas acepções.

\subsection{A estrutura semântica de $D E$}

Relembremos aqui as questões básicas que devem ser respondidas para a descrição de uma estrutura semântica, conforme a teoria da semântica cognitiva:

- Qual é o significado prototípico do elemento em questão, ou seja, o significado mais concreto, motivado por nossa experiência física?

- Quais são as acepções motivadas pelo protótipo, e como estão encadeadas?

- Qual é o super-esquema que une todas as acepções do elemento?

Em se tratando da posposição DE, a resposta da primeira questão apresenta um problema semelhante ao de NI.

No caso de NI, não há evidências suficientes até o momento para afirmar se a acepção de alvo de movimento é a prototípica, motivando a acepção de local; com isso, por ora, nos conformamos com o paralelismo entre o conjunto de acepções processuais e o de acepções ontológicas proposto por Moriyama (2005, p. 85).

No caso de DE, ficaríamos entre as acepções de instrumento e de local, não fosse a análise diacrônica pormenorizada de Mabuchi (2000) e a revisão de Moriyama (2005) da 
teoria de Langacker (1991a, 1991b), que expressa os casos em função de uma cadeia de ações.

Mabuchi (2000) faz um levantamento dos usos de DE desde o século XIV até os dias de hoje, e desenha uma estrutura das derivações semânticas de DE com base nos dados encontrados. O pesquisador conclui que o "uso essencial" (nas palavras do próprio Mabuchi, 基幹的用法 - kikanteki yôhô) de DE é como marcador de local; em seguida viriam os usos como marcador de meio e de situação/aspecto, e nos séculos XVI a XIX é que esses usos se desdobrariam na multiplicidade de acepções que existem no japonês moderno. Mabuchi ainda postula que as "características semânticas essenciais" (kikanteki imi tokusei) de DE sejam as de "marcar um participante passivo com relação à situação expressa pelo verbo" (doushi ga arawasu jitai e no shôkyokuteki san'yo) e de "marcar os limites de uma situação" (jôkyô no gentei).

Sendo DE uma posposição de origem bem conhecida, podemos admitir que as conclusões de Mabuchi nos aproximam consideravelmente do que seria o super-esquema de DE (com as "características semânticas essenciais") e do seu sentido prototípico (com o "uso essencial"). No entanto, seu trabalho ainda não esclarece as relações entre as diversas acepções de DE do ponto de vista cognitivo - de que modo as acepções estariam ligadas entre si, ou como uma acepção teria motivado outra(s). Passemos, então, às contribuições de Langacker (1991a, 1991b) e Moriyama (2005) para a questão.

A teoria de Langacker coloca os protótipos dos casos como sendo participantes de uma cadeia de ações. O caso instrumental marca um participante que está entre o agente (caso nominativo) e o objeto (caso acusativo). 


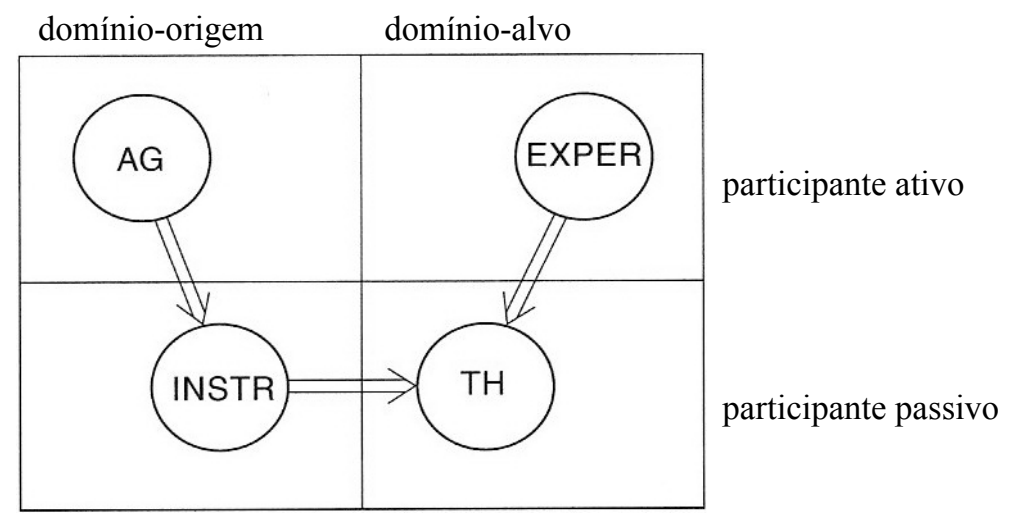

Figura 1. Cadeia de ações transitivas e seus participantes (Langacker 1991a, p. 327)

Entretanto, uma observação mais atenta da posposição DE do japonês mostra que dentre as diversas acepções de DE, apenas uma delas, a de marcador de instrumento propriamente dito (exemplo 9), se encaixa no protótipo postulado por Langacker. Moriyama (2005, p. 29) ressalta que a acepção de meio (exemplo 10) deve ser considerada como uma acepção separada de instrumento. A diferença entre os dois é que, enquanto o instrumento é um elemento que está situado entre o agente e o paciente, o meio não tem essa propriedade; não está entre os dois participantes, sendo, sim, parte do cenário. Para ilustrar, coloque-se o exemplo 9 na cadeia de ações expressa na Figura 1. O instrumento "hashi" está entre o agente "japoneses" e o paciente "coisas". Já em 10, "via aérea" não está entre "ele" e "carta"; o avião da "via aérea" entra em cena depois, como resultado, da ação do remetente sobre a carta. Em suma, o instrumento está dentro do fluxo de energia do sujeito para o objeto, e é um dos participantes da cadeia de ações, mas o meio tem um papel secundário, participando apenas indiretamente da ação, fazendo parte do fundo do cenário, em oposição às figuras que participam da cadeia de ações (MORIYAMA, 2005, p. 30).

Após esclarecer a diferença entre instrumento e meio, Moriyama postula que, assim como meio, todas as outras acepções de DE se referem ao fundo do cenário. Para entender 
essa colocação, é necessário obter uma compreensão mais ampla sobre o conceito de fundo.

Segundo Langacker (1991b), qualquer que seja o escopo recortado da rede de elementos que interagem no mundo externo, o fundo diante do qual as ações percebidas acontecem será sempre externo ao sujeito da cognição — em contraste com o fato de que o sujeito pode colocar a si próprio como um participante da cadeia.

Ocorre que, se os elementos que interagem no mundo externo são inumeráveis, os que podem compor o fundo do cenário recortado também o são. Assim, o sujeito da cognição, da mesma forma que coloca seu foco em determinados elementos dentre vários para destacar uma cadeia, deve fazer o mesmo tipo de seleção para compor o fundo. Em outras palavras, embora o sujeito da cognição observe o fundo de uma perspectiva necessariamente objetiva, a interpretação sobre qual elemento compõe esse fundo é subjetiva. É nesse sentido, segundo Moriyama (2005), que acepções diversas podem estar reunidas sob a mesma posposição DE. Assim, o super-esquema de DE é o elemento que expressa o fundo ou suporte sobre o qual se apóia a cadeia de ações. Esse elemento é escolhido pelo sujeito da cognição, e pode ser um local, horário, instrumento, material, situação/aspecto, etc.

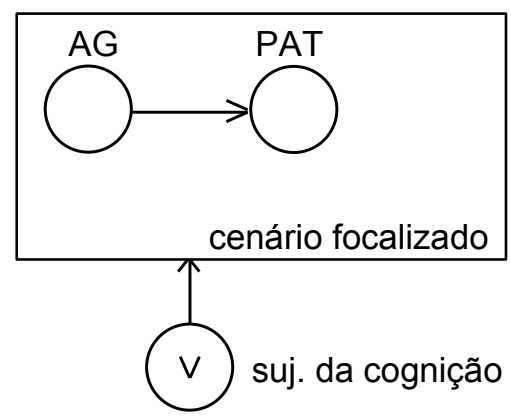

Figura 2. A relação entre o sujeito da cognição, o cenário selecionado e os participantes da ação.

Resta uma dúvida: a acepção de instrumento, reconhecida por Moriyama (2005, p. 30) como correspondente ao caso instrumental de Langacker, e portanto, como um participante da cadeia de ações — parte do primeiro plano, e não do fundo, seria uma exceção dentro do 
conjunto das acepções de DE?

Vejamos como Moriyama responde a essa questão:

Realmente, na análise de Langacker, o caso instrumental, como elemento incluído na cadeia de ações, é um dos casos do primeiro plano. Entretanto, o instrumento marcado com o caso instrumental é o participante passivo do domínio de origem. Ainda, dentre os participantes da cadeia de ações, os que recebem a atenção do sujeito da cognição são o Trajector (agente, sujeito) e o Landmark (paciente, objeto); o instrumento, situado no estreito espaço entre o agente e o paciente, mesmo fazendo parte da cadeia de ações, está em um local difícil de ser focalizado. Além disso, o elemento que faz o papel de instrumento, quase sempre, ora é parte do corpo do agente, ora é um intermediário pequeno e temporário. No caso do inglês e de outras línguas, mesmo assim ele é passível de focalização, e como resultado pode ser interpretado como participante da cadeia e colocado na posição de sujeito. No caso do japonês, porém, frases como "o martelo quebrou o copo", em que o instrumento torna-se sujeito, não são freqüentes. Isto é, devido a sua pouca possibilidade de focalização, é mais apropriado considerar o caso instrumental do japonês como parte do segundo plano [o fundo]. Desse modo, diferentemente da visão de Langacker, podemos considerar o instrumento como um elemento auxiliar na composição do suporte da cadeia de ações, da mesma forma que local, horário, causa, material etc. (MORIYAMA 2004 p. 32)

Em poucas palavras, o que Moriyama quer dizer é que, em japonês, o instrumento, do mesmo modo que os outros elementos (local etc.) que podem compor o fundo e ser marcados com DE, dificilmente pode ser destacado pelo sujeito da cognição a ponto de, por exemplo, ser interpretado como agente (compare-se o instrumento com o objeto da ação: este pode passar à condição de sujeito da frase, através da construção da voz passiva).

Existe ainda um argumento complementar para considerarmos DE como marcador do fundo mais do que como participante da cadeia de ações. Trata-se do fato de que o elemento marcado com DE não interfere no resultado final da ação do agente sobre o paciente. Consideremos os exemplos 20 a 24 abaixo: 
20. Tarôwa daidokoro de jûsu wo tsukutta.

Taro TOP cozinha DE suco ACS fazer-perf.

Taro fez um suco na cozinha.

21. Tarôwa san-pun de jûsu wo tsukutta.

Taro TOP três minutos DE suco ACS fazer-perf.

Taro fez um suco em três minutos.

22. Tarôwa mikisâde jûsu wo tsukutta.

Taro TOP liquidificador DE suco ACS fazer-perf.

Taro fez um suco no liquidificador.

23. Tarôwa banana de jûsu wo tsukutta.

Taro TOP banana DE suco ACS fazer-perf.

Taro fez um suco com bananas.

24. Tarôwa gakkôno shukudaide jûsuwo tsukutta.

Taro TOP escola GEN tarefa DE suco ACS fazer-perf.

Taro fez um suco como tarefa da escola.

Qualquer que seja o elemento marcado com DE, a ação de "Taro" sobre "suco" é a mesma, isto é, o caso DE é secundário com relação ao evento.

Vejamos agora, dentre os elementos que podem compor o fundo, qual poderia ser o prototípico, e como outros tipos de elementos estariam relacionados com o protótipo.

O elemento físico, que dá suporte material a qualquer tipo de evento que aconteça, é o local. Podemos considerar, em coro com a trajetória diacrônica de DE, que esta seja sua acepção prototípica.

Além do local físico que sustenta o evento observado, o sujeito da cognição pode focalizar, no segundo plano do cenário, outros elementos, através do exercício do raciocínio ou da interpretação. No cenário recortado para a expressão lingüística, esses outros elementos estão para o local como, no teatro, objetos de cena e figurantes estão para o palco. Seguindo uma escala do concreto para o abstrato, e do mais independente para o mais dependente da interpretação do sujeito da cognição, temos os elementos instrumento, causa e situação/aspecto. A colocação do foco em um ou outro desses elementos está a cargo do 
usuário da língua; por isso, esse processo é chamado de subjetivização do fundo (MORIYAMA, 2005, p. 47).

Cada um desses domínios cognitivos, local, instrumento, causa e situação/aspecto, contém elementos mais concretos e mais abstratos.

No domínio local, entram, além dos locais fisicos (exemplo 1), os locais abstratos (exemplo 2).

1. sono kaigiwa amerika de hirakareru. essa reunião TOP Estados Unidos DE realizar-se-pasv. Essa reunião será realizada nos Estados Unidos.

2. kare no keikaku de wa kono mondai wa atsukawarete inai. ele GEN plano DE CTR este problema TOP lidar-pasv.-cont.-neg. No plano dele, este problema não é contemplado.

Relacionadas a local, temos ainda as acepções de área demarcada (exemplo 3) e limite (exemplo 4). A primeira é motivada diretamente pela noção de local, com a diferença de que o sujeito da cognição destaca o contorno da área. A segunda é o resultado de uma ênfase no contorno associada à desfocagem da área interna.

3. eberesuto wa sekai de ichiban takai yama desu.

Everest TOP mundo DE o mais alto montanha-afirm.

O Everest é a montanha mais alta do mundo.

4. sanjû-nin de shimekirimasu.

trinta pessoas DE fecha

Fecharemos com trinta pessoas.

DE ainda pode marcar um elemento que, apesar de ser em princípio um local, poderia em alguns casos ser interpretado como o agente do movimento (exemplo 5). Isso é o resultado da colocação consciente pelo sujeito da cognição do "local-agente" no fundo do cenário (MORIYAMA, 2005, p. 47). 
5. sono jiken wa keisatsu de sôsa-shite imasu.

Esse incidente TOP polícia DE investigar-cont.

Esse incidente está sendo investigado pela polícia.

Finalmente, de acordo com a metáfora convencional HORÁRIOS SÃO LOCAIS (LAKOFF e JOHNSON, 1995), um horário ou uma data pode ser tomado como fundo (exemplo 6). E do mesmo modo que o sujeito da cognição pode enfatizar os contornos de um local, também pode destacar os limites de tempo, estabelecendo como fundo um período (exemplo 7) ou uma data/horário limite (exemplo 8).

6. shokuji no ato de, benkyô wo shimasu. refeição GEN depois DE estudo ACS fazer Depois das refeições, eu estudo.

7. seichôno kateide ichijitekini arawareru genshôdesu. desenvolvto GEN processo DE temporariamtemanifestar-se fenômeno-afirm. É um fenômeno que se manifesta temporariamente no processo de desenvolvimento.

8. natsuyasumi wa ashita de owaridesu. férias de verão TOP amanhã DE fim-afirm.

As férias de verão, amanhã terminam.

O domínio instrumento, engloba, além dos instrumentos concretos (exemplo 9), os meios, os materiais e os elementos estruturais. O meio (exemplo 10) é um instrumento mais abstrato. Instrumento e meio motivam as acepções de material (concreto) e elemento estrutural (abstrato) por meio da focalização de elementos internos às coisas observadas (exemplos 11 e 12).

9. nihonjin wa hashide mono wo taberu. japonês TOP hashi DE coisa ACS comer Os japoneses comem coisas com hashi.

10. karewa kôkûbin de tegamiwo okutta. ele TOP via aérea DE carta ACS enviar-perf. Ele enviou a carta por via aérea.
11. kono tsukue wa
ki de dekite imasu. esta escrivaninha TOP madeira DE ser feita-cont. Esta escrivaninha é feita de madeira. 
12. nihon bunkano tokuchô to iu daimokude ronbunwo kakimashita. cultura japonesa GENcaracterística CIT tema DE tese ACS escrever-perf Escreveu uma tese com o tema "características da cultura japonesa".

Dentro do domínio causa, temos um contínuo de causas mais objetivas até causas mais subjetivas. Nessa ordem, temos as acepções de causa propriamente dita, razão, fundamento e motivação/objetivo (exemplos 13 a 16).

13. byôki de gakkôwo yasumu. doença DE escola ACS faltar

Faltar à escola por doença.

14. sô iu ten de omoshiroito omou. esse ponto DE interessante CIT achar Acho interessante por causa desse ponto.

15. shiken no kekkade handan-suru. prova GEN resultado DE decidir Decidiremos com base no resultado da prova.

16. shucchôde Ôsakae itta. viagem de negócios DE Osaka ALT ir-perf. Foi a Osaka em viagem de negócios.

Finalmente, o domínio situação/aspecto é o mais subjetivo de todos. Esse domínio é resultado do filtro interpretativo do sujeito da cognição sobre o agente, o paciente ou o movimento/evento observados (exemplos 17 a 19).

17. yûgohan wa jibun de tsukutte tabemasu. jantar TOP sozinho DE fazer ADT comer O jantar, eu faço e como sozinho.

18. chiisana oto de ongaku wo kikimashita. volume baixo DE música ACS ouvir-perf.

Ouvi a música com volume baixo.

19. mô-supiido de hashitte imasu. velocidade feroz DE correr-cont. Corre a uma velocidade feroz.

As ligações que existem entre as acepções da posposição de caso DE podem ser traduzidas graficamente como na Figura 3. 


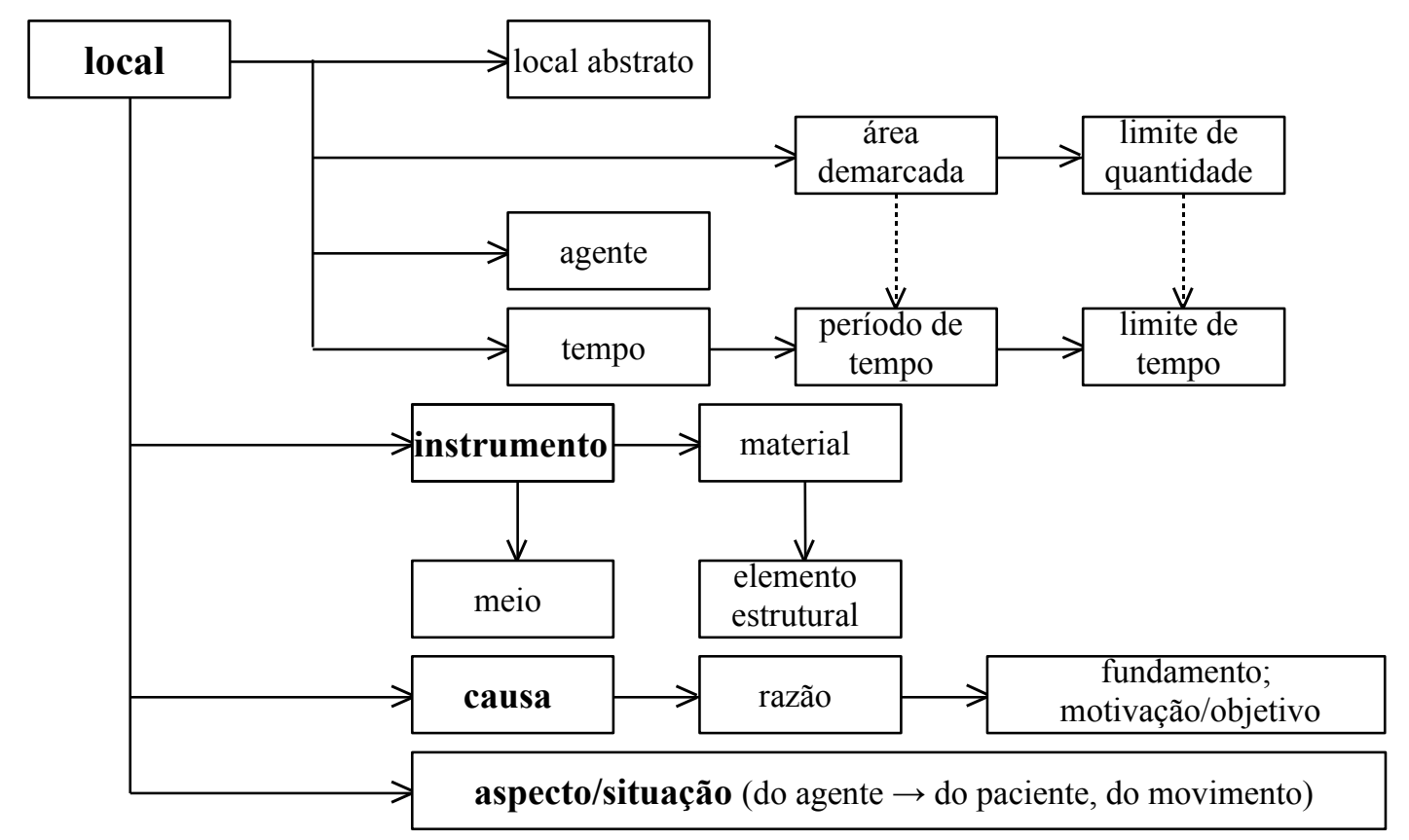

FIGURA 3: estrutura radial da categoria formada pela posposição de caso DE (MORIYAMA 2005, p. 47)

\subsection{Mapeamento de preposições do português em DE}

De modo análogo ao que fizemos com a posposição de caso NI, neste item procuraremos determinar quais serão as preposições do português que podem ser mapeadas em DE para cada uma de suas acepções.

\subsubsection{Acepções do domínio local}

Logo nos seus primeiros contatos com a posposição de caso DE, o aprendiz lusófono tem de se deparar com uma "nova realidade": em japonês, existem "dois locativos", um para localização de entes - NI, e outro para localização de eventos - DE. Em português, essa distinção não existe: a localização tanto de entes como de eventos é marcada com a preposição $\mathrm{em}$.

Como resultado, o aprendiz lusófono de japonês apresenta uma forte tendência a usar NI para marcar local em qualquer contexto, indiscriminadamente. A aquisição do uso de DE como marcador de "palco para uma atividade" requer esforço consciente do aprendiz. 
Em suma, não há uma preposição em português que marque especificamente localização de evento; logo, não há lugar para um mapeamento. Essa afirmação vale tanto para a acepção prototípica, a de local físico, como para as extensões desta.

Contudo, cremos que ainda seja válido observar quais preposições do português seriam utilizadas no lugar de DE nas traduções das acepções do domínio local, com vistas a fornecer subsídios para a organização da apresentação de DE para o aprendiz lusófono. Em termos práticos: não falaremos de mapeamento de preposições em DE para as acepções do domínio local, mas comentaremos aqui as possibilidades de tradução da posposição em cada uso.

\subsubsection{Local}

1. sono kaigiwa amerika de hirakareru. essa reunião TOP Estados Unidos DE realizar-pasv. Essa reunião será realizada nos Estados Unidos.

Para marcar localização, tanto de um ente como de um evento, o português utiliza a preposição em.

Nos cursos básicos em geral, a posposição NI, em sua acepção de marcador de localização, é apresentada antes de DE, pois a tarefa comunicacional de "informar existência ou localização" é considerada mais primária que a de "descrever um evento". O aprendiz chega ao seu primeiro contato com DE sem a noção dessa diferença de tarefas, e já acostumado a mapear em em NI. Faz-se necessário, pois, um esforço consciente para se assimilar essa distinção.

\subsubsection{Local abstrato}
2. kare no keikakudewa kono mondai wa atsukawarete inai. ele GEN plano DE CTR este problema TOP lidar-pasv.-cont.-neg. No plano dele, este problema não é contemplado.


Para o uso de DE como marcador de local abstrato, cabem as mesmas considerações relativas a local concreto.

\subsubsection{3. Área demarcada}

3. eberesuto wa sekai de ichiban takai yama desu.

Everest TOP mundo DE o mais alto montanha-afirm.

?o Everest é a montanha mais alta no mundo.

O Everest é a montanha mais alta do mundo.

A área demarcada de que trata esta acepção é uma referência para avaliações relativas como "a montanha mais alta do mundo", "a cobra mais rápida do deserto" etc.

Para marcar esse referencial, em português, de é usado com muito mais freqüência que em. Mais ainda, em se tratando de seres animados, não encontramos ocorrências de $\mathrm{em}$, mas apenas de $d e$ (o homem mais alto do mundo / *o homem mais alto no mundo).

\subsubsection{Limite}

4. a) sanjû-nin de shimekirimasu. trinta pessoas DE fecha Fecharemos com trinta pessoas (quando houver trinta pessoas).

b) marason no jûsan-kiro de yameta. maratona GEN treze quilômetros DE desistir-perf.

?desistiu com treze quilômetros da maratona.

Desistiu aos treze quilômetros da maratona.

c) mizu wa hyaku-do de suijôki ni naru. água TOP cem graus DE vapor DAT torna-se ?a água torna-se vapor com cem graus A água torna-se vapor aos cem graus.

Nesta extensão, já mais afastada da acepção de local, já não é possível traduzir DE como em.

O limite a que se refere esta acepção é de quantidade. Em japonês, não importa a medida considerada para o limite; este sempre pode ser marcado com DE. Já em português, se 
a quantidade referida for de uma substância concreta (exemplo 4a), prefere-se com; se se tratar de gradações mais abstratas (exemplos $4 \mathrm{~b}$ e 4c), o usuário preferirá $a$.

\subsubsection{Agente de movimento}

5. sono jiken wa keisatsu de sôsa-shite imasu.

Esse incidente TOP polícia DE investigar-cont.

?esse incidente está sendo investigado na polícia.

Esse incidente está sendo investigado pela polícia.

Conforme referimos anteriormente, este uso de DE coloca na condição de fundo um local que de outro modo estaria na posição de sujeito (com GA (NOM) marcando "polícia" no lugar de DE, o que pode ocorrer normalmente). Esse uso de DE, "cobrindo" a posposição GA para diminuir o destaque do sujeito na cadeia de ações, é análogo ao de WA, que tem a função inversa, de realçar o sujeito ou outro participante para um efeito de contraste. Trata-se portanto de um uso discursivo, e não sintático. O português não dispõe de "preposições discursivas".

Especificamente com relação ao exemplo 5, no qual o sujeito pode ser interpretado como um local, cabe uma observação interessante. Dentro das metáforas convencionais do português, elementos do domínio das instituições (polícia, governo, universidades, agremiações etc.) tendem a ser considerados metaforicamente como pessoas. Tomando emprestada a convenção de Lakoff e Johnson (1995), poderíamos dizer que, em português, em geral INSTITUIÇÕES SÃO PESSOAS. Em japonês, a tendência é outra: é mais freqüente a aplicação da metáfora InSTITUIÇÕES SÃO LUGARES. Um exemplo mais claro dessas tendências se mostra na comparação dos interrogativos utilizados para se perguntar sobre países: para questionar, por exemplo, quais países exercem determinada atividade, o brasileiro usará o pronome quem ("quem faz isso?"); já o japonês usará um interrogativo correspondente a "onde" ("sore wa doko ga yatte iru no?"). 
Daí ser mais natural em português a tradução "investigado pela polícia", com uma preposição que marca agente da passiva, do que "investigado na polícia", com um marcador de local.

De todo modo, porém, não há um recurso em português, materializado em uma preposição, que "empurre" o agente do movimento para o fundo do cenário.

\subsubsection{Tempo}

6. shokuji no ato de, benkyô wo shimasu. refeição GEN depois DE estudo ACS fazer Depois das refeições, [eu] estudo.

Esta acepção refere-se a um tempo sem um limite final definido, dentro do qual ocorre um evento.

O uso de DE aqui também é discursivo; em termos sintáticos, o constituinte "depois da refeição" no exemplo 6 dispensaria qualquer posposição. A tradução em português também dispensa preposição; ainda, como já observamos, o português não dispõe de preposição equivalente a DE em seu uso discursivo.

\subsubsection{Período de tempo}

7. seichôno kateide ichijitekini arawareru genshôdesu. desenvolvto GEN processo DE tempormte manifestar-se fenômeno-afirm. É um fenômeno que se manifesta temporariamente no processo de desenvolvimento.

Esta acepção pode ser entendida como extensão metafórica da de área demarcada, sendo, nesse sentido, mais próxima do protótipo de local. Daí ser viável, neste uso, a tradução de DE como em. 


\subsubsection{Limite de tempo}

8. natsuyasumi wa ashita de owari desu. férias de verão TOP amanhã DE fim-afirm.

As férias de verão, terminam amanhã.

Em termos semânticos, esta acepção pode ser considerada extensão de limite (de quantidade) (exemplo 4); sintaticamente, porém, uma vez que DE aqui é dispensável como marcador de caso, e portanto está em uso discursivo, trata-se de mais uma aplicação do morfema que não permite tradução.

\subsubsection{Acepções do domínio instrumento}

Em português, de acordo com a metáfora quase universal apontada por Lakoff e Johnson (1995, p. 76): INSTRUMENTOS SÃO COMPANHEIROS, o instrumento é marcado pela preposição com. Vejamos se a correspondência entre com e DE se mantém para as extensões de instrumento.

\subsubsection{Instrumento}

9. nihonjin wa hashide mono wo taberu. japonês TOP hashi DE coisa ACS comer

Os japoneses comem coisas com hashi.

Conforme a argumentação de Moriyama exposta no item 3.1 sobre a estrutura semântica de DE, o instrumento em japonês é considerado mais como parte do fundo do que como parte da cadeia de ações. Invertendo a perspectiva, podemos afirmar que, apesar do seu pouco destaque, o instrumento ainda é um elemento da cadeia. Desse modo, podemos admitir que a acepção de DE como marcador de instrumento permite o mapeamento de com. Quando se trata de um instrumento concreto, a nuance de "elemento secundário" do japonês pode ser desprezada na associação entre com e DE. 


\subsubsection{Meio}

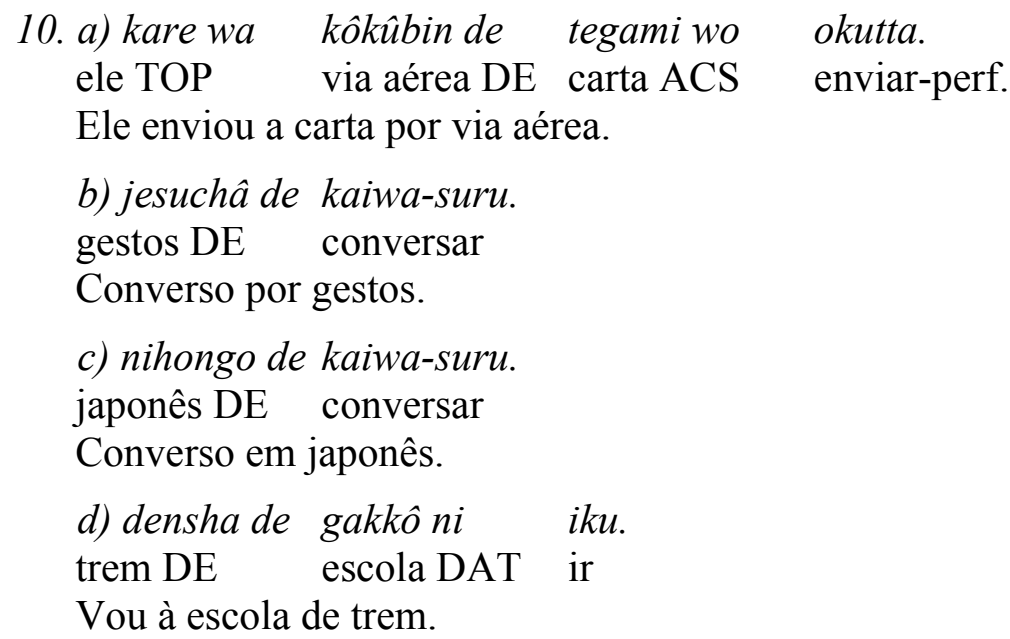

A noção de meio resulta da projeção de instrumento em um nível mais abstrato.

Aqui já não é mais possível mapear com em DE; diferentemente de instrumento, um meio não pode ser considerado "companheiro", dada sua falta de concretude.

Em português, não há uma categoria uniforme que, sob o rótulo de meio, determine o uso de uma única preposição. O "meio" pode ser um CANAL ${ }^{15}$, como nos exemplos 10a e 10b, determinando a escolha de por; pode ser uma linguagem verbal (exemplo 10c), que exigirá em, ou pode ser um veículo, pedindo $d e^{16}$.

Em suma, o que a língua japonesa reúne sob DE como marcador de meio, o português separa em categorias menores. Para efeito de mapeamento, porém, podemos aceitar a associação de por, em ou de em DE.

\subsubsection{Material}
11. kono tsukue wa
ki de
dekite imasu.
esta escrivaninha TOP
madeira DE ser feita-cont.
Esta escrivaninha é feita de madeira.

\footnotetext{
15 Um dos esquemas de imagem convencionais da linguagem humana segundo Lakoff e Johnson (1995).

16 Quando o meio de transporte pertence ao sujeito, é tratado como instrumento-companheiro, regendo com (ex.: "fui ao Sauípe com meu helicóptero").
} 
A noção de material se afasta pouco da de instrumento. Trata-se de um conceito que exige um mínimo de raciocínio do sujeito da cognição, a mais do que o necessário para se captar um instrumento, mas é tão concreto quanto este.

Seguindo a tendência das acepções de nível mais concreto, a noção de material facilita o mapeamento de uma preposição do português em $\mathrm{DE}$, que, neste caso, seria de. Com também é usado em português para marcar material, mas é preferido quando se trata de destacar um ou outro elemento estrutural ou ingrediente da composição do objeto observado, como veremos no item a seguir.

\subsubsection{Elemento estrutural}

12. a) nihon bunka no tokuchô to iu daimokude ronbunwo kakimashita. cultura japonesa GENcaracterística CIT tema DE tese ACS escrever-perf Escreveu uma tese com o tema "características da cultura japonesa".

b) kurozatô de kêki wo tsukutte imasu. acúcar mascavo DE bolo ACS fazer-cont.

Estou fazendo um bolo com açúcar mascavo.

Estamos tratando agora de uma projeção do conceito de material em um nível mais abstrato. O marcador DE agora aponta para um dos elementos que compõem a estrutura (ou um dos ingredientes do material, como no exemplo $12 \mathrm{~b}$ ) do objeto observado.

O português marca o elemento estrutural (ingrediente isolado) com a preposição com $^{17}$, que pode, assim, ser mapeada em DE nesta acepção.

\subsubsection{Acepções do domínio causa}

\subsubsection{Causa}

13. a) byôki de gakkôwo yasumu. doença DE escola ACS faltar Faltar à escola por doença.

17 Em exemplos como "estou fazendo um bolo de nozes", obviamente as nozes não são o único ingrediente do bolo; entretanto, trata-se de uma aplicação de metonímia, em que "nozes" distingue um tipo dentre vários possíveis, e exprime, nesse sentido, a "essência" do bolo. 
b) kan'en de shinda.

hepatite DE morrer-perf.

Morreu de hepatite.

c) taifû de kiga taoreta.

tufão DE árvore NOM cair-perf.

A árvore caiu com o tufão.

Em português, para expressar causa concreta, é freqüente o uso de locuções como por motivo de, por causa de ou devido a. Para fazê-lo com apenas uma preposição, usa-se de, por ou com.

Essas preposições não são livremente intercambiáveis entre si nesta acepção, e sua distribuição obedece a um critério complexo, que não cabe esmiuçar neste trabalho ${ }^{18}$. Para efeito de mapeamento, porém, podemos admitir que qualquer uma das três pode ser mapeada em DE.

\subsubsection{Razão}

14. sô iu ten de omoshiroi to omou.

esse ponto DE interessante CIT achar

?acho interessante por esse ponto

Acho interessante por causa desse ponto.

Mais uma vez, afastamo-nos apenas mais um passo do centro da estrutura radial de acepções e já encontramos diferenças notáveis entre as duas línguas. O simples uso de por não deverá ser aceito pacificamente como marcador de razão por qualquer usuário nativo do português. Resta mapear em DE as locuções preposicionadas citadas no item anterior. Pode haver nuances que determinem a escolha de uma ou outra locução; para efeito de mapeamento, porém, essas diferenças podem ser desprezadas.

18 Um estudo pormenorizado sobre a distribuição das preposições de e com com sentido de causa encontra-se em Catarino e Pinto (2004). 


\subsubsection{Fundamento}

15. shiken no kekkade handan-suru. prova GEN resultado DE decidir ?decidiremos pelo /com o resultado da prova.

Decidiremos com base no / de acordo com o resultado da prova.

Novamente, traduções do japonês mais naturais em português pedem o uso de locuções. Conforme se eleva o grau de abstração da acepção observada, a correspondência entre uma preposição simples e DE se torna mais difícil.

\subsubsection{Motivação/objetivo}

\begin{tabular}{|c|c|c|c|}
\hline $\begin{array}{l}\text { 16. a) shucchô de } \\
\text { viagem de negócios } \mathrm{DE} \\
\text { Foi a Osaka em viagem de } \mathrm{r} \\
\text { (Foi a Osaka a trabalho) }\end{array}$ & $\begin{array}{l}\text { Osaka e } \\
\text { Osaka ALT } \\
\text { egócios. }\end{array}$ & $\begin{array}{l}\text { itta. } \\
\text { ir -perf. }\end{array}$ & \\
\hline $\begin{array}{l}\text { b) ryûgaku de } \\
\text { viagem de estudos DE } \\
\text { Vim ao Brasil em viagem d } \\
\text { (*vim ao Brasil a estudo) }\end{array}$ & $\begin{array}{l}\text { Burajiru e } \\
\text { Brasil ALT } \\
\text { estudos. }\end{array}$ & $\begin{array}{l}\text { kita. } \\
\text { vir-perf. }\end{array}$ & \\
\hline $\begin{array}{ll}\text { c) Tarô wa } & \text { gakkô no } \\
\text { Taro TOP } & \text { escola GEN } \\
\text { Taro fez um suco como tare }\end{array}$ & $\begin{array}{l}\text { shukudai de } \\
\text { tarefa DE } \\
\text { fa da escola. }\end{array}$ & $\begin{array}{l}\text { jûsu wo } \\
\text { suco ACS }\end{array}$ & $\begin{array}{l}\text { tsukutta. } \\
\text { fazer-perf. }\end{array}$ \\
\hline $\begin{array}{l}\text { d) asobi de Tôkyôe } \\
\text { diversão DE Tokyo ALT } \\
\text { Vou a Tokyo por diversão. } \\
\text { (Vou a Tokyo para me divel }\end{array}$ & $\begin{array}{l}i k u . \\
\text { ir. } \\
\text { tir.) }\end{array}$ & & \\
\hline
\end{tabular}

Na ponta do galho dentro da estrutura semântica de DE, esta acepção é de natureza altamente subjetiva. Marcando o complemento com DE, o emissor da mensagem especifica um contexto para a ação descrita, mas tira o foco do receptor sobre a questão de se se trata de uma causa ou de um objetivo.

Em português, os complementos "em viagem de negócios" e "em viagem de estudo" também deixam desfocada a relação causal, bem como "a serviço", "a trabalho" etc. São, porém, expressões cristalizadas e de uso restrito a certos contextos. Não é possível associar a 
uma preposição específica a propriedade de "empurrar para o fundo do cenário" a causa ou o objetivo de uma ação. Em outras palavras, esse recurso não é inexistente no português, mas também não é possível mapear uma preposição em DE nesta acepção.

\subsubsection{Acepções do domínio situação/aspecto}

\subsubsection{Situação/aspecto de agente de movimento}

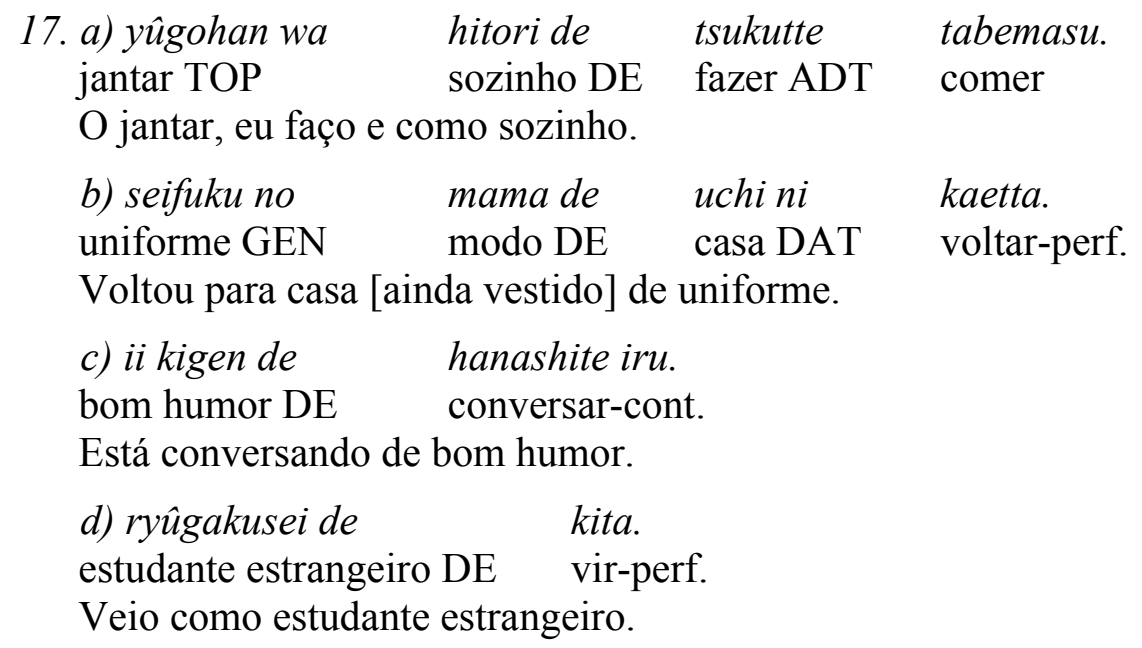

Este uso de DE é normalmente usado para expressar quantidade de pessoas, vestuário, estado de espírito e posição social. Para as três primeiras, o correspondente a DE nesta acepção é a preposição de, e para a última, é o advérbio como.

A definição de advérbio implica em que o vocábulo, no caso, como, modifique o verbo, e não o sujeito. Não podemos negar, no entanto, que como modifique o sujeito, e não a ação, no exemplo $17 \mathrm{~d}$.

Em suma, podem ser mapeados de e como em DE como marcador de aspecto ou situação do sujeito. 


\subsubsection{Situação/aspecto de paciente de movimento}

18. chiisana oto de ongaku wo kikimashita. volume baixo DE música ACS ouvir-perf.

Ouvi a música a / com / em um volume baixo.

Em português, o aspecto do paciente de um movimento é marcado pelo uso de com, em ou $a$, preposições que podem ser mapeadas em DE indiscriminadamente, apesar de poderem variar em nuances no português.

\subsubsection{Situação/aspecto de movimento ou evento}

19. a) mô-supiido de hashitte imasu. velocidade feroz DE correr-cont.

Corre ?em / ?com / a uma velocidade feroz.

b) *jôhinsa de $\quad$ ugoku.
elegância DE
Move-se com elegância.

Este é um uso restrito de DE. No levantamento de exemplos em corpora, não encontramos outros "aspectos de movimento" associados a DE, além do que aparece em 19a. Por exemplo, chikara (força), ikioi (impulso), hageshisa (intensidade) etc., não são associadas a DE como aspectos (com força, com impulso, com intensidade), mas apenas como causa (com a força do vento, com o impulso do momento, com a intensidade da vibração etc.).

O português é muito mais flexível nesse sentido: são naturais frases como corre com graça, dança com elegância etc. Isso significa que é possivel traduzir DE para o português como a, em ou com, mas não mapear essas preposições em DE.

\subsubsection{Resumo: mapeamentos de preposições em DE}

As tabelas 1, 2, 3 e 4 resumem os mapeamentos possíveis de preposições do português em DE. Sinais de "x" indicam que a construção não tem equivalente direto no português, e o ponto de interrogação indica que não é possível um mapeamento consistente (o que ocorre 
apenas na tabela 3$)$.

É importante ressaltar novamente que incluímos associações de preposições com DE nas acepções do domínio local apenas como dado complementar, pois o português não distingue o local de evento do local de ente.

O exame das tabelas revela que, quanto mais nos afastamos dos usos prototípicos de DE, o mapeamento tende a se tornar complexo (mais preposições podem ser associadas a DE) ou impossível.

Tabela 1: preposições que podem ser associadas a DE nas acepções do domínio local

\begin{tabular}{|c|c|c|c|}
\hline local & local abstrato & área & limite \\
\hline \multicolumn{2}{|c|}{$\mathrm{em}$} & $\mathrm{de} / \mathrm{em}$ & $\mathrm{com} / \mathrm{a}$ \\
\hline agente & & & \\
\hline $\mathrm{x}$ & período & limite de tempo & \\
\hline tempo & $\mathrm{em}$ & $\mathrm{x}$ & \\
\hline $\mathrm{x}$ & & & \\
\hline
\end{tabular}

Tabela 2: preposições que podem ser mapeadas em DE nas acepções do domínio instrumento

\begin{tabular}{|c|c|}
\hline instrumento & meio \\
\hline com & $\mathrm{com} / \mathrm{em}^{19} / \mathrm{de}^{20}$ \\
\hline material & elemento estrutural \\
\hline $\mathrm{de}$ & com \\
\hline
\end{tabular}

Tabela 3: preposições que podem ser mapeadas em DE nas acepções do domínio causa

\begin{tabular}{|c|c|c|c|}
\hline causa & razão & fundamento & motivação/objetivo \\
\hline $\mathrm{de} /$ por/com & locuções preposicionadas & $\mathrm{x}$ \\
\hline
\end{tabular}

Tabela 4: preposições que podem ser mapeadas em DE nas acepções do domínio aspecto/situação

\begin{tabular}{|c|c|c|}
\hline aspecto do agente & aspecto do paciente & $\begin{array}{c}\text { aspecto do } \\
\text { movimento }\end{array}$ \\
\hline $\mathrm{de} / \mathrm{como}$ & $\mathrm{com} / \mathrm{em} / \mathrm{a}$ & $?$ \\
\hline
\end{tabular}

\footnotetext{
19 Exclusivo para língua

20 Exclusivo para meio de transporte
} 


\title{
4. As acepções de WO e suas expressões em português
}

Das três posposições analisadas neste trabalho, WO é a que tem a estrutura semântica mais simples.

Em sua acepção prototípica, WO marca objeto direto, correspondendo assim ao caso acusativo. Entretanto, essa mesma posposição também pode marcar local, condições e tempo, como mostram os exemplos abaixo.

\author{
objeto direto \\ 1. jûsu wo поти. \\ suco WO beber \\ Bebo suco.
}

\section{local-ponto de partida}

2. hachi-jini iewo deru. oito horas DAT casa WO sair Saio de casa às oito horas.

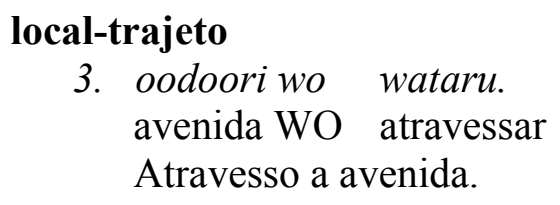

3. oodoori wo wataru. avenida WO atravessar Atravesso a avenida.

\section{condições}

4. Tarôga ame no nakawo iku.

Taro NOM chuva GEN dentro WO ir

Taro vai dentro (debaixo) de chuva.

\section{tempo}
5. natsuyasumi wo Okinawa de sugosu.
férias de verão WO Okinawa L-INS passar
Passo as férias de verão em Okinawa.

Conforme aponta Moriyama (2005, p. 51), os usos representados pelos exemplos 2 a 5

[...] suscitam questões quanto à classificação [de WO] como marcador de objeto direto, tanto do ponto de vista da sintaxe como da semântica. As questões sintáticas são: se os verbos [nesses exemplos] aceitam objetos ou não; e se aceitam ou não a conversão para a voz passiva. As questões semânticas são: o grau de transitividade, isto é, se a ação expressa no verbo é dirigida a um objeto ou não; e se for, em que medida exerce influência sobre o objeto, na percepção do falante. Observados à luz da sintaxe, os verbos dos exemplos [2 a 5] não possuem objeto, nem podem ser passivizados; da semântica, é difícil admitir que haja transitividade entre os verbos e os locais ou tempo marcados com WO. Entretanto, é ao mesmo tempo absurdo 
considerar essas distinções de uso como um caso de homonímia.

O caso acusativo do japonês, marcado com WO, e o do português, ao qual não se associa qualquer preposição (daqui em diante, referiremo-nos como "marcador zero"), guardam semelhanças e diferenças de uso, conforme os contextos semânticos em que ocorrem. Neste capítulo procuraremos determinar até onde vão as semelhanças com o português, com base na estrutura semântica de WO proposta por Moriyama (2005).

\subsection{A estrutura semântica de WO}

Relembrando o que observamos na parte introdutória desta dissertação, o sujeito e o objeto prototípicos são dois participantes de uma dinâmica de forças. A transitividade prototípica é a relação de transmissão direta de energia de um agente para um paciente. $\mathrm{O}$ caso nominativo prototípico é aquele que expressa o agente em uma relação transitiva e o caso acusativo prototípico é o que expressa o paciente em uma relação transitiva. Ações podem ser mais concretas ou mais abstratas (beber / entender), bem como os objetos (suco / questões). Ao aumento do grau de abstração da ação e dos objetos verbalizados, associa-se o afastamento com relação à transitividade prototípica, evidenciando-se a aplicação de um esquema abstrato pelo usuário da língua. $\mathrm{O}$ esquema é o que une o protótipo e suas várias extensões, menos concretas e mais abstratas, em uma estrutura radial. Vejamos abaixo os protótipos e esquemas de transitividade, sujeito e objeto.

\section{Transitividade}

- Prototípica: transmissão direta de energia de um agente a um paciente

- Esquemática: relação assimétrica entre dois participantes

\section{$\underline{\text { Sujeito }}$}


- Prototípico: o agente como nó inicial da cadeia de ações

- Esquemático: o participante com o maior destaque na relação assimétrica (Trajector).

\section{Objeto}

- Prototípico: o paciente como nó final da cadeia de ações.

- Esquemático: o participante com segundo maior destaque na relação assimétrica (LM).

Passemos agora a uma descrição mais detalhada do sentido prototípico de $\mathrm{WO}$, bem como de suas extensões.

\subsubsection{O protótipo e as extensões de WO}

\subsubsection{1. $A$ acepção prototípica: objeto direto}

No nó final da cadeia de ações, o sujeito da cognição pode colocar tanto um participante marcado com WO, como um marcado com NI.

Para optar entre a marcação do participante com WO ou com NI, o sujeito da cognição estabelece em torno do agente (participante marcado com GA) uma área de influência direta de força sobre o objeto. Se o objeto da ação for percebido como estando dentro dessa área, é marcado com WO. Se estiver fora, é marcado com NI, pois, como notamos no Capítulo 1, o participante NI é caracterizado pela independência com relação ao GA (Figura 2).

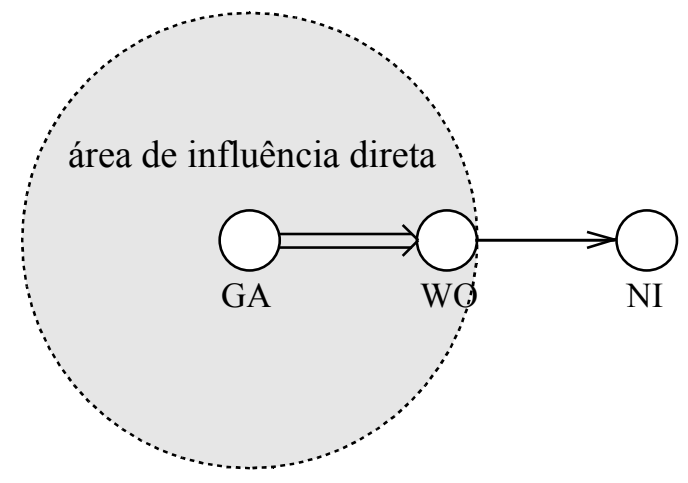

Figura 2: Dinâmica de forças entre GA e WO e entre GA e NI 
Essas colocações podem ser ilustradas com os seguintes exemplos:

6. a) kodomo wo hatarakaseru.

criança WO fazer trabalhar

Faço a criança trabalhar.

b) kodomo ni hatarakaseru. criança NI fazer trabalhar

Faço a criança trabalhar.

7. a) yama ni noboru.

montanha NI subir

Subo na montanha.

$\begin{array}{ll}\text { b) yama wo } & \text { noboru. } \\ \text { montanha WO } & \text { subir } \\ \text { Subo a montanha. } & \end{array}$

No exemplo 6a, a criança é expressa como um objeto dentro da área de influência da força do sujeito, o que não acontece em $6 \mathrm{~b}$. Na prática, isso representa a diferença entre, por exemplo, obrigar diretamente a criança a trabalhar (mandando, ameaçando etc.) ou levar a criança a trabalhar por motivos independentes da vontade do sujeito (por exemplo, o sujeito pode ser pai da criança e estar impossibilitado de trabalhar).

A comparação entre $7 \mathrm{a}$ e $7 \mathrm{~b}$, recorrente em livros didáticos, também pode ser expressa em termos da área de influência da força: em 7a, a montanha é colocada fora do alcance imediato do sujeito, o que equivale a dizer que a montanha não é considerada escalada antes que se chegue a seu topo. Em 7b, a montanha é colocada sob os pés do escalador, focalizando-se o processo da escalada.

Como conseqüência dessas propriedades, surgem certas tendências na distribuição de WO e NI: objetos de caráter mais dependente com relação à ação verbalizada tendem a ser marcados com WO, e aqueles mais independentes tendem a receber NI; mais ainda, se o objeto for um ser inanimado, tende a receber WO; se for uma pessoa, tende a ser marcado com NI. Isso pode ser observado nos exemplos $8 \mathrm{a}, 8 \mathrm{~b}$ e $8 \mathrm{c}$. 
8. a) eigo wo oshieru. inglês WO ensinar Ensino inglês.

b) daigakusei wo oshieru. universitários WO ensinar Ensino universitários.

c) gakusei ni eigo wo oshieru. universitários NI inglês WO ensinar Ensino inglês para universitários.

O fato de em 8c "universitários" ser marcado com NI e "inglês" ser marcado com WO se deve ao fato de "inglês" receber a influência direta de "ensinar" e ter um caráter meramente passivo; em comparação, "estudantes" é percebido pelo sujeito da cognição como tendo um caráter ativo, e assim é colocado fora da influência direta da força do agente. Em termos mais simples, o sujeito da cognição percebe uma hierarquia entre "inglês" e "estudantes" para determinar qual elemento será marcado com WO ou com NI. As traduções dos exemplos mostram que existe analogia entre o português e o japonês nesse ponto.

\subsubsection{Local}

De acordo com o sentido esquemático de WO, o local deve "estar ligado ao agente (GA), que é ponto de partida da cadeia de ações, e estar colocado dentro da área de influência de sua força (no ponto final da cadeia)" (MORIYAMA, 2005, p. 55). Na cadeia de ações prototípica, o que está ligado desse modo ao agente é um ser inanimado (objeto), e a ação em questão é uma transferência de energia. Em japonês, ocorre uma projeção metafórica de coisa em local, e de transferência de energia em deslocamento. Com isso, o esquema de imagem DINÂMICA DE FORÇAS dá lugar ao esquema de TRAJETÓRIA. 


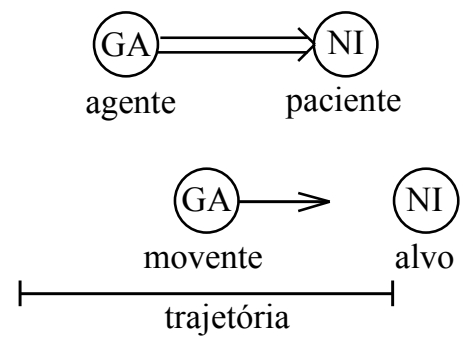

FIGURA 3: Papéis de GA e NI nos esquemas dinâmica de forças e trajetória.

\subsubsection{Ponto de partida e trajetória}

A interpretação do local marcado com WO como ponto de partida ou como trajetória pode depender da natureza semântica do verbo que descreve a ação de deslocamento.

Verbos como "sair" (deru: ver exemplo 2 acima), "partir" (shuppatsu-suru) etc. implicam na focalização do ponto inicial do deslocamento. Por seu lado, verbos como "atravessar" (wataru), "andar" (aruku) etc. desfocam o ponto inicial, chamando a atenção para a trajetória. Em ambos os casos, o local é percebido como estando dentro da área de influência do agente. Aqui, fica clara a diferença entre o local marcado com WO e o marcado com NI: um local só será marcado com NI se o verbo permitir focalizar um ponto de chegada, como no exemplo 9a.

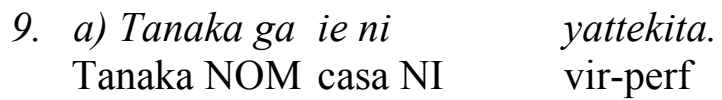

Tanaka veio à casa.

b) eki ni iku. estação NI ir Vou à estação.

c) furusato no ekiwo iku. terra natal GEN estação WO ir Vou pelas (percorro as) estações da terra natal.

Quando dizemos que a relação expressa entre o agente e o local depende da natureza do verbo, não significa que a posposição não acrescente sentido e seja apenas selecionada de 
acordo com a relação entre os constituintes já percebida pelo usuário da língua. Os exemplos 9b e 9c acima demonstram o poder das posposições de informar qual é a relação entre verbo e local que o emissor da mensagem deseja expressar, entre as possibilidades oferecidas pelo verbo $i k u$ (ir). Outros verbos também podem dar margem a diferentes interpretações que só as posposições podem identificar, como oyogu (nadar):

10. a) kurabu no pûru de oyogu. clube GEN piscina L-INS nadar Nado na piscina do clube.

b) keiko de kurabuno pûru wo oyogu. treinamento L-INS clube GEN piscina WO nadar Nado (toda) a piscina do clube no treinamento. (percorro a piscina nadando)

A projeção da imagem da área de influência da força do agente ao local de deslocamento pode ser observada através de uma análise do aspecto do movimento verbalizado (sair, percorrer, ir, chegar etc.) que cada posposição pode focalizar.

Para qualquer deslocamento que ocorra no mundo, presume-se que haja um local de partida, um trajeto e um local final. Associados a WO, verbos como deru (sair) e shuppatsusuru (partir) (ver exemplo 2 no início do capítulo), expressam movimentos que se concluem próximo ao local de partida (no ponto inicial) do deslocamento do sujeito. Outros verbos, como wataru (atravessar), tooru (passar) etc., expressam movimentos que ocorrem ao longo da trajetória. Outros verbos ainda, como tsuku (chegar), representam movimentos que ocorrem no trecho final da trajetória, e exigem o uso de NI. A Tabela 1 resume essas possibilidades. 
Tabela 1: posposições selecionadas em função do aspecto do movimento verbalizado e do trecho focalizado da trajetória (adaptada de Moriyama, 2005, p. 57)

\begin{tabular}{|l|l|c|l|}
\cline { 2 - 4 } \multicolumn{1}{c|}{} & \multicolumn{2}{c|}{} \\
\cline { 2 - 4 } & \multicolumn{3}{c|}{ aspecto do movimento no ponto focalizado } \\
\hline Posposição & no ponto inicial & ao longo da trajetória & no ponto final \\
\hline WO (ponto de partida) & iniciado & concluído & (fora de foco) \\
\hline WO (trajeto) & iniciado & em andamento & (fora de foco) \\
\hline NI (ponto de chegada) & (fora de foco) & não iniciado & iniciado \\
\hline
\end{tabular}

Em termos de influência da força do agente, podemos compreender os dados acima do seguinte modo: o uso de WO está associado à interpretação de que a parte focalizada do trajeto já sofreu, ou ainda se encontra sob, a ação do sujeito. Quando se trata de movimentos que implicam exclusivamente na focalização do final do trajeto (tsuku - chegar/grudar etc.), não se utiliza WO, restando essa função para NI. A Figura 4 ilustra essas interpretações.
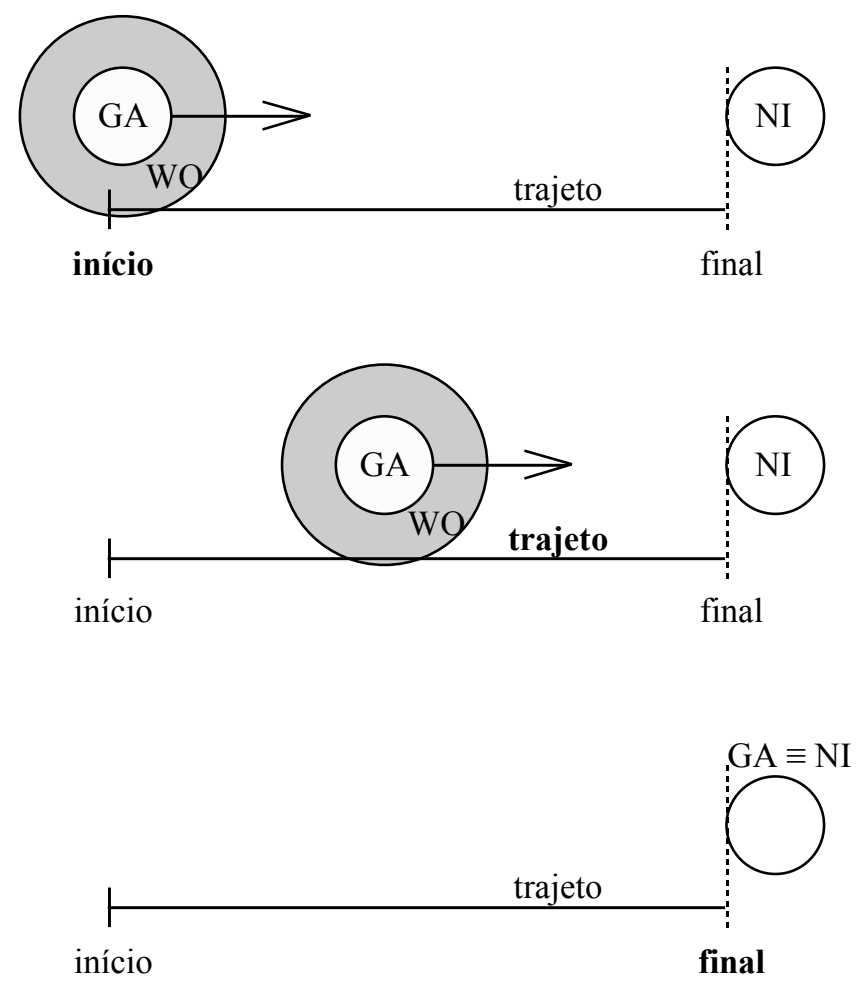

Figura 4: GA, WO, NI e o esquema de imagem trajetória. Em negrito, os elementos focalizados pelas posposições WO e NI, dependendo do verbo. 


\subsubsection{Condições}

A acepção de condições é resultado da abstração do trajeto. No exemplo 4, apresentado na introdução deste capítulo, o sujeito da cognição projeta na chuva o trajeto a ser percorrido por Taro.

O condão de atribuir a condições características de trajeto é ilustrado com mais clareza por Moriyama (2005, p. 59) através do exemplo 11 abaixo.

$\begin{array}{llll}\text { 11. gôu no } & \text { naka wo } & \text { teki to } & \text { tatakatta. } \\ \text { tempestade GEN } & \text { dentro WO inimigo COM lutar-perf. } \\ \text { Lutou com o inimigo tempestade adentro. } & \end{array}$

Tatakau (batalhar) não é um verbo de deslocamento. "Dentro da tempestade" poderia ser marcado com DE, posposição associada a local de atividade. Pelo uso de WO, entretanto, pode-se enfatizar o ato de lutar como um processo linear; mais ainda, destaca-se o avanço contra o inimigo abrindo ao mesmo tempo um caminho metafórico tempestade adentro, como se abre uma picada a facão numa floresta. O uso de DE não permitiria essa interpretação ao receptor da mensagem, uma vez que colocaria a tempestade como o fundo do cenário, diminuindo seu efeito sobre o desenrolar dos acontecimentos.

\subsubsection{Tempo}

Do mesmo modo que condições, a associação de tempo à posposição WO resulta de abstração da imagem de trajeto.

Verbos como sugosu (passar), heru (passar [por uma fase da vida]) etc. expressam ações cuja conceitualização é inseparável da noção de período de tempo. É desse modo que o tempo, nesses casos, é interpretado metaforicamente como um objeto sob ação do sujeito.

Moriyama (2005, p. 60) ainda destaca que o tempo adquire certa "materialidade" em frases como o exemplo 12. 

12. shishunkiwo hete otona ni naru puberdade WO passar-ADT adulto DAT tornar-se Passa pela puberdade e torna-se adulto.

A puberdade é uma fase necessária para que se chegue à vida adulta. Com base nisso, Moriyama (idem, ibidem) observa que é possível interpretar esse tempo metaforicamente como um trajeto, que ganha um caráter, digamos, "menos abstrato", na medida em que todo ser humano é obrigado a percorrê-lo.

\subsubsection{Resumo: a estrutura semântica de WO}

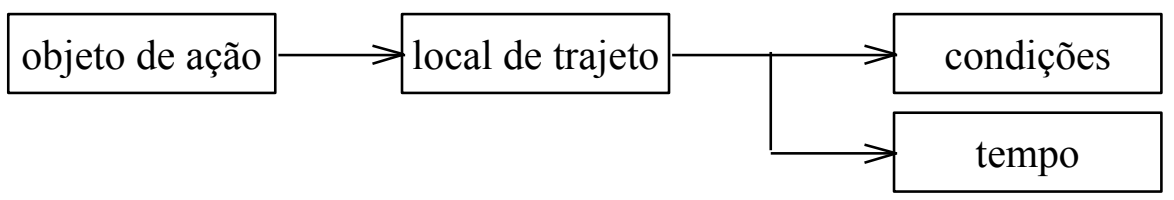

Figura 5. Representação gráfica da categoria formada sob a posposição WO

A acepção prototípica da posposição de caso WO é marcador de objeto direto, ou seja, marca o participante que está sob influência direta da força do agente, marcado com GA.

A dinâmica de forças dos casos prototípicos é projetada metaforicamente em um esquema de imagem de trajetória, permitindo a percepção de locais de trajeto como objetos da ação do sujeito. Mais ainda, a imagem do local de trajeto pode servir como referência para a interpretação de condições e períodos de tempo que podem ser "percorridos".

O traço semântico comum a todas essas acepções, ou seja, o sentido esquemático de WO, é a subordinação de um objeto à influência da ação do sujeito. 


\subsection{Mapeamento de preposições do português em WO}

A posposição de caso WO se constitui em uma estrutura semântica relativamente simples, e assim as convergências e divergências entre WO e marcadores de caso do português podem ser observadas com certa facilidade.

O sentido esquemático do objeto direto em português e japonês é o mesmo. Entretanto, alguns usos do japonês não encontram correspondente em português. Novamente, procuraremos responder aqui quais são os nexos do português que podem ser mapeados em WO.

\subsubsection{Objeto direto}

1. jûsu wo поти. suco WO beber

Bebo Ø suco.

Em português, o objeto direto é marcado pela sua posição na frase. Em casos especiais, por questão de estilo ou para evitar ambigüidade, o objeto direto recebe a preposição $a$. Para efeito de mapeamento, consideraremos que o português usa "marcador zero" (Ø) para identificar o objeto direto ${ }^{21}$.

O marcador zero pode ser mapeado em WO independentemente do nível de concretude do movimento ou do objeto descrito.

\subsubsection{Local-ponto de partida}

$\begin{array}{lll}\text { 2. a) hachi-ji ni } & \text { iewo } & \text { deru. } \\ \text { oito horas DAT } & \text { casa WO } & \text { sair }\end{array}$

Saio de casa às oito horas.

b) hachi-jini ie kara deru.

oito horas DAT casa ABL sair

Saio de casa às oito horas.

21 O sujeito em português também levaria "marcador zero"; entretanto, estando este fora do escopo da dissertação, cremos que não haja risco de confusão. 
Na língua portuguesa, não se aplica a noção de área de influência do sujeito sobre o objeto à especificação de um ponto de partida de deslocamento. Isto é, o usuário do português não reconhece uma dinâmica de forças entre o sujeito e o local de partida, pelo menos quando deslocamento for parte do sentido prototípico do verbo. Por exemplo, a construção "deixo minha casa às oito horas" não pode ser considerada análoga ao exemplo $2 \mathrm{a}$, pois o verbo deixar não contém o ato de deslocar-se em sua acepção prototípica.

Considerando as dificuldades que o aprendiz lusófono pode encontrar para assimilar este uso de WO, devemos lembrar que o ponto de partida em japonês também pode ser marcado com a posposição de caso KARA (ablativo), que nesta acepção é normalmente associada à preposição de.

Acontece que KARA difere de WO por marcar um ponto de partida com foco fora da influência da ação do sujeito. Por isso, construções como $2 \mathrm{~b}$ são consideradas pouco naturais em japonês.

Em suma, o português não permite o uso do mesmo marcador para objeto direto e ponto de partida, ou seja, não há mapeamento possível de um marcador do português em WO neste caso. O aprendiz lusófono tem de assimilar conscientemente esse uso de WO, para evitar a tendência ao uso indiscriminado de KARA em decorrência da analogia desta posposição com de.

\subsubsection{Local-trajeto}

3. a) ôdoori wo wataru. avenida WO atravessar *atravesso pela avenida Atravesso Ø a avenida.

b) ôdoori wo tootte machi wo wataru. avenida WO passar-ADT cidade WO atravessar Atravesso a cidade pela avenida ( $<$ Atravesso a cidade passando pela avenida). 


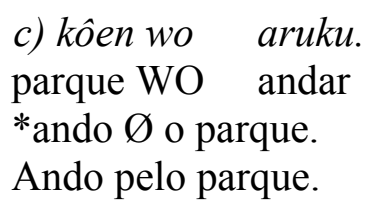

Quando se trata de focalizar a parte principal do trajeto, vários verbos de deslocamento do português, como atravessar, percorrer, escalar, etc. aceitam o marcador zero. Vários outros, porém, o rejeitam: andar, correr, nadar etc. A diferença entre esses dois grupos de verbos é que o primeiro está relacionado a trajetórias determinadas, ou seja, com início e final definidos. Para que o segundo grupo aceite o marcador zero, é necessário um contexto que permita interpretar que o deslocamento completou uma trajetória determinada, como em "andei o parque todo à sua procura". Ainda assim, esse uso não é totalmente aceito na variante culta do português, em que se prefere "andei pelo parque todo".

Cabe observar ainda, como demonstra o exemplo 4a, que expressões de cumprimento de trajetórias determinadas rejeitam por. O exemplo $4 \mathrm{~b}$ demonstra que por, em português, distingue a trajetória cumprida do meio usado para cumpri-la. Essa distinção não se verifica quando não se tratar de trajetórias determinadas (exemplo 4c).

Em suma, na acepção de local de trajeto, o marcador zero só pode ser mapeado em WO a partir de construções com verbos que expressam trajetórias determinadas. Outros verbos de deslocamento em português pedirão a preposição por. Para efeito de mapeamento pelo aprendiz lusófono, tanto o marcador zero (Ø) como a preposição por podem ser associados a WO.

\subsubsection{Condições}

4. Tarôga ameno nakawo iku.

Taro NOM chuva GEN dentro WO ir

?Taro vai $\varnothing$ dentro da chuva.

?Taro vai pela chuva.

Taro vai chuva adentro. 
Para uma tradução mais aceitável do exemplo 4, empregamos o advérbio adentro, obtendo, ainda assim, uma construção pouco usual. Mesmo a frase original em japonês representa uma combinação de uso restrito. Levantamos alguns números para embasar nossas observações.

Buscamos no Google Japan o número de ocorrências em sítios da internet da seqüência wo iku e obtivemos cerca de 1.760 .000 resultados. Destes, a combinação michi wo $i k u$ ("ir pelo caminho") responde por cerca de 1.030.000 ocorrências, ou seja, algo como 60\% do total. Já ame no naka wo iku (?ir por dentro da/pela chuva) apresenta apenas 4.960 ocorrências, ou $0,003 \%$ do total. Além de ame (chuva), outros elementos também podem ser apontados como condições sob as quais se realiza a ação iku (ir): yuki (neve), kaze (vento), kunô (aflição), jûtai (congestionamento de trânsito) etc. Nenhum deles ocorre junto de wo iku em maior número que ame. Como era de se esperar, o número de ocorrências cai à medida que o elemento é "menos concreto": o complemento kunô (aflição), por exemplo, apareceu apenas 394 vezes (10 vezes menos que ame-chuva).

Repetimos o procedimento com seqüências em português correspondentes às do japonês. A combinação ir por foi substituída por andar pelo e andar pela, para evitar a ambigüidade entre por como marcador de meio ou de trajeto. A seqüência andar pelo apareceu com 66.900 ocorrências, e andar pela, com 84.700, num total de 151.600 ocorrências. Andar pela chuva resultou em 10 ocorrências $(0,007 \%$ do total), e andar pela neve, em 30 ocorrências (0,021\%). Para andar pelo vento não houve ocorrência; com neblina, tivemos apenas 1 ocorrência $(0,0007 \%)$. Elementos mais abstratos que isso não são percebidos como "caminhos" pelos usuários do português. Resumindo, a metáfora "condições são caminhos" em português é rara a ponto de se poder questionar a aceitabilidade de frases 
que a apliquem.

Não afirmaremos categoricamente que o uso de WO para marcar condições não encontra correspondente no português, mas cremos que esteja evidente que o aprendiz lusófono precisará de um esforço consciente para assimilá-lo.

\subsubsection{Tempo}

5. a) natsuyasumi wo Okinawa de sugosu. férias de verão WO Okinawa L-INS passar *passo pelas férias de verão em Okinawa. Passo as férias de verão em Okinawa.

$\begin{array}{lll}\text { b) shishunki wo } & \text { hete } \quad \text { otona ni } & \text { naru } \\ \text { puberdade WO } & \text { passar-ADT adulto DAT } & \text { tornar-se } \\ \text { *passar a puberdade e tornar-se adulto. } & \\ \text { Passar pela puberdade e tornar-se adulto. } & \end{array}$

A diferença entre as traduções possíveis para $5 \mathrm{a}$ e $5 \mathrm{~b}$ mostra que o português faz alguma distinção entre os tempos expressos nesses exemplos.

Relembramos que o exemplo 5b faz referência a uma fase, pela qual é necessário que se passe para se atingir um resultado, estágio evolutivo etc. Nesse sentido, uma fase pode ser entendida como uma imposição, sobre a qual a influência do sujeito é fraca. Sem a conotação de fase, é mais fácil admitir que o tempo esteja sob o controle do sujeito. Pode estar aí a distinção feita em português que não aparece no japonês.

Em suma, o marcador zero pode ser associado a WO para tempo se este for percebido como sob controle do sujeito. A conotação de fase exigirá por. O aprendiz pode ignorar essa distinção para assimilar este uso de WO, mapeando Ø ou por em NI.

\subsubsection{Resumo: mapeamento de marcadores em WO}

O mapeamento de marcadores do português em WO é impedido nas acepções que envolvem projeções metafóricas mais complexas. No caso de local de partida, o usuário do 
japonês aceita um esquema que associa a energia do agente a um ponto do qual ele se afasta; no caso das condições, o usuário projeta uma trajetória em um ente amorfo. Essas conceitualizações não são encontradas na língua portuguesa.

Por outro lado, as acepções que envolvem o esquema de imagem TRAJETÓRIA e ao mesmo tempo uma ação direta do sujeito sobre o trajeto, como é o caso de local de trajeto e tempo, permitem mapear o marcador zero ou a preposição por. Como "efeito colateral" de nossas investigações, percebemos que $\varnothing$ e por são usados em distribuição complementar dentro de cada uma das duas acepções.

Tabela 2. Mapeamentos possíveis de marcadores do português em WO

\begin{tabular}{|c|c|c|c|c|}
\hline objeto direto & local de partida & local de trajeto & tempo & condições \\
\hline$\varnothing$ & $\mathrm{x}$ & $\varnothing /$ por & $\mathrm{x}$ \\
\hline
\end{tabular}




\section{Conclusões}

Neste trabalho, estudamos as estruturas semânticas das posposições de caso NI, DE e WO do japonês e investigamos como e quais das variadas acepções de cada uma delas podem ser expressas através de preposições do português. Com isso, pudemos estabelecer com razoável nitidez até que ponto vão as semelhanças entre as posposições estudadas e as preposições do português a que podem ser associadas. Neste capítulo, apresenta-se o que aprendemos com as informações e análises vistas até aqui.

\subsection{Estruturas semânticas, mapeamento e aquisição / aprendizagem}

De acordo com a semântica cognitiva, o ser humano, antes de adquirir a linguagem, conta com um dispositivo de cognição que permite captar os elementos percebidos à sua volta e estabelecer relações, interagindo com o ambiente desde o nascimento. Segundo esse raciocínio, durante as primeiras fases da aquisição da linguagem, o sujeito da cognição vai associando à linguagem verbal primeiramente os elementos perceptíveis sensorialmente, e depois aqueles que dependem do raciocínio. Em uma fase mais adiantada é que aprendemos a verbalizar conceitos complexos, e o fazemos através de metáforas, modelando esses conceitos nas formas daqueles que assimilamos nas fases anteriores.

Se a teoria estiver correta, os desenhos das estruturas semânticas, que ordenam as acepções dos vocábulos colocando no centro os sentidos diretamente perceptíveis e na periferia os abstratos e metafóricos, devem representar com razoável fidelidade o processo de aquisição dos recursos lingüísticos pelos usuários nativos.

Diante da complexidade semântica das pospoições, certamente será benéfica aos aprendizes não-nativos a exposição das acepções de cada uma delas através desse ordenamento mais natural. Moriyama (2005) apresenta os primeiros resultados de 
experiências com estudantes chineses e coreanos sobre a aquisição de posposições do japonês, e já demonstrou com números que os aprendizes assimilam os usos de DE em uma ordem coerente com o que postula a semântica cognitiva.

Contudo, nossa iniciativa de levantar mapeamentos de preposições do português em posposições do japonês surgiu da intuição de uma hipótese: mesmo que se exponham os usos dos nexos japoneses na ordem em que provavelmente os usuários nativos os adquirem, pode haver interferências do sistema de nexos já incorporado pelo aprendiz lusófono.

Uma dessas interferências é que, mesmo nos usos centrais de certas posposições, a relação com preposições não é consistente. Por exemplo, pode-se associar para a NI como marcador de alvo de movimento, mas apenas se a ação for transitiva. Se não for, o aprendiz terá de se lembrar que algumas ações, que são expressas em português com verbos que regem com ou são transitivos diretos, serão ditas em japonês com verbos que regem NI. Se não, tenderá a produzir a sentença usando TO ou WO, posposições cujos sentidos prototípicos são os mesmos de com e do marcador zero, respectivamente, gerando sentenças agramaticais em japonês.

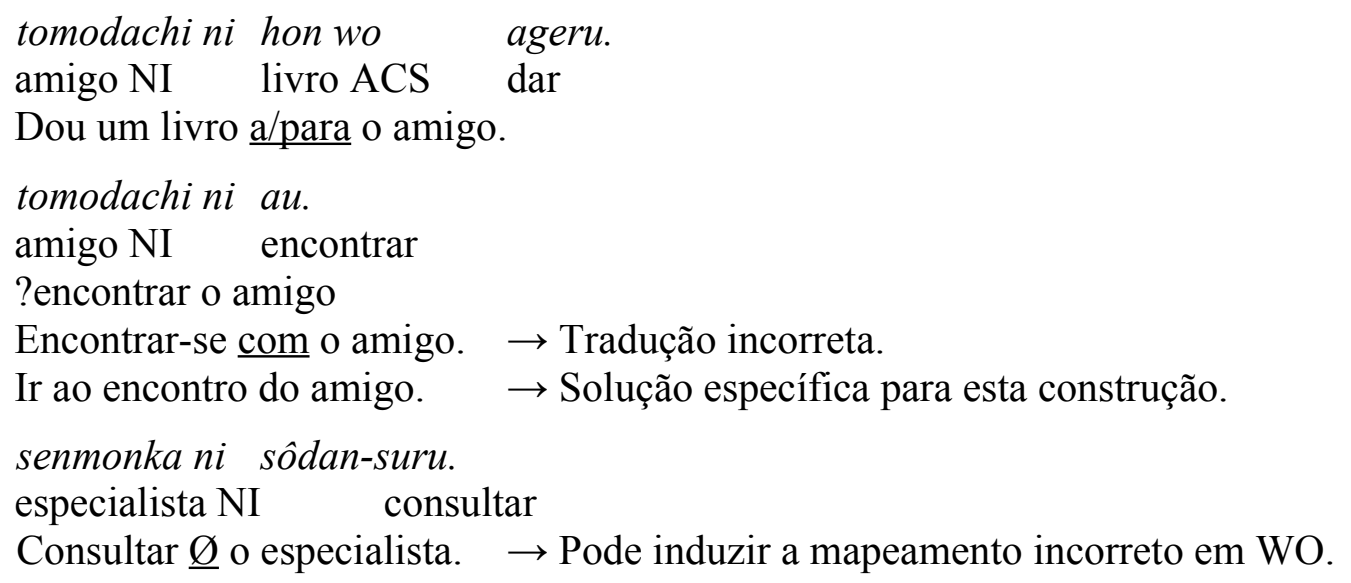

Outra interferência é a de que alguns usos das preposições japonesas representam interpretações cognitivas simplesmente inexistentes no português, da mesma forma que, por 
exemplo, a noção expressa pelo infinitivo pessoal do português não existe no japonês. Em português não há como expressar a relação de posse entre uma pessoa e um objeto em termos do esquema de imagem CONTINENTE-CONTEÚDO.

watashini kodomoga aru.
eu NI filhos NOM há
*em mim há filhos
Eu tenho filhos.

A verificação desses fatos, registrados ao longo desta dissertação, tende a confirmar nossa hipótese. Seria interessante, em uma próxima etapa, levantar estatísticas sobre a assimilação de posposições japonesas por aprendizes lusófonos para uma confirmação definitiva.

\subsection{As diferenças entre NI, DE e WO como marcadores de local}

O estudo das estruturas semânticas de NI, DE e WO permite distinguir seus sentidos essenciais e, por extensão, os sentidos de seus usos como marcadores de local. Adicionalmente, a investigação dos mapeamentos possíveis de preposições do português nessas posposições deverá auxiliar na abordagem desses marcadores para assimilação pelo aprendiz lusófono.

Tradicionalmente, nos cursos de japonês aprende-se a marcar local primeiro com NI, depois com DE e finalmente com WO. O aprendiz lusófono tende a marcar local com NI indiscriminadamente mesmo após conhecer DE; depois de assimilar DE, e ao conhecer WO, muitas vezes fica em dúvida entre esses dois últimos. Desse modo, cremos que as comparações mais pertinentes a problemas com marcação de local sejam entre NI e DE e entre DE e WO. 


\subsubsection{NI e DE}

A confusão entre NI e DE está localizada especificamente no cruzamento entre a acepção prototípica da perspectiva ontológica de NI, ou seja, local de existência, com a acepção prototípica de DE, local de evento. Podemos afirmar que o sentido de NI nessa acepção é o mesmo que o sentido prototípico de $\mathrm{em}$, mas não podemos associar, estritamente falando, DE a nenhuma preposição.

O local marcado com NI faz parte do primeiro plano do cenário, é o continente que envolve o objeto observado. O local marcado com DE está em segundo plano no cenário, e tem uma função em relação aos participantes: propiciar condições para a realização da ação.

O português não dispõe de uma preposição específica para distinguir o fundo dos participantes no cenário percebido ${ }^{22}$. Desse modo, enquanto o aprendiz não assimilar o conceito de fundo para um evento, não poderá utilizar DE naturalmente.

\subsubsection{DE e WO}

Logo após entender que DE marca locais onde ocorrem eventos, o aprendiz tenderá a ligar quaisquer eventos com quaisquer locais por meio dessa posposição.

O local marcado com DE é desfocado com relação ao evento. Já o local marcado com WO está sob influência direta da força do agente, o que permite a projeção da imagem de DINÂMICA DE FORÇAS no esquema de TRAJETÓRIA.

Em português um trajeto só é expresso como objeto direto se for completamente inserido no domínio do sujeito. Por exemplo, escalar a montanha significa conquistá-la, indo até o topo. Se um alpinista não chegou ao cume de determinada montanha, não tende a dizer que a escalou.

\footnotetext{
22 Não queremos dizer que não o possa fazer por meio de outros recursos lingüísticos.
} 
Deslocamentos sem um destino definido, em português, tendem a receber a mesma classificação que outras atividades quaisquer, e assim, são localizados com em ("ando no parque", "corro na praia" etc.). Classificadas desse modo, essas atividades tendem a ser associadas a DE pelo aprendiz que já conhece essa posposição. Cumpre, portanto, conscientizar essa diferença para "reclassificar" essas atividades e marcá-las com a posposição correta.

\subsubsection{Considerações finais}

Neste trabalho, concentramo-nos em um grupo pequeno de posposições, delimitado por um critério prático (a questão dos locativos), mas com uma abordagem essencialmente teórica. Como dissemos alguns parágrafos acima, seria interessante confrontar estas colocações com dados empíricos, analisando-se o processo de aquisição das posposições japonesas por aprendizes lusófonos na prática.

Apesar de focalizar predominantemente a língua japonesa, cremos que as comparações aqui contidas possam trazer pistas também sobre a semântica das preposições do português, sobre as quais não temos conhecimento de descrições semânticas extensas como as que Moriyama (2005) faz das posposições japonesas.

Enfim, esperamos ter dado alguma contribuição para a prática do ensino e da tradução da língua japonesa para usuários do português, e, indiretamente, para japoneses interessados em nossa língua. 


\section{Bibliografia}

ALFONSO, A. (1974). Japanese Language Patterns, Tokyo: University of Sofia.

CASTILHO, A. (2004). Proposta funcionalista de mudança lingüística. Disponível em: $<$ http://www.fflch.usp.br/dlcv/lport/ATCastilho001.pdf>

CATARINO, J. C. e PINTO, C. (2004). Em torno de preposições causativas. Publicação do site Priberam. Disponível em: <www.priberam.pt/docs/PrepsCausativas.pdf >. Acesso: 03/12/2006.

FUKASAWA, L., GIROUX, S., SUZUKI, Tae, SUZUKI, Teiiti (2001). Introdução à gramática da língua japonesa. São Paulo: Centro de Estudos Japoneses da USP.

HEBECHE, L. (2005). Não pense, veja! - sobre a noção de "semelhanças de família" em Wittgenstein. Disponível em: <http://www.cfh.ufsc.br/ wfil/veja.pdf> Acesso em $30 / 08 / 2006$.

HOUAISS, A. (2001). Dicionário Houaiss da Língua Portuguesa. Versão eletrônica. Disponível em $<$ http://houaiss.uol.com.br/busca.jhtm $>$.

KATO, M. (1989). Sujeito e tópico: duas categorias em sintaxe? In: Cadernos de Estudos Lingüísticos, 17, pp. 109-132.

KOKUBO, N. (2004). Novo curso básico de japonês. 4a. ed. São Paulo: Aliança Cultural Brasil-Japão.

KRISTOFFERSEN, K. E. (2001). Semantic Structure of the Norwegian preposition mot. Nordic Journal of Linguistics. No. 24, pp. 3-28.

KUNO, S. (1980). Nihon Bunpô Kenkyû (Pesquisa da língua japonesa). 7 ed. Tokyo: Taishûkan.

LAKOFF, G. (1987). Women, fire and dangerous things: what categories reveal about the mind. Chicago: Chicago University Press.

LAKOFF, G.; JOHNSON, M. (1995). Metaforas de la vida cotidiana. Tradução de Carmen González Marín. Madri: Cátedra. Título original: Metaphors we live by.

LAKOFF, G.; JOHNSON, M. (1999). Philosophy in the Flesh. The Embodied Mind and its Challenge to Western Thought. New York, Basic Books.

LANGACKER, R.W. (1991a). Foundations of Cognitive Grammar. Vol.2. Stanford: Stanford University Press.

(1991b). Concept, Image, and Symbol: The Cognitive Bases of Grammar. Berlim: Mouton de Gruyter. 
(2000). Grammar and Conceptualization. Berlim: Mouton de Gruyter.

LEMOS, E. (2005). Análise do morfema kara sob a perspectiva multissistêmica. In: ENCONTRO NACIONAL DE PROFESSORES DE LÍNGUA, LITERATURA E CULTURA JAPONESA, 16, Brasília, 2005. Anais: Estudos japoneses e intercâmbio acadêmico internacional. Brasília: UnB, pp. 339-347.

(2006). Análise semântica do morfema NI da língua japonesa. In: ENCONTRO NACIONAL DE PROFESSORES DE LÍNGUA, LITERATURA E CULTURA JAPONESA, 17, São Paulo, 2006. Anais: O Japão em múltiplas abordagens. São Paulo: EDUSP. No prelo.

MABUCHI, Y. (2000). Kakujoshi DE no imi kakuchô ni kan-suru hito kôsatsu (uma pesquisa sobre as extensões semânticas da posposição de caso DE). In: Kokugogaku, vol.51, n. 1 Tokyo: Kokugo Gakkai, pp. 15-30.

MAKINO, S e TSUTSUI, M. (2000). A dictionary of basic japanese grammar. 16 ed. Tokyo: The Japan Times.

MATSUMURA, A. (1999, ed.). Daijirin. 2 ed. Tokyo: Sanseido.

MORIYAMA, S. (2003). Ninchiteki kanten kara mita kakujoshi NI no imi kouzou (A estrutura semântica da posposição de caso NI, de uma perspectiva cognitiva). In: Gaikokugo Kyôiku Gakkai. Tokyo: vol. 10, n. 1, pp. 229-243

(2005). Ninchigengogakuteki kanten wo toriireta kakujoshi no imi no nettowâku kôzô kaimei to sono shûtoku katei (Descrição da estrutura semântica em rede das posposições de caso e seus processos de aprendizagem, da perspectiva da semântica cognitiva). Relatório de pesquisa para o Ministério da Cultura, Esportes, Ciência e Tecnologia do Japão. Disponível em: $<$ http://jslserver.li.ocha.ac.jp/morishin1003/kaken.pdf>

MUKAI, Y. (2004). As funções dos morfemas "wa"e "ga" na língua japonesa moderna: uma análise lingüística (morfossintática e pragmática) e de erros. In: ENCONTRO NACIONAL DE PROFESSORES DE LÍNGUA, LITERATURA E CULTURA JAPONESA, 15, Rio de Janeiro, 2004. Anais: Língua japonesa: teoria e prática. Rio de Janeiro: UFRJ, pp. 66-81.

NITOGURI, S. (2004). Nihongo no tokuchô - joshi no aidea, jodôshi no aidea (Características da língua japonesa: a idéia de posposição, a idéia de auxiliar). In: ENCONTRO NACIONAL DE PROFESSORES DE LÍNGUA, LITERATURA E CULTURA 
JAPONESA, 15, Rio de Janeiro, 2004. Anais: Língua japonesa: teoria e prática. Rio de Janeiro: UFRJ, pp. 38-53.

OYAMA, T. et alii (2005). Nihongo Nyûmon - Curso de Língua Japonesa para Brasileiros, Curitiba: Curso de Línguas Estrangeiras Oyama.

SAJI, K., FUKUSHIMA, Y. (orgs.) (2000). Ruiji hyôgen no tsukaiwake to shidôhô (Distinção de uso e modo de ensino de expressões com sentidos semelhantes). Tokyo: ALC

SHINMURA, I. (1999, org.). Kôjien. 5a. ed. Tokyo: Iwanami Shoten.

SUGAI, M. (2001). Gendai nihongo ni okeru kaku no zanteiteki taikeika (Tentativa de estruturação dos casos no japonês moderno). In: Gengo hyôgen kenkŷ̂ n. 17. Kôbe: Kôbe Kyôiku Daigaku Gengo Hyôgen Gakkai.

SUZUKI, K. e HAYASHI, O. (1985, orgs.). Kenkŷ̂ Shiryô Nihon Bunpô (Gramática japonesa em dados de pesquisas). Tokyo: Meiji Shoin.

TAKAHASHI, T. et alii. (2003). Nihongo no Bunpô (Gramática do Japonês). Okinawa: Kaizan Bunka Kenkyûjo.

TERAMURA, H. (1982). Nihongo no Shintakusu to Imi I (Sintaxe e semântica do Japonês I). Tokyo: Kuroshio.

WIERZBICKA, A. (1996). Semantics - primes and universals. Oxford: Oxford University Press.

WITTGENSTEIN, L. (1953). Philosophical Investigations. Tradução de G. E. M. Anscombe. New York: The Macmillan Company

YAMADA, Y. (1954). Nihon Bunpô Kôgi (Curso de gramática do japonês). 4 ed. Tokyo: Hôbunkan.

YOSHIKAWA, M. (2002). "De", "Ni" e "O" como indicativos de lugar. In: ENCONTRO NACIONAL DE PROFESSORES DE LÍNGUA, LITERATURA E CULTURA JAPONESA, 13, São Paulo, 2002. Anais: Estudos japoneses desde o pós-guerra. São Paulo: EDUSP, pp. 183-190. 